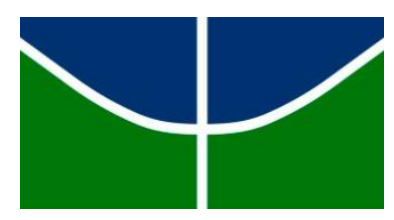

UNIVERSIDADE DE BRASÍLIA - UnB

INSTITUTO DE LETRAS - IL

DEPARTAMENTO DE LÍNGUAS ESTRANGEIRAS E TRADUÇÃO - LET

PROGRAMA DE PÓS-GRADUAÇÃO EM ESTUDOS DA TRADUÇÃO - POSTRAD

\title{
ARYON RODRIGUES: RESTAURAÇÃO E TRADUÇÃO PARA O CONHECIMENTO DA \\ LÍNGUA BRASÍLICA
}

JANAÍNA THAYONARA GIL CESAR

Brasília

Dezembro/2016 
UNIVERSIDADE DE BRASÍLIA - UnB

INSTITUTO DE LETRAS - IL

DEPARTAMENTO DE LÍNGUAS ESTRANGEIRAS E TRADUÇÃO - LET

PROGRAMA DE PÓS-GRADUAÇÃO EM ESTUDOS DA TRADUÇÃO - POSTRAD

ARYON RODRIGUES: RESTAURAÇÃO E TRADUÇÃO PARA O CONHECIMENTO DA LÍNGUA BRASÍLICA

JANAÍNA THAYONARA GIL CESAR

ORIENTADORA: PROFA. DRA. ANA HELENA ROSSI

DISSERTAÇÃO DE MESTRADO EM ESTUDOS DA TRADUÇÃO

Brasília

Dezembro/2016

UNIVERSIDADE DE BRASÍLIA - UnB 


\section{REFERÊNCIA BIBLIOGRÁFICA E CATALOGAÇÃO}

CESAR, Janaína T. G.. Aryon Rodrigues: restauração e tradução para o conhecimento da

Língua Brasílica. 2016. 127 f. Dissertação (Mestrado) - Programa de Pós-Graduação em Estudos da Tradução, Departamento de Línguas Estrangeiras e Tradução, Universidade de Brasília, Brasília, 2016.

Documento formal, autorizando reprodução desta dissertação de mestrado para empréstimo, exclusivamente para fins acadêmicos, foi passado pelo autor à Universidade de Brasília e acha-se arquivado na Secretaria do Programa. O autor reserva para si os outros direitos autorais, de publicação. Nenhuma parte desta dissertação de mestrado pode ser reproduzida sem a autorização por escrito do autor. Citações são estimuladas, desde que citada a fonte.

\section{FICHA CATALOGRÁFICA}

Cesar, Janaína Thayonara Gil

CC421a

Aryon Rodrigues: restauração e tradução para o conhecimento da Língua Brasílica / Janaína Thayonara Gil Cesar; orientador Ana Helena Rossi. -- Brasília, 2016.

$127 \mathrm{p}$.

Dissertação (Mestrado - Mestrado em Estudos de Tradução) -- Universidade de Brasília, 2016.

1. Aryon Rodrigues. 2. Jean de Léry. 3. Colóquio . 4. Crítica de Traduções. 5. 
INSTITUTO DE LETRAS - IL

DEPARTAMENTO DE LÍNGUAS ESTRANGEIRAS E TRADUÇÃO - LET

PROGRAMA DE PÓS-GRADUAÇÃO EM ESTUDOS DA TRADUÇÃ̃O - POSTRAD

\section{ARYON RODRIGUES: RESTAURAÇÃO E TRADUÇÃO PARA O CONHECIMENTO DA LÍNGUA BRASÍLICA}

JANAÍNA THAYONARA GIL CESAR

DISSERTAÇÃO DE MESTRADO SUBMETIDA AO PROGRAMA DE PÓS-GRADUAÇÃO EM ESTUDOS DA TRADUÇÃO, COMO PARTE DOS REQUISITOS NECESSÁRIOS À OBTENÇÃO DO GRAU DE MESTRE EM ESTUDOS DA TRADUÇÃO.

APROVADA POR:

Ana Helena Rossi, Dra. (Universidade de Brasília - UnB)

(Orientadora)

René Gottlieb Strehler, Dr. (Universidade de Brasília - UnB)

(Examinador interno)

Wilmar Da Rocha D'Angelis, Dr. (Universidade Estadual de Campinas - UNICAMP)

(Examinador externo)

Enrique Huelva Unternbäumen, Dr. (Universidade de Brasília - UnB)

(Suplente)

BRASÍLIA, 15 DE DEZEMBRO DE 2016. 
Aos meus pais, Edson e Jeamary.

À minha irmã, Milena, e ao meu amor, Wallace.

Dedico a vocês todo meu amor, gratidão e admiração. 


\section{AGRADECIMENTOS}

Antes de tudo, o meu agradecimento a Deus que me deu o sopro da vida e me sustentou nos momentos mais difíceis, quando achei que não tinha mais forças para me levantar.

O meu eterno agradecimento aos meus pais, que me garantiram as condições para conquistar tudo o que já conquistei e o que ainda vou conquistar nesta vida. Obrigada pela paciência e pelos ensinamentos.

Agradeço ao meu amor, Wallace, por todos os momentos em que me ajudou a concretizar este sonho, por todas as palavras de carinho e encorajamento.

Agradeço a minha irmã, Milena, pelo carinho e por ter me ajudado na revisão do trabalho.

Agradeço às Benjaminianas por todo o apoio e por tornar as minhas sextas-feiras muito mais produtivas.

Agradeço às minhas amigas pelos mimos atenciosos e chocolates nos momentos mais tensos deste semestre, e por sempre me dizerem palavras encorajadoras e carinhosas. Espero um dia poder retribuir todo este carinho.

Agradeço imensamente à minha orientadora, Ana Helena Rossi, pela paciência, apoio intelectual e emocional. Por ter acreditado em mim e na minha pesquisa. Agradeço, principalmente, por me apresentar à reflexão sobre o processo tradutório, por me envolver nos enriquecedores projetos de iniciação científica e nas discussões do grupo de pesquisa, que muitas vezes me ensinaram mais do que eu poderia aprender durante todo um curso. Muito obrigada mesmo. Nunca vou esquecer o que a sra. fez por mim.

Por fim, agradeço à Coordenação de Aperfeiçoamento Pessoal de Ensino Superior (CAPES) pelo suporte financeiro que permitiu a minha dedicação exclusiva à realização desta pesquisa. 
oré rúb ybákype tekwár imoetépyramo ne réra t oikó.

Tupinambá (1618) 


\section{RESUMO}

A obra do missionário calvinista Jean de Léry (1536-1613), intitulada: História de uma viagem feita à terra do Brasil, editada em 1580, destaca-se entre as literaturas de viagem do século XVI como precursora dos estudos etnográficos nos idos do Brasil Colônia. Sua importância é acentuada pelo conhecimento da língua, cultura, história e religião do Novo Mundo. Estas características podem ser observadas no capítulo XX, Colóquio entre as gentes do país, restaurado e retraduzido pelo linguista e pesquisador de línguas indígenas, Aryon Rodrigues. Objeto de estudo desta pesquisa, este capítulo possui um valor documental histórico e linguístico sobre a realia do índios Tupinambá do século XVI. Este Colóquio é composto por 212 diálogos que tratam da recepção de um viajante francês por um anfitrião indígena no aldeamento dos índios Tupinambá. Estes diálogos incluem frases de comunicação do cotidiano do aldeamento, observações gramaticais sobre pronomes e verbos, nomes de animais, plantas e objetos culturais. De acordo com Aryon Rodrigues, estas observações formam o primeiro ensaio publicado sobre os aspectos gramaticais de uma língua indígena brasileira, a língua dos índios Tupinambá. A problemática que envolve nossa pesquisa permeia o locus da alteridade do índio Tupinambá no âmbito da conversão linguística da língua Tupinambá, da passagem da oralidade à escrita ocidental. Esta problemática será tratada a partir dos estudos de Frank Lestringant, Michel de Certeau e Mattoso Câmara. Estudaremos a escrita da língua Tupinambá e a tradução da língua francesa a partir das publicações brasileiras do Colóquio na perspectiva da retradução por W. Benjamin, A. Berman e Yves Gambier, e os incluiremos na crítica produtiva proposta por A. Berman. Também trataremos do projeto etnolinguístico de Aryon Rodrigues para o Colóquio, publicado em 2009, onde ele realiza quatro operações plurilíngues no âmbito de uma proposta de restauração da língua Tupinambá, partindo da metodologia da linguística descritiva e do método da tradução literal que convergem para a elaboração de conhecimentos sobre a línguacultura de uma nação que não possui mais falantes. Esta pesquisa estuda o projeto de retradução de Aryon Rodrigues que altera a mudança de visão do mundo indígena, nos proporcionando conhecer os aspectos sociais e culturais presentes no século XVI.

PALAVRAS-CHAVES: Colóquio, Jean de Léry, Aryon Rodrigues, Retradução, Crítica de Traduções, Etnolinguística, operações plurilíngues. 


\section{RÉSUMÉ}

Le travail du calviniste missionnaire Jean de Léry (1536-1613) intitulé Histoire d'un voyage fait à la terre au Brésil, édité en 1580, est parmi la littérature de voyage du XVIe siècle un texte précurseur des études ethnographiques sur la période du début de l'histoire du Brésil. L'importance de cette oeuvre s'explique par la connaissance de la langue, la culture, l'histoire et la religion du Nouveau Monde. Ces caractéristiques peuvent être observées dans le chapitre XXe intitulé Colloque entre les gens du pays, publié en 2009, qui a été restauré et retraduit par le linguiste et chercheur des langues autochtones, Aryon Rodrigues. Ce chapitre, objet d'étude de cette recherche, a une valeur documentaire historique et linguistique à propos du Realia des Indiens Tupinambá du XVI ${ }^{\mathrm{e}}$ siècle. Ce Colloque se compose de 212 dialogues qui traitent de la réception d'un voyageur français par un hôte indigène dans la tribu des Indiens Tupinambá. Ces dialogues comprennent les phrases utilisées dans la communication journalière des Indiens, les commentaires grammaticaux sur les pronoms et les verbes, les noms des animaux, des plantes et des éléments culturels. Selon Aryon Rodrigues, ces observations constituent le premier essai publié sur les aspects grammaticaux d'une langue autochtone du Brésil. La problématique de notre recherche consiste à discuter le locus de l'altérité de l'Indien Tupinambá dans le cadre de la conversion linguistique de langue Tupinambá, du passage de l'oralité à l'écriture occidentale. Cette problématique sera traitée à partir des études de Frank Lestringant, Michel de Certeau et Mattoso Câmara. Nous étudierons ce genre d'écriture dans les traductions brésiliennes du Colloque au vu de la retraduction de W. Benjamin, A. Berman et Yves Gambier. Nous nous incluerons dans la critique productive proposée par A. Berman en mettant en évidence le projet ethnolinguistique de Aryon Rodrigues pour le Colloque où il réalise quatre opérations plurilingues dans le cadre d'une proposition de restauration de la langue Tupinambá à partir de la méthodologie de la linguistique descriptive et de la méthode de traduction littérale qui convergent sur l'élaboration de la connaissance sur la langue-culture d'une nation qui n'a pas plus de locuteurs. Cette recherche étudie le projet de retraduction de Aryon Rodrigues à propos du changement de la vision du monde autochtone. Ce qui nous apporte la possibilité de connaître les aspects sociaux et culturels présents dans le XVIe siècle.

MOTS-CLES: Colloque, Jean de Léry, Aryon Rodrigues, Retraduction, Critique des traductions, Ethnolinguistique, opérations plurilingues. 


\section{SUMÁRIO}

DEDICATÓRIA

$\mathrm{v}$

AGRADECIMENTOS

vi

EPÍGRAFE

vii

RESUMO

viii

RÉSUMÉ

ix

ÍNDICE DE FIGURAS E TABELAS

INTRODUÇÃO

PROBLEMÁTICA

OBJETIVOS

JUSTIFICATIVA

CONTEÚDO

CAPÍTULO 1.

JEAN DE LÉRY: O HUGUENOTE E A ESCRITA DA HISTÓRIA

1.1 JEAN DE LÉRY: MISSIONÁRIO CALVINISTA NO BRASIL

1.2 TRUCHEMENTS E LÍNGUAS: OS INTÉRPRETES NO BRASIL COLÔNIA

CAPÍTULO 2.

RETRADUÇÃ̃O: O LOCUS DO POSICIONAMENTO CRÍTICO

2.1 RETRADUÇÃO E CRÍTICA

2.2 CRÍTICA PRODUTIVA: TRADUÇÕES BRASILEIRAS DO COLÓQUIO 54

2.2.1 Batista Caetano (1876)

2.2.2 Tristão Alencar Araripe (1889)

2.2.3 Monteiro Lobato (1926)

2.2.4 Plínio Ayrosa (1941)

66

2.3 POR QUE RETRADUZIR?

CAPÍTULO 3.

AS OPERAÇÕES PLURILÍNGUES DE ARYON RODRIGUES PARA UM 74 CONHECIMENTO LINGUÍSTICO

3.1 OS ESTUDOS LINGUÍSTICOS DE ARYON RODRIGUES

3.2 PROJETO ETNOLINGUÍSTICO DE RESTAURAÇÃO DA LÍNGUA 79

BRASÍLICA 


\title{
ÍNDICE DE FIGURAS E TABELAS
}

\author{
LISTA DE FIGURAS
}

Figura 1 - Diagrama da tradução francesa do Colóquio (1580) 33

Figura 2 - Gráfico de representação dos tempos verbais da tradução francesa do 37 Colóquio (1580)

Figura 3 - Gráfico de representação dos tempos verbais na tradução do Tupinambá 40 restaurado para o português.

Figura 4 - Representação da correspondência dos tempos verbais nas traduções francesa e portuguesa, a partir da língua Tupinambá.

Figura 5 - Representação do distanciamento temporal entre as publicações do Colóquio

Figura 6 - Diagrama da $1^{\text {a }}$ operação plurilíngue realizada por Aryon Rodrigues

Figura 7 - Diagrama da $2^{\mathrm{a}}$ operação plurilíngue realizada por Aryon Rodrigues

Figura 8 - Representação dos tempos verbais empregados na tradução literal do

Figura 9 - Representação das correspondências entre os tempos verbais que formam a compõem a $2^{\mathrm{a}}$ operação plurilíngue de Aryon Rodrigues.

Figura 10 - Diagrama da $3^{\mathrm{a}}$ operação plurilíngue realizada por Aryon Rodrigues

Figura 11 - Representação dos enunciados que compõem a $3^{\text {a }}$ operação plurilíngue Figura 12 - Representação dos tempos verbais da $3^{\text {a }}$ operação plurilíngue realizada por Aryon Rodrigues

Figura 13 - Resultado quantitativo das correspondências entre os tempos verbais das duas traduções de Rodrigues para o português atual.

Figura 14 - Diagrama da $4^{\mathrm{a}}$ operação plurilíngue realizada por Aryon Rodrigues

\section{LISTA DE TABELAS}

Tabela 1 - Exemplos de aspectos verbais no Colóquio

Tabela 2 - Correspondência dos tempos verbais utilizados na tradução francesa do Colóquio (1580) e por Aryon Rodrigues (2009).

Tabela 3 - Exemplos de diálogos que não possuem locutores

Tabela 4- Levantamento dos traços fundamentais das traduções visando a Crítica $\quad 70$

Tabela 5 - Razões para retraduzirmos (Gambier, 2012) 72

Tabela 6 - Levantamento de dados sobre os diálogos do Colóquio 110

Tabela 7 - Levantamento dos tempos verbais empregados nas três línguas analisadas no Colóquio 
INTRODUÇÃO 


\title{
PROBLEMÁTICA
}

História de uma viagem feita à terra do Brasil é um clássico da literatura de viagem francesa, originalmente publicado em 1578, pelo missionário calvinista Jean de Léry (15361613). É uma obra de grande valor documental tanto por seu aspecto histórico, quanto linguístico, pois foi construído a partir de observações sobre a língua e cultura dos índios Tupinambá do Rio de Janeiro; Jean de Léry é considerado por Claude Lévi-Strauss e Frank Lestringant o autor mais imparcial, dentre todos os cronistas de literatura de viagem do século XVI, no que se refere à descrição da cultura dos índios Tupinambá. Outros autores franceses que também escreveram crônicas de suas viagens ao Brasil são Claude d'Abeville, Yves d'Évreux, e André Thévet, que apresentam relatos que tratam principalmente sobre a questão da conversão do selvagem dos índios Tupinambá à fé católica e seus costumes "selvagens". Estas narrativas têm em comum a exaltação da superioridade do homem civilizado frente ao índio "sem fé e sem lei" ${ }^{1}$. Estas reações estão diretamente relacionadas à visão de mundo destes autores oriunda do renascimento.

Numa entrevista concedida à Andrea Daher, Lestringant ${ }^{2}$ discute os fundamentos do renascimento:

\begin{abstract}
O Renascimento calcava-se numa concepção estreita do homem. Tinha por ideal os grandes homens da Antiguidade, como Sócrates, os filósofos, os oradores, e também os guerreiros, como Leônidas. Portanto, era uma imagem do homem fixada pelos Antigos e transmitida aos séculos posteriores por Platão, por Cícero, pelas tragédias gregas, ou ainda pelos historiadores, Heródoto, Tucídides, Tito Lívio e outros. Por isso, essa visão estreita e, numa certa medida, etnocêntrica da humanidade, que nasceu na Grécia e, em seguida, imigrou para Roma, mas que não considera a diversidade de raças, a diversidade formidável de culturas, ou seja, que considera certo tipo de humanidade. (LESTRINGANT, 2010:167)
\end{abstract}

Esta colocação de Lestringant explicita como este pensamento oriundo do movimento renascentista moldou as interações sociais do homem no século XVI - esta visão estreita, baseada nos "grandes homens da Antiguidade", limitou o homem e deixou-o isolado na sua visão de mundo etnocêntrica, desconsiderando a humanidade na diversidade de povos e culturas existentes, colocando-se superior a eles. O humanismo surgiu como um movimento que trouxe uma perspectiva renovada sobre o renascimento, que valorizava o ser humano e as suas capacidades. A partir deste movimento, os humanistas introduziram a racionalização, o que permitiu o desenvolvimento do conhecimento científico. Esta nova perspectiva sobre o

\footnotetext{
${ }^{1}$ Cf.: Sans foi, ni loi

${ }^{2}$ LESTRINGANT, Frank. Entrevista com Frank Lestringant. Rio de Janeiro: Revista Topoi, v. 11, n. 20, jan.jun. 2010, p. 159-171. Entrevista concedida à Andrea Daher.
} 
homem renascentista favoreceu também o desenvolvimento da Reforma protestante ${ }^{3}$. O conceito antropológico de alteridade foi desenvolvido a partir das premissas do humanismo, no qual a existência de um indivíduo passa a ser condicionada ao reconhecimento da existência do Outro, a partir da visão do Outro ${ }^{4}$. Esta nova visão é sensível à experiência pelo contato no âmbito da expansão europeia com o período das Grandes Navegações, a partir do século XV. É inevitável ressaltar que o conceito de alteridade moldou o relato de Jean de Léry, pois, enquanto missionário calvinista, ele passa a admitir a existência do Outro em todas suas particularidades, pois, sua experiência não estava mais limitada ao eurocentrismo, passou por um processo de renovação através da experiência pelo contato, ou seja, a visão de certo tipo de humanidade passou a não ser mais concebida como única, mas como uma possibilidade diferente de existir. A partir desta perspectiva, entendemos que o relato de Léry pode ser redescoberto como um questionamento do olhar pré-concebido sobre o Outro e sobre si, a elaboração de um conhecimento mais objetivo ou pelo menos renovado do povo que o acolhe neste Novo Mundo 5 .

Lestringant compara a perspectiva de alteridade de Léry à de André Thévet, outro autor francês contemporâneo de Léry, diante do contexto de descrição do índio Tupinambá presente em ambos os relatos de viagem:

\begin{abstract}
Léry - por mais moderno que seja, inegavelmente - não procede da mesma maneira. Frente ao outro, há também a sua própria presença, numa espécie de "cara a cara" entre o observador e o observado. Léry, com grande inteligência e um senso de reflexibilidade muito agudo, coloca em cena esse "cara a cara" que ora é um olhar cúmplice e amigável, ora uma relação de hostilidade. E por vezes, ambos: entre a hostilidade e a amizade sincera. Por isso, Léry é moderno. (LESTRINGANT, 2010:163)
\end{abstract}

Este reconhecimento do Outro é mais evidente no Colóquio entre as gentes do país, texto que constitui o capítulo XX do relato de viagem de Jean de Léry. O Colóquio apresenta informações de cunho etnográfico sobre a cultura e língua dos índios Tupinambá, tornando-se um testemunho dos primórdios da colonização do Brasil. Essas informações são apresentadas no formato intercalado de 212 diálogos entre um índio Tupinambá e um viajante francês, onde Léry descreve os elementos pertencentes ao mundo natural e objetos culturais particulares da realidade dos índios Tupinambás. Este entendimento sobre as observações de cunho científico contribui para a solidificação de uma escrita mais imparcial, mas isto certamente não exclui o

\footnotetext{
${ }^{3}$ DELUMEAU, Jean;WANEGFFELEN,Thierry. Naissance et affirmation de la Réforme, PUF, Paris, 1997

${ }^{4}$ Cf. BRISSET, Annie. Perspectivas culturais sobre a tradução, 2010.

${ }^{5}$ Cf. GOHARD-RADENKOVIC, Aline. L'altérité » dans les récits de voyage, 1999.
} 
fato de que este texto também apresenta uma marca etnocêntrica em sua tradução da língua Tupinambá para a língua francesa falada no século XVI. O estudo de caso desta tradução etnocêntrica constitui a primeira problemática de nossa pesquisa, porque ela nos direciona à discussão da descoberta da visão sobre o Outro, isto é, como a alteridade de um indígena brasileiro é retratada no discurso de um missionário europeu do século XVI.

Para Berman (2007:28), a tradução etnocêntrica é uma das formas mais tradicionais e dominantes na tradução literária, ela é aquela "que traz tudo à sua própria cultura, às suas normas e valores, e considera o que se encontra fora dela - o Estrangeiro - como negativo ou, no máximo, bom para ser anexado, adaptado, para aumentar a riqueza desta cultura", de modo que "a captação do sentido sempre afirma a primazia de uma língua" (BERMAN, 2007:33). No caso da tradução em língua francesa do Colóquio, o privilégio foi determinado através da recepção do público leitor, o europeu do século XVI. Devemos esclarecer que a tradução francesa do Colóquio, que por vezes aclimata o discurso do índio Tupinambá, ao ponto de naturalizar sua singularidade e estrangeiridade, foi uma estratégia para que conseguisse comunicar o que sua obra pretendia. Nos Estudos da Tradução esta estratégia é utilizada para lidar com a Realia. A Realia é "usada para se referir a conceitos que são encontrados em uma determinada cultura fonte, mas não na cultura alvo" (LEPPIHALME, 2011:126). Isto ocorre porque cada cultura constrói uma realidade de modo diferente. Esta realidade transparece nos elementos lexicais, que se referem ao conteúdo extralinguístico ${ }^{6}$. Ao lidar com a Realia, estabelecemos diferentes estratégias de tradução, o maior questionamento neste processo é a correspondência no âmbito da tradução cultural; perguntado sobre este assunto, Aryon Rodrigues (ADR) abordou este impasse do processo tradutório em uma entrevista ${ }^{7}$ concedida à Prof. ${ }^{a}$ Dr. ${ }^{a}$ Ana Helena Rossi (AHR), para a revista Traduzires:

\footnotetext{
AHR: Como o Sr. resolve conceitos e situações que não existem em outra língua em termos culturais, de representação da realidade?

ADR: Se ele [tradutor] domina as duas línguas, quando há desencontro de concepções básicas, o que ele faz é simplesmente descrever na língua que ele está usando, para a qual ele está traduzindo, uma tradução mais ou menos literal do que os outros dizem, e aí ele tem que interpretar um pouco, dizer como eles estão entendendo aquilo que é diferente do que ele mesmo aprendeu. Ele tem que estar com o pé nos dois lados, do lado da língua do outro, e da língua dele para a qual ele está traduzindo. (RODRIGUES, 2012:130)
}

\footnotetext{
${ }^{6}$ Cf. Leppihalme, 2001:139.

${ }^{7}$ Cf. RODRIGUES, A. D. 2012.
} 
Esta estratégia de tradução literal, postulada por Aryon Rodrigues, é uma das operações que identificamos em seu projeto etnolinguístico de retradução da língua Tupinambá original (1580). Rodrigues compreende os distanciamentos entre a cultura francesa e a indígena, por isso recorreu à tradução literal para se traduzir "conceitos e situações que não existem em outra língua". Nesta pesquisa, compreendemos que a estratégia de Rodrigues se insere nos estudos estruturalistas de Saussure (2006:41) na medida em que "língua é forma e não substância". A tradução literal neste sentido é o método para se conhecer esta forma da língua.

Estudar os aspectos gramaticais de uma língua se insere na pesquisa da forma da língua. Sobre este ponto, realizamos um levantamento de dados sobre a tradução da língua Tupinambá original para o francês, reproduzida por Jean de Léry no Colóquio: 25\% dos tempos verbais não são compatíveis com a tradução do Tupinambá original, a partir de sua restauração. Este dado surge a partir do momento em que confrontamos a tradução de Jean de Léry com a retradução de Aryon Rodrigues da língua Tupinambá para o português (2009). O estudo de caso desta retradução torna-se a segunda e principal problemática de nossa pesquisa, porque pretendemos evidenciar o percurso de Aryon Rodrigues, enquanto, primeiramente, um linguista, ao elaborar a restauração da língua Tupinambá original a partir da linguística descritiva e o método da tradução literal, para retomar informações sobre as estruturas linguísticas desta língua que não possui mais falantes. Esta análise de retradução compreende a Crítica das traduções brasileiras do Colóquio, na presença da língua Tupinambá original, o francês do século XVI e a língua portuguesa. Neste sentido, a problemática cingese na relação que Aryon Rodrigues estabelece com a tradução, a partir de um nível linguístico, onde a tradução não se sustenta como uma finalidade, mas um método para a restauração de uma língua, no caso desta pesquisa, especificamente, a língua Tupinambá falada no século XVI. Na perspectiva de Rodrigues (2012:127), a linguística e a tradução se relacionam sob a perspectiva da "capacidade de comunicação através das línguas, e não apenas comunicação, mas organização do pensamento."

Após introduzir as principais problemáticas deste trabalho, passamos aos conceitos que serão utilizados para desenvolver o estudo do projeto etnolinguístico de Aryon Rodrigues. Em relação à primeira problemática, abordaremos os principais aspectos identificados na tradução francesa do Tupinambá original, influenciada em parte pelo humanismo, e em parte pelo etnocentrismo. Esta análise será realizada a partir dos estudos dos valores dos tempos verbais empregados no Colóquio. 
Seguindo esta linha de trabalho, passaremos à análise da retradução da língua Tupinambá original de 1580 por Aryon Rodrigues, que será abordada, primeiramente, sob a luz dos estudos da (re) tradução introduzidos por Walter Benjamin, Antoine Berman e Yves Gambier. Dando continuidade a estes estudos, a partir do desmembramento deste conceito, pretendemos estabelecer uma relação direta entre Crítica e retradução, tendo como base o trabalho de Antoine Berman em Pour une critique des traductions. Neste sentido, pretendemos discutir brevemente a relação de crítica produtiva que Aryon Rodrigues estabelece com as primeiras traduções do Colóquio para o português. Esta fundamentação teórica e metodológica nos servirá de base para analisar as operações plurilíngues de Aryon Rodrigues a fim de estabelecer um conhecimento linguístico e histórico da língua dos índios Tupinambá do Rio de Janeiro no século XVI.

No terceiro capítulo, o projeto etnolinguístico de Aryon Rodrigues será analisado à luz dos estudos da Linguística descritiva, introduzidas por Joaquim Mattoso Câmara Júnior, Ferdinand de Saussure e Louis Hjelmslev, com a finalidade de investigar as operações plurilíngues que compõem o projeto. Assim, sob uma perspectiva que se adeque à formação de pensamento de Rodrigues, enquanto linguista, será possível verificar o tratamento dado ao texto original, a partir da restauração da língua Tupinambá. Não se trata de traduzir por traduzir, trata-se do estabelecimento de um conhecimento científico a partir do estudo linguístico das línguas que o texto contém, concretizado a partir de operações linguísticas que descrevem as estruturas das palavras em determinado momento da história. Uma das principais questões deste trabalho é demonstrar a relação entre a Linguística e a Tradução no que tange a abordagem da investigação da forma de uma língua.

Em suma, a problemática desta pesquisa envolve a investigação da intencionalidade na conversão linguística do discurso oral do índio Tupinambá para a escrita. Neste sentido, trataremos do projeto etnolinguístico de Aryon Rodrigues para resgatar as singularidades e a estrangeiridade inerente ao Colóquio, através do estudo da estrutura da língua Tupinambá original, que tem por característica principal listas com observações sobre a cultura e a língua dos índios Tupinambá, a fauna e a flora brasileiras, expandindo nosso conhecimento sobre o período nos idos do Brasil Colônia. 


\section{OBJETIVOS}

Nesta pesquisa objetivamos estudar o projeto etnolinguístico de Aryon Rodrigues para o Colóquio entre as gentes do país, concretizado através da restauração da língua Tupinambá a partir da grafia adotada pelos jesuítas no século XVII, e de sua retradução do Tupinambá original de 1580 para a língua portuguesa. No que diz respeito à etnolinguística, admitimos o conceito postulado por Jean Dubois et al. em seu Dictionnaire de linguistique et des sciences du langage, no qual ela é definida como o "estudo da língua enquanto expressão de uma cultura, que trata das relações entre a Linguística e a visão do mundo" ${ }^{8}$. A partir deste conceito, entendemos que as línguas operam como agentes difusores de visões de mundo, porque contém dados culturais de um povo. A partir do estudo da língua (forma), passamos a compreender esta dimensão cultural. Para Rodrigues (2012:127), "a língua está adaptada à cultura do povo", portanto, estas relações entre língua e cultura vão orientar as discussões em torno da análise da tradução da língua francesa do século XVI e do projeto etnolinguístico de Aryon Rodrigues.

O interesse em tratar nesta pesquisa as retraduções propostas por Aryon Rodrigues, parte do princípio do estabelecimento do conhecimento científico, que pode ser realizado através do ato tradutório, um ato que, neste Colóquio, de acordo com o projeto de Aryon Rodrigues, inclui colocar seus estudos linguísticos em jogo, estudos que contribuem para a elaboração de informações etnográficas fornecidas através do Colóquio publicado por Jean de. Por isso, discutimos ao longo deste trabalho as operações plurilíngues de Aryon Rodrigues na perspectiva dos estudos sobre retradução, Crítica e Linguística descritiva, fundamentandoos na visão de Aryon Rodrigues sobre a tradução: um método da Linguística na reconstrução de uma língua indígena que não possui mais falantes. A partir destes estudos, analisamos concretamente o resultado destas operações, para descobrirmos qual o nível de contribuição que estas operações trouxeram para a formação de um conhecimento sobre o Colóquio entre as gentes do país.

A partir da abordagem da metodologia da Linguística adotada por Aryon Rodrigues, trabalhamos com a hipótese central de que sua restauração e retradução do Tupinambá original seria, de fato, o retorno à forma desta língua, tal como era falada no século XVI. Isto contribuiria para trazer à luz a alteridade do índio Tupinambá representado nos diálogos do Colóquio do século XVI. Neste sentido, a retradução de Aryon Rodrigues revelaria uma visão

\footnotetext{
${ }^{8}$ Cf. DUBOIS, 1994:186
} 
sobre o indígena, reconstruída a partir de elementos científicos baseados no estudo descritivo da língua Tupinambá, reafirmando um caminho para o conhecimento e enriquecimento linguístico e histórico da nação Tupinambá.

\section{JUSTIFICATIVA}

A edição de 2009 do Colóquio entre as gentes do país, publicada pela Fundação Darcy Ribeiro, foi traduzida por Aryon Rodrigues e se trata da mais recente edição que temos da obra de Jean de Léry em língua portuguesa. O objetivo de estudar o texto do Colóquio é por ser um registro detalhado sobre a língua e a cultura dos índios Tupinambá do século XVI e por trazer informações etnográficas a partir de observações de cunho etnográfico realizadas por Jean de Léry no Novo Mundo. Além das particularidades sobre esta documentação histórica do Brasil presentes no Colóquio, Jean de Léry reproduz a primeira tradução dos diálogos transcritos em língua Tupinambá para a língua francesa do século XVI. Estes diálogos contêm listas de instrumentos de guerra, nomes de comidas, nomes de animais, pronomes pessoais em língua Tupinambá, entre outras informações sobre a tribo e a cultura indígena.

Este Colóquio é o corpus de pesquisa de dois projetos de iniciação científica desenvolvidos sob a orientação da Prof. ${ }^{a}$ Dra. Ana Helena Rossi, entre os anos 2011 e 2014 intitulados respectivamente: Traduções do diário de viagem de Jean de Léry (1578): visões sobre o indígena e Projeto de tradução e construção da visão sobre o indígena: Aryon Dall'Igna Rodrigues, tradutor do diário de viagem de Jean de Léry (1578); no primeiro projeto de iniciação científica, os diálogos do Colóquio foram analisados sob a luz dos estudos dos valores dos modos e tempos verbais da língua francesa do século XVI e do português utilizados na construção dos discurso do viajante francês e do índio Tupinambá; no segundo projeto de iniciação científica, adentramos mais na construção do perfil de Aryon Rodrigues como tradutor do Colóquio e a definição de seu projeto etnolinguístico.

O interesse em dar continuidade a estas pesquisas reside no fato do Colóquio ser um texto denso e interdisciplinar, por dialogar com diversas grandes áreas de conhecimento, como por exemplo, a História, Antropologia, Estudos Literários, Linguística e os Estudos da Tradução. Nesta pesquisa, escolhemos trabalhar com o recorte de análise das retraduções de Aryon Rodrigues, como um método para a restauração linguística, que convergirá no resgate da visão sobre o Outro. 


\title{
CONTEÚDO
}

Nossa pesquisa repousa no projeto de restauração e retradução desenvolvido por Aryon Rodrigues, a partir da descrição da estrutura formal e da tradução da língua Tupinambá do século XVI. Este projeto é pertinente porque restaura um conhecimento sobre os aspectos culturais e linguísticos dos índios Tupinambá, que foram adaptados na tradução francesa da língua Tupinambá, reproduzida na edição de 1580 do Colóquio.

Entretanto, é preciso pontuar que estas adaptações não ocorrem apenas na escrita do original, ele é intrínseco às primeiras traduções do Colóquio para o português, publicadas por Batista Caetano (1876), Tristão Araripe (1889), Monteiro Lobato (1926), e Plínio Ayrosa (1941). Em uma entrevista concedida à Prof. ${ }^{a}$ Dr. ${ }^{a}$ Eni Puccinelli Orlandi em 2013, Aryon Rodrigues relata seu primeiro contato com a tradução de História de uma viagem feita à terra do Brasil, ao lê-la aos catorze anos de idade, e sua relação com a língua Tupi transcrita por Jean de Léry:

\begin{abstract}
Aryon: Tentei aprender Tupi pelo Jean de Léry, na tradução do Monteiro Lobato, tudo escrito estropiado. Estropiado já na edição francesa original. Porque o Paul Gaffarel não conseguiu ler direito certas coisas do manuscrito do de Léry, trocando "u" por "n", e coisas assim. E depois, a versão brasileira se estropiou ainda mais. Mas eu tomei tudo como coisa certa e estava tentando aprender por ali. (RODRIGUES, 2013:24)
\end{abstract}

Este posicionamento crítico de Aryon Rodrigues pondera que existem complicações da própria reprodução do original que se multiplicam nas edições e traduções posteriores, porque nestas publicações o original não é contemplado; não há um retorno ao original, apenas a replicação de erros por falta de uma leitura crítica. Entendemos que esta análise não cabe a todos os autores e tradutores, por isso devem ser analisadas conforme seus projetos de execução. Neste sentido, Rodrigues analisa as traduções do Colóquio que apresentaram uma proposta semelhante a sua. Neste aspecto, Rodrigues pode desenvolver uma crítica produtiva sobre estas publicações e pluralizar o conhecimento científico, não reduzindo o merecimento dos tradutores anteriores a ele, que realizaram seus trabalhos em pontos históricos e científicos distintos dos seus. A tradução de Plínio Ayrosa é a mais comentada por Aryon Rodrigues em seu prefácio Contribuições linguísticas de Jean de Léry (2009); as Críticas são movidas pelo fato da tradução de Ayrosa, anterior a de Rodrigues, ter sofrido duras críticas após sua publicação, porque Ayrosa restaurou a língua Tupinambá concebendo-a como igual à língua Guarani. Em outro trecho da entrevista concedida à Eni Puccinelli Orlandi, Rodrigues 
explica brevemente o porquê desta não ser uma tradução adequada do ponto de vista da Linguística:

\begin{abstract}
Aryon: O primeiro grande crítico dele foi o padre Antonio Lemos Barbosa, do Rio de Janeiro [...] Ele criticou, sobretudo, uma certa edição do Jean de Léry, traduzida pelo Sérgio Milliet, na qual o Ayrosa foi encarregado de fazer todo o tratamento dos textos em Tupinambá. Foi um desastre. Ele pôs na cabeça, primeiramente, de substituir a escrita original por uma de criação dele. Aí já tirou todo o caráter documental do livro, do ponto de vista do linguista. Por outro lado, quis corrigir as traduções do francês, quis corrigir tudo e ele criou coisas erradas da parte dele. Então ficou muito ruim, infelizmente. É uma edição que não se aproveita para a Linguística. (RODRIGUES, 2013:25)
\end{abstract}

O estudo aprofundado das Críticas das traduções do "Colóquio entre as gentes do país", constitui um conteúdo de extrema relevância para a análise do projeto de retradução de Aryon Rodrigues sob a luz dos estudos da Linguística, porque no fornece um material comparativo, com Críticas que vão além do estudo comparativo formal, porque são concebidas no âmbito da cientificidade da língua Tupinambá. Estas críticas auxiliam na construção do objeto de nossa pesquisa porque fundamentam nossos argumentos sobre as contribuições linguísticas de Aryon Rodrigues para o texto de Jean de Léry. Por isto, o estudo da Crítica relacionado ao conceito de retradução é um objeto abordado nesta pesquisa.

No primeiro capítulo apresentamos uma biografia de Jean de Léry, destacando sua formação ideológica e religiosa, que nos ajuda a elaborar o seu horizonte autoral e determinar o perfil do público-alvo de sua obra História de uma viagem feita à terra do Brasil. A partir desta introdução ao perfil de Léry, desenvolvemos a hipótese de que o Colóquio publicado em sua obra, não é de autoria completa de Léry, mas de vários franceses e truchements que utilizavam o Colóquio como um guia de conversação voltado para missionários e marinheiros que interagiam com os índios Tupinambá a fim de estabelecer uma relação amistosa que favoreceria o comércio de matérias-primas brasileiras e o recrutamento de força de trabalho indígena na tentativa de constituir a baía da Guanabara como a nova colônia francesa, a França Antártica. A visão de mundo de Léry é influenciada pela sua recusa da intolerância religiosa, o que consequentemente reflete no projeto de escritura do relato de viagem, porque afeta o modo como percebe o índio Tupinambá. Neste sentido, objetivamos analisar de forma especial o estado da língua Tupinambá no século XVI, até a elaboração do Diretório dos Índios em 1755, por Marquês de Pombal, que constitui um marco para a comunicação das Língua Geral no território brasileiro, tendo em vista que este Diretório estabelecia a proibição do seu uso, e instaurava a obrigatoriedade do ensino da língua portuguesa. A partir desta introdução ao universo de Jean de Léry, apresentamos a estrutura do Colóquio e as etapas 
metodológicas que utilizamos para realizar o tratamento dos dados dos diálogos reproduzidos por Léry.

No segundo capítulo desta pesquisa, apresentamos a fundamentação teórica e metodológica aplicadas nesta pesquisa. As linhas teóricas que norteiam este trabalho incluem estudos sobre a retradução na perspectiva de Walter Benjamin, dentro do conceito do continuum de conversões; Antoine Berman, nas retraduções como grandes traduções; e Yves Gambier, complementando o discurso de Berman com a teoria do détour et retour (1994). Neste sentido, relacionamos os conceitos apresentados ao estudo sobre a Crítica de traduções introduzido por Berman em Pour une Critique des traductions (1995). A partir destes referenciais teóricos, buscamos demonstrar neste capítulo como a retradução assume o papel de um posicionamento crítico, mas, sendo este um posicionamento positivo e produtivo.

No terceiro capítulo, tratamos de Aryon Rodrigues e de sua experiência enquanto linguista e tradutor responsável pela restauração da língua Tupinambá original e sua retradução para o Colóquio de Jean de Léry (2009). Neste espaço traçamos sua trajetória acadêmica e discutimos o seu posicionamento em relação ao seu projeto etnolinguístico de restauração da língua Tupinambá original. Este posicionamento será evidenciado através da desconstrução do projeto etnolinguístico de Aryon Rodrigues, analisado em um contexto de quatro operações plurilíngues realizadas por ele. Estas operações são elaboradas a partir da extensa pesquisa dedicada às línguas indígenas por Aryon Rodrigues, especialmente, a propósito da Linguística descritiva. Lia Wyler (2012:248) reafirma em seu texto Línguas, Poetas e Bacharéis: uma crônica da tradução no Brasil que "Toda reescritura, seja qual for a intenção, reflete uma ideologia". No caso das retraduções de Aryon Rodrigues, elas surgem para demonstrar que elas podem pluralizar e acrescentar informações sobre os idos da colonização brasileira a este texto de valor documental histórico e linguístico.

A hipótese com a qual trabalhamos neste capítulo é de que o projeto etnolinguístico de Aryon Rodrigues contribui para um enriquecimento cultural, linguístico e histórico dos índios Tupinambá. Isto ocorre a partir da restauração do discurso do índio Tupinambá através do método da linguística descritiva e da tradução literal inseridos nas operações plurilíngues. Assim, podemos reler o Colóquio com um olhar mais objetivo sobre o enunciador dos diálogos, que passa a ser o índio, não o viajante europeu do século XVI, que interpretou o discurso do índio de acordo com a sua visão de mundo. Ao final deste trabalho, apresentamos algumas considerações finais sobre as hipóteses trabalhadas nesta pesquisa. 


\section{CAPÍTULO 1}

\section{JEAN DE LÉRY: O HUGUENOTE E A ESCRITA DA HISTÓRIA}

Que nada permaneça estranho para o homem e que tudo se torne servidor dele.

Alphonse Dupront 


\subsection{JEAN DE LÉRY: MISSIONÁRIO CALVINISTA NO BRASIL}

Neste primeiro capítulo abordaremos os principais momentos da trajetória de vida de Jean de Léry e apresentaremos uma leitura analítica do capítulo XX de História de uma viagem feita à terra do Brasil intitulado Colóquio entre as gentes do país, com uma abordagem do projeto de escritura do autor e de sua autotradução. Esta distinção na abordagem do Colóquio se torna necessária, pois consideramos que "a intenção do escritor é ingênua, primeira, intuitiva; a do tradutor, derivada, última, ideativa" (BENJAMIN, 2008:75). O objetivo de analisarmos o texto fonte que deu origem ao projeto etnolinguístico de restauração e retradução de Aryon Rodrigues consiste na tarefa de localizar as zonas significativas através dos traços da escrita do autor (BERMAN, 1995:67); acreditamos que a forma do original, a qual devemos retornar quando traduzimos, reside nestas zonas significativas. A seguir, veremos como se deu a formação social de Jean de Léry e a elaboração de sua obra.

Jean de Léry nasceu em La Margelle na região da Borgonha em 1534. Trabalhava como sapateiro e estudava teologia. Léry embarcou para o Brasil com outros artesãos a fim de participar da tentativa de colonização francesa no Rio de Janeiro, a França Antártica, integrando também a expedição dos reformistas para o Novo Mundo motivado "tanto em virtude do grande desejo que Deus lhe dera, já então, de pôr-se a serviço de Sua glória, quanto por se sentir curioso desse mundo novo" ${ }^{9}$. Na recém-criada colônia francesa de Forte-Coligny havia a promessa de liberdade religiosa para os protestantes, fator que motivou a ida de Jean de Léry ao Brasil. Sob o comando desta colônia estava Nicolas Durand de Villegagnon, cavaleiro da Ordem de Malta e oficial de marinha.

Após oito meses vivendo na França Antártica, os reformistas passaram a ser perseguidos por Villegagnon, que ordenou suas expulsões da colônia francesa - e, os que resistiram foram massacrados. Jean de Léry e outros calvinistas viveram refugiados por dois meses em um aldeamento dos índios Tupinambás. Durante este tempo, Léry fez diversas observações sobre a cultura, religião, língua e costumes destes índios relatando as curiosidades sobre o Novo Mundo. Ele também denunciou as perseguições religiosas vividas pelos calvinistas no Forte-Coligny, fazendo duras críticas a Villegagnon. Passados os dois

\footnotetext{
${ }^{9}$ Cf. nota biográfica por Paul Gaffarel, p. 10 em LÉRY, Jean de. Viagem à Terra do Brasil: Tradução integral e notas de Sérgio Milliet segundo a edição de Paul Gaffarel com o colóquio na língua brasílica e notas tupinológicas de Plínio Ayrosa. 2a . ed. Rio de Janeiro: Biblioteca do Exército,1961. Coleção General Benício, v. $5.220 \mathrm{p}$.
} 
meses, Jean de Léry e outros missionários conseguiram regressar à França. Léry permaneceu no Brasil durante o período de março de 1557 a janeiro de 1558 - seu diário de viagem intitulado: História de uma viagem feita à terra do Brasil, também chamada América foi publicado vinte anos após seu regresso a Europa em $1578^{10}$. Esta escrita de Léry é a que caracterizamos como primeira e intuitiva, é a que caracteriza o objeto geral da obra.

Jean de Léry, enquanto missionário calvinista e cronista, publicou seu diário de viagem com finalidades prático-religiosas: determinado a desmentir o que ele considerava como calúnias e difamações ditas por André Thévet em relação às Américas e aos ministros calvinistas que participaram da expedição ao Brasil, no seu livro intitulado: Les Singularités [As Singularidades], publicado em 1557. Léry decidiu relatar o que havia presenciado, com o objetivo de informar o público leitor sobre a realidade das expedições e sobre a terra brasileira. De acordo com Léry (1961:39), "minha intenção e meu objetivo serão apenas contar o que pratiquei, vi, ouvi e observei, quer no mar, na ida e na volta, quer entre os selvagens americanos com os quais convivi durante mais ou menos um ano". Esta é a escrita do tradutor que nos referimos inicialmente, uma escrita última e ideativa, porque ela caracteriza um projeto específico para a obra, o projeto de tradução de Jean de Léry.

Ele escreveu para um público que embora não tivesse uma preocupação científica, como o interesse em suas notas sobre a gramática da língua dos índios Tupinambás, "manifestava um grande interesse em conhecer o exótico" (ORLANDI, 2008:94) e o incomum oriundos do Novo Mundo, porque se tratava de uma realidade desconhecida para a sociedade europeia do século XVI. O livro obteve um grande sucesso na Europa ao ponto de eclipsar o livro de André Thévet, Les Singularités.

\subsection{LÍNGUAS E TRUCHEMENTS: OS INTÉRPRETES NO BRASIL COLÔNIA}

Durante o período de colonização no Brasil (1500-1822), as línguas indígenas predominavam em todo o território brasileiro. Aryon Rodrigues ${ }^{11}$ estima que no ano de 1500 fossem faladas cerca de 1270 línguas indígenas. Com esta grande variedade de línguas os colonos europeus que habitavam a costa brasileira exerciam o ofício de intérpretes. Eles deram início às atividades de tradução oral antes mesmo da chegada dos missionários.

\footnotetext{
${ }^{10}$ LÉRY, Jean de. Op. cit., p. 10.

${ }^{11}$ Cf. RODRIGUES, A.D. 1986.
} 
Jean de Léry relata em vários trechos de sua obra, História de uma viagem feita à terra do Brasil, que estava acompanhado por um intérprete quando visitava os aldeamentos indígenas: "Visitei esses selvagens pela primeira vez três semanas depois de nossa chegada à ilha de Villegagnon e fui em companhia de um intérprete a três ou quatro aldeias do Continente" (LÉRY, 2007:234). Ele chegou a relatar também que, por vezes, o próprio intérprete que vivia entre os índios do aldeamento, recepcionava os franceses e intermediava as negociações e conversas com os índios Tupinambá. Segundo Léry (2007:235), os franceses chegaram a nomear um aldeamento de acordo com o nome do intérprete que ali vivia: "Nesse mesmo dia eu e o intérprete tocamos para diante e fomos dormir na segunda aldeia chamada Eyramiri e que os nossos denominam Goset por causa do trugimão aí residente". Estes intérpretes ficaram conhecidos com os truchements ${ }^{12}$. A palavra truchement deriva do Árabe tardjeman. Esta palavra entra na língua francesa no século XII como drugement para designar os intérpretes árabes da época das Cruzadas (ABBEELLE, 2014:190) ${ }^{13}$. No entanto, é importante ressaltarmos que,

[...] os truchements desta época não são intérpretes como no sentido atual da palavra. Eles eram, certamente, jovens normandos abandonados na terra dos Ameríndios, que eram acolhidos por estes. Ele se casavam, tinham filhos com as índias americanas. Em suma, eles se integravam tornando-se membros da tribo, até o dia em que a chegada de seus compatriotas os colocavam à frente do reencontro com estrangeiros que não lhes eram exatamente 'estranhos'. (ABBEELE, 2014:190, tradução nossa) ${ }^{14}$

Jean de Léry (2007:59) corrobora esta informação sobre o abandono dos jovens normandos, ao relatar em sua obra que "no terceiro barco, que se chamava Rosée, por causa do nome de quem o comandava, iam quase noventa pessoas, inclusive seis meninos, que levávamos para que aprendessem a língua dos selvagens". O Embarque de Léry e destas crianças ocorreu em Honfleur, na Normandia. De fato, Léry menciona diversas vezes em seu relato que estes truchements eram, em sua maioria, normandos, e poucos bretões. Em uma

\footnotetext{
${ }^{12}$ Cf. ABBEELLE, 2014:190 - O truchement pode ser assimilado à outras palavras francesas (tais como tricher, trucher, truffer e assim por diante). No original: Le mot "truchement " dérive de l'Arabe, tardjeman. Il entre dans la langue française au XIIe siècle comme "drugement " pour désigner les interprètes arabes de l'époque des Croisades. Le truchement se lie aussi à d'autres mots français (tels tricher, trucher, truffer et ainsi de suite). ${ }^{13}$ Cf. LÉRY, 2007:[...] ]explicarei que os nossos capitães, mestres, soldados marinheiros, em sua maioria normandos, gente tão valente belicosa no mar como a que mais o seja, estavam todos resolvidos a atacar e combater a armada do Rei de Portugal, vangloriando-se de alcançar vitória".

${ }^{14}$ No original em francês: "les «truchements » de l'époque ne sont pas des interprètes au sens courant. C'étaient apparemment de jeunes normands abandonnés chez les Amérindiens, qui se faisaient adopter par ceux-ci. Ils se mariaient, avaient des enfants avec des indigènes américains. Bref, ils s'y assimilaient en devenant membres de la tribu, jusqu'au jour où l'arrivée de leurs compatriotes les mettaient au premier plan de la rencontre avec des étrangers qui ne leur étaient pas tout à fait "étrangers »."
} 
carta de Richier à Calvino ${ }^{15}$, ele menciona estes meninos e a necessidade do aprendizado da língua indígena: "Mas o grande obstáculo é a diversidade de idiomas. Acrescente-se que não temos intérpretes fiéis a Deus. O mérito de nossa obra consiste para nós em refrear o passo e esperar pacientemente que os adolescentes aprendam a língua dos índios. E já alguns vivem entre eles."

Tomamos conhecimento de duas hipóteses sobre a origem normanda dos truchements: a primeira hipótese refere-se ao início do século XVI, quando Ruão (Rouen) era a segunda cidade mais populosa da França, depois de Paris. "A concentração demográfica encorajaria o possível êxodo de jovens para os lugares em que a França possuía interesses comerciais (como o Brasil, desde a viagem de Gonneville em 1503)". A segunda hipótese é que a situação geográfica da Normandia (região costeira) favorecia as ambições coloniais da França, incentivadas pelo rei Francisco I. "Daí, a quantidade imensa de normandos nas tripulações dos navios franceses e nas comunidades que a França tentava firmar no Canadá, Flórida, Brasil e eventualmente, nas Antilhas" (ABBEELE, 2014:191).

No início do século XVI, muitos navios franceses que vinham dos portos da Normandia (Rouen, Dieppe, Fécamp e Honfleur), aportavam no Brasil para traficar paubrasil, animais e plantas, que eram um negócio muito lucrativo na Europa. O aprendizado das línguas ocorreu através da convivência com os índios e foi motivado pela necessidade dos europeus em exercer um controle sobre eles - para fins comerciais e exploratórios (BARROS, 1994:4). Neste sentido, os marinheiros normandos aprendiam alguns vocábulos da língua Tupinambá, para realizarem negócios com os índios através do escambo. Desta forma, os marinheiros estabeleceram uma relação amistosa com os índios e conseguiram que trabalhassem para os franceses em troca de facas, anzóis, etc.. A partir daí, adquiriram um conhecimento mais profundo sobre a língua. Estes também ficaram conhecidos como os truchements, porque serviam de intérpretes entres os comerciantes franceses e os índios.

De acordo com Freire (2003:97), "em todas as expedições, os europeus entraram em contato com os índios, através de gestos e sinais ou utilizando intérpretes". Os normandos realizavam anotações sobre a língua, gestos e expressões, e repassavam estas anotações a outros marinheiros, para que conseguissem se comunicar e realizar o comércio. Alguns se aventuraram e passaram a viver entre os índios que habitavam a costa do Brasil. Um raro documento dessa época é o Langaige du Bresil, que contém uma lista de 85 termos ou locuções tupis, com uma tradução em francês.

\footnotetext{
${ }^{15}$ Cf. LÉRY, 2007:70. Carta de Richier á Calvino, Amsterdã, 1667:121
} 
Le langaige $d u$ Bresil [...] foi compilado por Jehan Lamy aproximadamente em 1540, época de intensa atividade francesa voltada para o Brasil que conduzirá ao evento da França Antártica em 1555. Este guia de conversação que enriqueceu consideravelmente a pequena lista inserida no diário de Pigafetta, é atualmente o mais antigo testemunho linguístico do Tupi. Ele pode ser considerado como uma espécie de pidgin. [...] Esta lista é por si só o embrião de um relato de viagem, uma espécie de roteiro relatando situações. (SANTOS, 2000:36, tradução nossa) ${ }^{16}$

Jehan Lamy foi um marinheiro (capitão), que nasceu, muito provavelmente, em Ruão (Rouen) (DALBY; HAIR, 1967:66). Segundo Papavero (2014:39), este documento é uma "evidência da frequência das expedições normandas nesta região". Portanto, existe a hipótese deste documento ter sido o início da escrita de um colóquio, inclusive, do que conhecemos através da obra de Jean de Léry, o Colóquio entre as gentes do país. Esta hipótese surgiu a partir da observação de Dalby e Hair (1967) dos diálogos 139 e 140 do Colóquio publicado por Léry. Vejamos o diálogo abaixo:

\section{Diálogo 139 (T)}

(Ia-eh-marape deretani-rere) - Ie t'accorde cela. Comment à nom ton pays \& ta demeure. (De acordo, como é o nome de sua terra.)

Diálogo 140 (F)

(Rouen) - vne ville ainfi nommee. (É uma cidade chamada assim.)

Segundo Dalby e Hair (1967:66), "sabemos que Léry não era normando, mas originário da Borgonha. Rouen era a cidade de origem de muitos truchements e marinheiros das expedições regulares ao Brasil para o tráfico de pau-brasil". Na hipótese de Dalby e Hair, Léry reutilizou um documento que já existia, sem se preocupar em adaptá-lo à sua nacionalidade, enquanto um francês, exilado em Genebra. No entanto, se preocupou em deixar sua identificação logo no início do Colóquio:

Diálogo 4 (T): (Mara-pé déréré?) Comment te nommes tu? Como você se chama? Diálogo 5 (F): (Lery-oussou.) Une grosse huitre. Uma grande ostra.

Dalby e Hair supõem que Léry transcreveu o nome dele em língua Tupinambá para afirmar sua autoria do Colóquio. Mas seu descuido, no diálogo 140, reforçou a hipótese de

\footnotetext{
${ }^{16}$ No original em francês: "Le langaige du Brésil comporte des termes ou locutions tupi-guarani suivies de leur traduction en français. Il fut compilé par un certain Jehan Lamy vers 1540, époque d'intensive activité française vers le Brésil qui mènera à l'épisode de la France Antarctique en 1555. Ce guide de conversation, qui grossit considérablement la maigre liste insérée dans le journal de Pigafetta, est actuellement le plus ancien témoignage linguistique du tupi. Il peut être considéré comme un sorte de pidgin. [...] Cette liste est à elle seule l'embryon d'un récit de voyage, une sorte d'itinéraire inventoriant des situations.
} 
que este Colóquio poderia muito bem ter sido copiado de um trabalho feito por um truchement normando, de Ruão.

O Colóquio é um texto que gera muitas hipóteses no que diz respeito à questão autoral. A investigação da história dos truchements é fundamental para discutirmos a hipótese de que Léry não é o único autor do Colóquio entre as gentes do país, publicado como capítulo XX de sua obra. Na época do lançamento de seu livro, em 1578, André Thévet acusou Jean de Léry de ter plagiado o Colóquio (LESTRINGANT, 2004:89). No entanto, Lestringant (2004:89) afirma que esta acusação de Thévet é apenas uma suspeita infundada, pois outros textos com diálogos franco-tupi foram publicados por "Jacques Cartier, Antoine Pigafetta, ou sob a forma de cadernos manuscritos que circulavam entre os marinheiros. Além disso, Thévet também não tinha provas do roubo, que ele alega que foi cometido por Léry, quando publicou o texto".

Rodrigues menciona em seu prefácio ao Colóquio de Léry, que há uma grande discussão sobre a possibilidade de Léry ter conseguido elaborar o Colóquio e ter aprendido a falar bem a língua dos índios Tupinambá, mesmo tendo ficado apenas dez meses no Brasil, dentre os quais, viveu por apenas dois meses entre os índios Tupinambá. Léry, no entanto, relata que:

Quando cheguei ao país e me pus a aprender-lhes a língua, escrevia sentenças e depois as lia diante deles; e julgavam que era feitiçaria, e diziam uns aos outros: 'Não é maravilhoso que quem ontem não sabia uma palavra de nosso idioma possa hoje ser entendido com um pedaço de papel? (LÉRY, 2007:206)

De acordo com Rodrigues (2009:48), a polêmica sobre a autoria do Colóquio, foi "certamente, mal colocada", porque por um lado, "Léry declarou ter composto o colóquio com a ajuda de um intérprete que tinha vivido de sete ou oito anos junto aos Tupinambá e que, além disso, era bem instruído, mesmo em Grego, o que lhe permitia explicar melhor a língua indígena":

\footnotetext{
Como acompanhei os selvagens até o túmulo, rematarei aqui as minhas observações acerca dos costumes dessa gente. Todavia poderão os leitores encontrar ainda alguma coisa a respeito no colóquio seguinte que compus na América com a ajuda de intérprete muito senhor da língua do país não só por ali ter estado sete ou oito anos mas ainda por tê-la estudado e confrontado com o idioma grego do qual os tupinambás tiraram algumas palavras como poderão observar os que a entendem. (LÉRY, 2009:349)
}

Este posicionamento de Léry, não o descarta como autor do Colóquio, mas o coloca na posição de não ser o único autor do Colóquio - este seria um texto de escrita compartilhada. Um fator que evidencia a presença da colaboração de Léry na escrita do Colóquio é a representação da palavra Tupinambá com a vogal reduplicada: 
Embora não tenha sido nosso propósito comentar nesta edição as expressões da língua Tupinambá usadas por Léry, convém chamar a atenção para o próprio nome Tupinambá. Léry escreve sempre Tououpinamboults, grafia que permite duas possíveis leituras fonéticas: [tuupinambaú] e [tuupinambó]. A representação de [uu] no início da palavra é exclusiva de Léry: todos os demais registros desse nome, tanto dos franceses como os portugueses e o alemão de Hans Staden, têm [u]. (RODRIGUES, 2009:50)

Neste sentido, Aryon Rodrigues (2009:49) reforça a hipótese de Lestringant (2004), Daher (2004), Dalby e Hair (1966), ao considerar que "é bem possível que, como guia de conversação, um mesmo texto básico se multiplicasse em sucessivas cópias manuscritas e que fosse, às vezes, acrescentado com novas contribuições". Este Colóquio reproduziria fragmentos de conversas e discursos reais ou prováveis. Vários franceses poderiam ter compilado "essas conversas, reduzindo-as à escrita, como ajuda à memória e como auxílio a novos aprendizes da língua indígena" (RODRIGUES, 2009:50). Isso explicaria porque Yves d'Évreux $^{17}$, que esteve com os Tupinambá do Maranhão em 1612 e 1613, sessenta anos após a viagem de Léry, publicou um texto com frases muito semelhantes as do Colóquio de Léry,

O texto de Yves d'Évreux traz frases sobre a chegada de um navio francês, que não
se encontram no colóquio de Léry. Por outra parte, o texto de Léry incorpora, o que
aparentemente seria um discurso típico de um hospedeiro Tupinambá saudando a
chegada de seus hóspedes franceses. Yves d'Évreux, por sua vez, apresenta,
separadamente, amostras de conversação em situações sociais típicas dos
Tupinambá entre si (Capítulo 24, 'Regras e meios puramente naturais observados
pelos selvagens, pelos quais levam uma vida muito suave e agradável').
(RODRIGUES, 2009:49)

Reconhecemos em nossa pesquisa que Plínio Ayrosa foi o primeiro tradutor a questionar a autoria de Jean de Léry para o Colóquio: "passa o autor de um assunto para outro com tanta rapidez e desembaraço que chega, quase, a nos dar certeza de que andou copiando, de algum trabalho largo e minucioso, apenas tópicos que julgou de interesse para os leitores da sua viagem" (LÉRY, 2007:272). Porém, Ayrosa admite que é inegável que o autor do Colóquio conhecia perfeitamente a língua, "pois há indícios claros desse conhecimento na composição de certas frases de torneio complexo" (AYROSA, 2007:273). No entanto, Ayrosa recusa a hipótese de que um "simples intérprete" tenha escrito este texto, porque ele não poderia ter tamanha propriedade sobre a língua, mas, supõe que alguém que talvez fosse versado na gramática do latim, provavelmente, tenha preparado grande parte do Colóquio e

\footnotetext{
${ }^{17}$ Yves d'Évreux, Suitte de l'histoire de la mission des Pères Capucins em l'Isle de Maragnan, Paris, 1615, capítulo 50, "Da recepção que fazem os selvagens aos franceses recém-chegados e como convém comportar-se com eles".
} 
que Léry tenha apenas contribuído com algumas palavras de fácil compreensão, como nomes de aves, peixes, plantas, partes do corpo humano, como as citadas nos outros capítulos da sua obra, Viagem à terra do Brasil (AYROSA, 2007:273).

Para Aryon Rodrigues, Léry poderia ter contribuído ou não na escrita do Colóquio, mas a contribuição que Rodrigues garante que Léry forneceu foi a de ter tido a iniciativa de ter publicado o colóquio como complemento de sua História. "ele preservou um documento interessantíssimo, que nos transmite uma bela amostra de fala dialógica coloquial e, ao mesmo tempo, de discurso oratório dos Tupinambás, que em vão procuraríamos na rica literatura produzida pelos missionários portugueses" (RODRIGUES, 2009:49). Rodrigues lembra ainda que Anchieta trouxe várias contribuições também, mas submeteu a língua dos índios Tupinambá "às exigências da métrica e da rima ibéricas. Léry, ao contrário, conservounos, por assim dizer, o Tupinambá tal qual se falava no Rio de Janeiro, no século XVI".

A hipótese que consideramos ser a mais razoável, a partir da discussão dos elementos sobre a autoria do Colóquio, é que este não era um documento com apenas uma autoria, como Jean de Léry deu a entender quando escreveu que ele o tinha elaborado. Entendemos este Colóquio como um documento, que circulava entre os missionários e viajantes desde 1540 e que também consta como a informação mais antiga que se tem sobre um documento semelhante ao Colóquio — , que foi acrescido de observações sobre a língua Tupinambá ao longo dos anos, por vários franceses que viviam entre os índios, e cujo conhecimento da língua era comprovadamente prático, estes autores seriam os truchements.

Villegagnon tentou estabelecer uma colônia francesa na Baía de Guanabara em 1555. Porém, sentiu seu domínio ameaçado ao perceber que os truchements normandos, que habitavam aquele lugar muito antes da sua chegada, possuíam um relacionamento muito íntimo com os índios: se casavam, tinham filhos e até participavam de rituais antropofágicos. Villegagnon temia que estes normandos "selvagens" exercessem uma influência negativa sobre os colonos e marinheiros que estavam sob o seu comando, ao seu ver este comportamento representava uma afronta à religião Católica (ABBEELE, 2014:192). De acordo com Léry,

visando certos normandos, [...] se tinham salvado de um navio que naufragara e haviam ficado entre os selvagens, vivendo amasiados sem temor a Deus, alguns com filhos já de quatro a cinco anos de idade, e a fim de evitar que o mesmo não acontecesse aos de nossa ilha e de nosso fortim, proibiu Villegagnon, depois de ouvir o parecer do conselho, que nenhum cristão se juntasse às mulheres dos selvagens, sob pena de morte, a menos que fossem antes instruídas na religião, e batizadas. (LÉRY, 2007:96) 
Esta sanção causou revolta entre muitos truchements que frequentavam a França Antártica, e entre os subordinados que não queriam mais viver sob o comando autoritário de Villegagnon. Logo surgiu uma conspiração entre estes colonos e os intérpretes normandos para assassinar Villegagnon. Esta conspiração foi descoberta e frustrada por três escoceses, que pertenciam à sua guarda pessoal, e lhe revelaram todo o plano. Jean de Léry, que defendeu a decisão de Villegagnon de colocar limites nas "selvagerias" dos intérpretes normandos, viu sua vida nas mãos destes mesmos intérpretes que escaparam da França Antártica após a tentativa frustrada de assassinato: quando Léry foi expulso da colônia por Villegagon, ele se refugiou entre os índios Tupinambá com a ajuda de um intérprete normando (ABBEELE, 2014:193).

Os truchements se adaptaram tão bem à realidade dos índios brasileiros, que não desejavam regressar mais à sua cultura de origem. Por isso, foram alvos de grandes suspeitas por parte dos representantes do poder colonial. Estas suspeitas mais tarde se confirmaram, quando os truchements lideraram os índios contra as forças colonizadoras, chegando a desmantelar, internamente, a tentativa de colonização francesa no Rio de Janeiro (ABBEELE, 2014: 194). A relação dos truchements com os índios brasileiros que os acolheram, cria, segundo Lestringant, o fenômeno do "endotismo" flagrante, que consiste nos intérpretes que partilhavam da vida indígena, inclusive da antropofagia. Lestringant (1996:18) afirma que este fenômeno exprime "a crença nunca descartada da regressão de indivíduos ou de grupos transplantados em um ambiente hostil e separados de sua história"; ele seria o efeito inverso da civilização, seria o "ensauvagement", o triunfo da selvageria sobre os espíritos civilizados $^{18}$. Léry relata que,

Com pesar sou, porém, forçado a reconhecer aqui que alguns intérpretes normandos, residentes há vários anos no país, tanto se adaptaram aos costumes bestiais dos selvagens que, vivendo como ateus, não só se poluíam em toda espécie de impudicícias com as mulheres selvagens mas ainda excediam os nativos em desumanidade, vangloriando-se mesmo de haver morto e comido prisioneiros. (LÉRY, 2007:201)

Estes truchements que se renderam à vida selvagem dos índios eram fortemente criticados por Léry, porque de acordo com ele, não tinham mais fé em Deus. Para os calvinistas, a conversão de um truchement selvagem, valia tanto ou até mais do que a conversão de um índio.

\footnotetext{
${ }^{18}$ Cf. DAHER, Andrea, 2004:75
} 
Sobre o truchement que auxiliou Léry na escrita do Colóquio, há uma hipótese de que ele seria o mesmo, ou então, no mínimo, um conhecido do truchement que acompanhava Montaigne, que tinha vivido "dez ou doze anos neste outro mundo que foi descoberto, em nosso século, no lugar onde Villegagnon se instalou, que ele designou França Antártica" (NAKAM, G. 2000:22). De acordo com Abbeele (2014:195), "a história destes intérpretes normandos na época das descobertas ainda é muito obscura pelo fato de ser pouco documentada". Se tivéssemos acesso a documentações sobre os truchements, conseguiríamos resultados mais concretos sobre a escrita da língua dos índios Tupinambá do século XVI.

Após o fracasso da colonização francesa, os colonos portugueses ganharam força no território brasileiro. No momento da colonização portuguesa, "os intérpretes tiveram papel decisivo, sobretudo nos primeiros momentos da conquista, no século XVI e início do século XVII, [...] contribuindo decisivamente para o recrutamento da força de trabalho indígena, através dos descimentos e dos resgates" (FREIRE, 2003:99). Barros discorre sobre a formação desses intérpretes e como se dava a recompensa deste trabalho:

No litoral brasileiro, por exemplo, entre as primeiras medidas tomadas para permitir
a interação de índios x portugueses destacam-se aquelas que manifestavam
preocupação em formar 'línguas' ou intérpretes. Alguns colégios jesuítas
funcionaram como centros de especialização de tradutores do discurso religioso em
Língua Brasílica, capacitando, entre outros, os irmãos da Companhia de Jesus que,
não podendo administrar os sacramentos, ajudavam os padres nesta tarefa. A
correspondência dos jesuítas registra também o uso de mamelucos - filhos de índias
com portugueses - operando como mediadores dos missionários na relação com os
índios. Quando o trabalho de "língua" era feito por um colono, a retribuição era o
soldo; quando era realizado por um índio, o pagamento era feito em bens, como
vinho e ferramenta, ou com alguns privilégios, como o cargo de capitão da aldeia.
(BARROS, 1994:4)

Este fato remonta diretamente aos primórdios da história da tradução durante o período de colonização das terras brasileiras, pois estes intérpretes eram conhecidos como "Línguas". A denominação "Línguas" não se refere apenas aos intérpretes com competências comunicativas através do uso de duas ou mais línguas, mas também aqueles que fornecem aos viajantes informações sobre a geografia, gentes, costumes e riquezas da região. O termo português "língua" é o predecessor de "turgimão"19, que pode ser facilmente encontrado em crônicas de viagem portuguesas do século XV e século XVI.

Neste trabalho decidimos separar a história dos truchements da história dos Línguas, pois suas origens são distintas e suas ações no âmbito da colonização europeia são totalmente

\footnotetext{
${ }^{19}$ O Língua. Disponível em: <http://cvc.instituto-camoes.pt/olingua/01/lingua2b.html>. Acesso em: 15 fev. 2016.
} 
opostas. Enquanto os truchements se preocupavam em frear o avanço da colonização francesa, os Línguas - portugueses ou mamelucos, contribuíram para a solidificação da colonização portuguesa e para a catequese dos índios.

Após esta breve introdução à história dos primeiros intérpretes do Brasil Colônia e seus modus operandi, trataremos no tópico a seguir a relação entre as línguas presentes no Colóquio entre as gentes do país, o Tupinambá original de 1580 e a língua francesa do século XVI. Entendemos que é muito importante situarmos o estado destas línguas para podermos desenvolver uma discussão sobre a conversão linguística da oralidade dos índios Tupinambá à língua escrita no Colóquio.

\subsection{UMA NAÇÃO PLURILÍNGUE}

Neste trabalho buscamos informações sobre o estado da língua Tupinambá original em 1580, da língua portuguesa durante o período colonial e da língua francesa do século XVI. A partir destas abordagens, pretendemos demonstrar os diferentes níveis de complexidade que envolvem aspectos de: status enquanto língua, sintaxe, vocabulário, nível de maturação e relevância histórica. A revelação destes aspectos são fatores determinantes para compreendermos como eles influenciam a tradução da língua Tupinambá para o francês, e posteriormente, para o português. Estas línguas, que representam realidades tão distintas, retratam o espaço-tempo aqui abordado - Brasil, nos idos do período colonial — cada uma trazendo informações diferentes em sua própria estrutura sobre um objeto de estudo em comum: a língua e a cultura dos índios Tupinambá no século XVI. O estudo sobre a história dessas línguas contribui para o entendimento do projeto etnolinguístico de restauração e retradução, na medida em que consideramos que este projeto trata das relações que as línguas possuem com suas respectivas culturas e, consequentemente, com suas visões de mundo.

Na obra, Línguas Brasileiras, para o conhecimento das línguas indígenas (1986), Aryon Rodrigues apresenta a história da língua Tupinambá, também conhecida como Tupi Antigo ou Língua Brasílica, cujo uso se firmou, sobretudo ao longo do século XVII ${ }^{20}$. Esta língua predominava nos contatos entre índios e portugueses durante os séculos XVI e XVII, já que era a mais falada ao longo da costa atlântica. No século XVI, a Língua Brasílica passou a ser aprendida pelos portugueses quando eles ainda representavam uma minoria no território brasileiro. Muitos destes portugueses passaram a viver com as mulheres indígenas e tiveram

\footnotetext{
${ }^{20}$ Cf. RODRIGUES, A.D. (1986:100)
} 
filhos, estas crianças tiveram como referencial de língua materna a Língua Brasílica. Este quadro de miscigenação se tornou cada vez mais comum nas áreas afastadas do centro administrativo da Colônia, como a Bahia, onde o uso da Língua Brasílica foi intensificado e generalizado como língua comum entre os portugueses e seus descendentes predominantemente mestiços - e escravos africanos. Em contrapartida, no centro administrativo, a crescente imigração portuguesa gerou graves conflitos com os índios, resultando na dizimação destes.

O nome Tupinambá, como designação dessa língua, aparece tardiamente, no século XVIII, com a intenção de distinguir a língua dos índios Tupinambá do Pará, da língua corrente da população mestiça; Já o nome Tupí se torna usual somente no século XIX, quando já tinha desaparecido a grande maioria dos índios Tupinambá, restando poucos remanescentes, como os Tupinikín (Tupiniquim) do Espírito Santo, de quem o Imperador D. Pedro II anotou algumas palavras, ou os Potíguara da Baía da Traição, na Paraíba. De acordo com Rodrigues (1986:100), "esses dois grupos de remanescentes subsistem até hoje, mas agora só falam a língua portuguesa". A língua Tupinambá encontrou um espaço no âmbito da escrita com a publicação de gramáticas e vocabulários elaborados por missionários jesuítas. A obra mais reconhecida sobre esta língua é a do Pe. José de Anchieta.

Em 1595, Anchieta publicou a primeira gramática da língua Tupinambá, intitulada Arte de gramática da língua mais usada na Costa do Brasil. Esta gramática foi concluída no breve prazo de seis meses, a pedido do superior da Companhia de Jesus no Brasil. Desde 1554. Anchieta se dedicava ao ensino da gramática, assim como falava e compreendia perfeitamente a língua Tupinambá. Há uma hipótese de que um manuscrito de sua gramática teria sido entregue, em 1555, aos missionários recém-chegados na Bahia para que fossem instruídos na língua indígena. Desde 1556, a gramática já servia como "texto para o ensinamento do Tupi no colégio da Bahia e, em 1560, o Pe. Luís da Grã tornou seu estudo obrigatório" (DAHER,1999:232). Em relação à gramatização das línguas indígenas Andrea Daher considera que,

De um modo geral, a publicação de catecismos e gramáticas em línguas indígenas americanas, ao longo dos séculos XVI, XVII e XVIII, pelas ordens missionárias, sugere que o uso gramaticalizado e dicionarizado dessas línguas era condição para a conversão religiosa (Daher, 1999:81).

Deste modo, entendemos que a gramatização e dicionarização das línguas indígenas acarretou uma redução linguística, por meio da simplificação e ressignificação de suas estruturas, para que se adequassem a uma escrita voltada ao propósito da catequese, com o ato 
de confissão de culpa, e consequente conversão à fé católica. De acordo com Daher (2004:81), a catequese "estaria, então, fundamentalmente ligada à escrita: produzir e estruturar a consciência do índio, sua forma de conteúdo e sua forma de expressão. Daí a possibilidade da "redução" gramatical das línguas indígenas e da produção de gramáticas e vocabulários". Neste sentido, o estudo da língua indígena se tornou para os missionários um método para realizar a catequese, com a colaboração de crianças indígenas ${ }^{21}$, que instruídas na gramática, serviam de intérpretes aos missionários e contribuíam para a conversão de outros índios.

Considerando que a língua Tupinambá adquiriu o status de Língua Geral somente a partir do século XVIII, estudaremos a seguir como se deu a transição do uso desta língua, e de outras línguas indígenas presentes no território brasileiro, para o uso obrigatório e oficial da língua portuguesa em todo o Brasil.

O Diretório dos Índios ${ }^{22}$, editado em 1755, por Marquês de Pombal, Ministro de D. José I, e que entrou em vigor em 1757, foi uma lei inicialmente direcionada às povoações de índios do Pará e Maranhão, mas, posteriormente, se estendeu a todo o território brasileiro. De acordo com Francisco Cancela (2013:45), a criação do Diretório foi motivada pelo "contexto dos conflitos territoriais entre os impérios espanhol e português, refletindo, por isso, uma política que pretendia incorporar as populações indígenas nas ações de ocupação e defesa dos territórios coloniais lusitanos", transformando os índios em súditos do rei de Portugal convertidos ao catolicismo. O Diretório promoveu grandes mudanças nas relações entre índios e não índios, estimulou a presença de não-índios nos aldeamentos e incentivou a miscigenação. Ele estipulou, em primeiro lugar, a restituição da liberdade dos índios ao extinguir os trabalhos missionários que exerciam poder sobre os aldeamentos indígenas, o que culminou na expulsão dos jesuítas em 1759. Segundo o que ficou conhecido como o "Diretório pombalino", os aldeamentos deveriam ser reconhecidas por nomes portugueses e administradas por um governo civil e os índios deveriam adotar, igualmente, um sobrenome português.

A política indigenista contida no Diretório possuía diversas rupturas, entre elas a extirpação dos costumes indígenas, que funcionava como um mecanismo de "civilização" dos povos indígenas (CANCELA, 2013:47). As reformas de costumes determinadas pelo Diretório Pombalista incluíam uma série de proibições: nudez, consumo de bebidas alcoólicas

\footnotetext{
${ }^{21}$ Cf. DAHER, Andrea, 1999:247.

${ }^{22}$ Ver anexo A.
} 
nativas, habitações coletivas e, principalmente, falar a Língua Geral. Neste sentido, Rita Heloísa de Almeida (1997) discorre sobre a situação da língua portuguesa durante o período de colonização:

O Diretório dos Índios foi decisivo na mudança linguística que se operou no Brasil no final do século XVIII. Antes desta sua intervenção, a língua geral, ou nheengatu, era comumente falada por todo o Brasil, e o português só se falava em poucos principais centros. Em poucas décadas, este entrou em decadência, mantendo sua importância apenas no estado do Amazonas. Em São Paulo, no início do século XIX, a população já se utilizava quase que somente do português, ao contrário dos três séculos anteriores. (ALMEIDA, 1997:23)

Esta língua popular usada por índios missionados e aculturados e não-índios na Colônia recebeu o nome de Língua Geral. Esta situação forçou a coroa a impor o uso da língua portuguesa em seus domínios. Elisa Frühauf Garcia (2007:26) esclarece que "além dos idiomas indígenas, nesta época também vigoravam línguas africanas, amplamente usadas pelos escravos e seus descendentes", o que também representava certo obstáculo a implantação de uso exclusivo da língua portuguesa. No entanto, cabe pontuarmos que estas línguas africanas não sofreram uma política de extinção neste período porque seu uso não era tão comum quanto o da Língua Geral. O objetivo principal de impor o uso da língua portuguesa aos índios foi de transformá-los em vassalos do rei de Portugal, para garantir o domínio territorial dos lusitanos. O aprendizado da língua portuguesa se deu com a obrigação de seu ensino nas escolas, as quais os índios deveriam frequentar para aprender sobre o cristianismo e os hábitos ocidentais. Uma vez que os índios falassem a língua portuguesa, haveria a comprovação efetiva da ocupação lusitana no território brasileiro.

Para Rodrigues (1986:21), "uma das consequências da prolongada convivência entre o índio Tupinambá e o português foi a incorporação de um número considerável de palavras da língua Tupinambá à língua portuguesa". Se considerarmos uma amostra de aproximadamente mil nomes brasileiros populares de aves, um terço, cerca de 350 nomes são oriundos do Tupinambá. Em nomes populares de peixes, dentro de uma amostra de 550 palavras, quase a metade (225 ou 46\%) veio da língua indígena. Os portugueses nomearam ainda diversos lugares com nomes Tupinambá (topônimos), onde os próprios índios nunca chegaram a viver. $^{24}$.

${ }^{23}$ ALMEIDA, Rita Heloísa de. O diretório dos índios: um projeto de "civilização" no Brasil do século XVIII . Brasília: Editora UnB, 1997. Disponível em: 〈http://www.nacaomestica.org/diretorio dos indios.htm>. Acesso em: 19 jun. 2016.

${ }^{24}$ Ibid.: 21 
A partir destas informações, observamos que a relação entre a língua portuguesa e a língua Tupinambá persiste até hoje através das palavras incorporadas desta língua indígena ao português do Brasil. No século XVI calcula-se que existiam aproximadamente 1270 línguas no território brasileiro. Esta informação reforça o caráter plurilíngue da nação brasileira no idos do período colonial. De fato, o plurilinguismo foi um dos fatores cruciais que contribuiu para a formação dos truchements, a fim de facilitar a intermediação das relações comerciais entre índios e franceses.

Veremos a seguir uma breve introdução ao estado da língua francesa no século XVI, a fim de estabelecermos algumas diferenças estruturais entre a língua Tupinambá e a língua francesa, e discutirmos a elaboração da escrita bilíngue do Colóquio.

Os franceses tentaram colonizar o Brasil em duas grandes oportunidades, mas falharam. A primeira grande colônia francesa na Baía de Guanabara, conhecida como França Antártica, liderada por Villegagnon - a quem Jean de Léry direciona muitas críticas por causa da perseguição religiosa que sofreu no período em que esteve no Brasil —, foi frustrada logo no século XVI, em 1567, ao se deparar com as forças coloniais portuguesas lideradas pelo Governador Geral Mem de Sá. A presença dos franceses acabou não resistindo à forte pressão dos conflitos oriundos da disputa territorial entre portugueses e espanhóis. Este foi um dos motivos pelos quais a língua francesa não se solidificou no território brasileiro neste período. De acordo com nossos estudos, observamos que durante o período que estiveram no Brasil, os franceses se preocuparam mais em aprender e anotar a língua dos índios Tupinambá do que impor a sua própria língua. Sobre este assunto Andrea Daher discorre que,

\begin{abstract}
A marca das relações amigáveis franco-tupis, caracterizadas e intermediadas pelos truchements, encontra-se registrada no corpus de relatos franceses sobre o Brasil, onde a inscrição da língua tupi - na forma de diálogos, de palavras soltas de orações ou de discursos traduzidos - é maciça. A partir dos textos produzidos pelos missionários capuchinhos - considerando, particularmente, a transposição gráfica do tupi nessas obras -, é possível se entender os usos da língua como instrumento político e apostólico no interior do projeto colonizador francês. (DAHER, 2004:73)
\end{abstract}

A partir deste comentário de Andrea Daher, entendemos que esta estratégia de inscrição da língua Tupi, que inteirava um projeto colonizador, reforçava laços amigáveis entre franceses e índios. Isto não quer dizer que o projeto de imposição da língua francesa não estava implícito, mas é bem provável que os franceses não tenham tido tempo hábil para estabelecê-la porque suas duas tentativas de colonização falharam. Apesar disto, consideramos pertinente estudar o estado da língua francesa no século XVI, porque ela é a primeira língua para a qual o Colóquio em língua Tupinambá foi traduzido. Assim, 
entendemos que obter informações sobre a estrutura da língua francesa neste período, nos auxiliará a estabelecer um parâmetro para realizar uma crítica produtiva das traduções brasileiras do Colóquio, porque assim já teremos em vista as estratégias aplicadas na primeira tradução. Discutiremos a seguir qual o estado da língua francesa no momento da escritura e publicação da obra de Jean de Léry, e qual efeito produz sobre o discurso francês no Colóquio.

A língua francesa falada no fim da Idade Média e no Renascimento entre os séculos XIV e XVI é denominada moyen français. De acordo com R. M. R. Bessa (2011:148), em seu artigo intitulado: A língua francesa em roteiros de navegação do século XVI: Le grand routier de mer, "com o advento da Guerra dos Cem Anos (1339-1453), o sentimento nacional francês foi fortalecido, e o povo se aliou ao rei. Esta necessidade de constituição de uma nação despertou o desejo de uma unidade linguística". O início da concretização deste desejo veio a ocorrer somente no ano de 1539 - quando a língua francesa foi oficializada como a língua do Estado através do Decreto de Villers-Cotterêts, criado em 25 de Agosto de 1539, pelo Rei François I (Francisco I). Este decreto tornou o uso da língua francesa obrigatório nos atos oficiais. Esta foi uma decisão importante no que diz respeito à centralização do poder monárquico. Este mesmo decreto obrigou os padres de cada paróquia a criar um registro para os nascimentos, este ficou conhecido como o início do estado civil.

O francês começou a ser empregado nos setores que outrora eram reservados ao latim. Assim, como mostra Rita M. R. Bessa (2011), este decreto real fez do francês a língua do Estado, o que afrontou diretamente o latim usado pela Igreja Católica, e o ensino da Sorbonne, "grande centro mantenedor do latim como língua de cultura, desde o século XIII, foi ameaçado pela criação do Collège de France (1530), onde o ensino era ministrado em língua francesa" 25 . A Igreja católica fez grande resistência a este decreto. Em contrapartida, a Reforma Calvinista (1541) contribuiu para a difusão da língua francesa, ao utilizar "o francês em língua do culto e do ensino cristão, fato reforçado pela já existente Bíblia traduzida para a língua francesa $(1535)^{126}$.

Com a invenção da máquina de impressão tipográfica por Johan Gutenberg em 1430 (séc. XV - início do Renascimento), a língua francesa conheceu sua grande difusão, de maneira que os gráficos lucravam muito mais com a impressão de livros em francês do que em latim, por causa do número significativo de leitores desta língua. Foi também no século

\footnotetext{
${ }^{25}$ Ibid.: 150

${ }^{26}$ Idem
} 
XVI que os primeiros dicionários impressos apareceram, o que contribuiu largamente para a normalização da língua francesa.

O humanismo foi um movimento muito importante para o crescimento da língua francesa no território nacional porque instigou a individualidade do homem. Por meio deste ideal de individualidade, o francês deu início à sua emancipação como língua nacional. Até o século $\mathrm{XV}$, o latim ocupava contextos de comunicação de prestígio, mas na vida cotidiana se falava os dialetos galo-romanos (inclusive o francês). Porém, com o surgimento de novas ideias, noções e até mesmo objetos que precisavam de uma denominação, o latim foi preenchido por palavras modernas disfarçadas com uma terminação latina. Ao tentarem reestabelecer o latim em toda a sua pureza, incapacitaram seu uso como instrumento do pensamento da época. Assim, o humanismo contribuiu para firmar o privilégio da língua francesa. Ela se inseriu pouco a pouco, com um movimento uniforme, em todos os setores. Houve resistência por um longo tempo, até mesmo no século XVI, mas este movimento da língua francesa já não podia mais ser impedido (WARTBURG: 1962:144).

$\mathrm{O}$ individualismo nacional pregado pelo humanismo despertou nos franceses uma reação contrária à inserção de elementos estrangeiros na língua francesa (WARTBURG, 1962:152). Durante o século XVI, os franceses combateram as influências dos latinismos e da língua italiana, conseguindo suprimir muitas palavras que eram comuns na língua no século $\mathrm{XV}$, mas, no final do século XVI, incorporaram novamente outros empréstimos do latim para enriquecer a língua francesa ${ }^{27}$.

Dez anos após a apresentação do Decreto de Villers-Cotterêts, o poeta Joachim Du Bellay, junto aos membros do grupo intitulado La Pléiade, apresentaram, em 1549, o manifesto "Deffence et illustration de la langue françoyse", onde argumentava que a língua francesa não era adaptada à expressão poética e, que, portanto, ela seria enriquecida através da criação de neologismos originados do latim, do grego e das línguas regionais. Assim, a Pléiade exerceu um papel de extrema importância na maturação do francês. Esta foi a doutrina da liberdade individual proclamada pelo Renascimento, que teve um efeito importante sobre o desenvolvimento do vocabulário francês ${ }^{28}$.

De acordo com Walter Von Wartburg (1962:150), "até então só se havia estudado gramaticalmente o latim". Isto começou a mudar em 1550, com a publicação valorosa da gramática de Louis Meigret "Le Tretté de la grammère françoèze", porque ela já continha os

\footnotetext{
${ }^{27}$ Cf. WARTBURG, Walter Von. 1962:153

${ }^{28}$ Idem.
} 
principais elementos da língua francesa ${ }^{29}$. Em relação à sintaxe, Wartburg (1962:157) destaca que o francês rejeitava frequentemente o uso do sujeito após o verbo, então a norma SVO ganhou espaço. No século XVI houve também uma retomada pela supressão de pronomes e o aparecimento de várias conjunções, por exemplo: aussi que, car, considéré que, etc; algumas destas conjunções chegaram a desaparecer no século XVII.

O século XVI na França foi marcado por uma grande liberdade, que foi corrompida pela desordem e a anarquia. A França demorou a absorver a nova humanidade que foi introduzida no Renascimento. Então, quando a França ainda não havia se situado entre o tempo antigo e o novo, e ainda não tinha encontrado sua identidade neste mundo renovado, o movimento da Reforma protestante entrou no país. O embate entre o Renascimento e a Reforma gerou uma guerra civil que durou trinta e seis anos ${ }^{30}$.

Considerando as informações sobre o estado das línguas Tupinambá, portuguesa e francesa, inferimos que, no século XVI e XVII, a língua Tupinambá usufruiu de um privilégio demográfico e territorial, que permitiu sua classificação como uma Língua Geral no século XVIII. Porém, a partir do Diretório Pombalino, assistimos a vitória da língua portuguesa sobre a língua Tupinambá, da qual ela tomou alguns empréstimos. Neste caso, o estado da língua Tupinambá passou de língua privilegiada ao substrato em relação à língua portuguesa. A situação da língua francesa é oposta à da língua Tupinambá: ela passou do estado de uma língua sem privilégio de comunicação - porque disputava espaço com outros dialetos e o latim -, ao estado de uma língua que inicia sua emancipação nacional, vencendo o latim e incorporando muitos empréstimos desta língua.

A partir desta introdução ao estado da língua francesa no século XVI, observamos que, embora a língua Tupinambá tenha recebido uma gramatização no mesmo século que a língua francesa, suas gramáticas foram elaboradas por motivos diferentes. Enquanto, a gramática da língua francesa surgiu para estabelecer um valor ao estudo gramatical, ordenar as grandes mudanças que eram constantes na língua, e o desejo de fixar certas regras; a língua Tupinambá era ágrafa — não se expressava através da escrita, e foi modificada até se adequar a uma homogeneização dos signos linguísticos. À língua indígena, foi atribuída uma consciência ocidental que não lhe pertencia. Quando uma consciência escrita foi imposta a ela, não consideraram "o índio não conhecia as convenções que permitiam distinguir os

\footnotetext{
${ }^{29}$ Cf. WARTBURG, Walter Von. 1962:150.

${ }^{30}$ Ibid.: 167
} 
gêneros, estilos e formas textuais, e ele não usava sua memória como o homem ocidental" (DAHER, 1999:243, tradução nossa). Sobre a escrita da língua Mattoso Câmara discorre que,

\begin{abstract}
A língua escrita é o que essencialmente distingue as línguas de civilização das línguas ditas primitivas, estabelecendo novas condições de comunicação linguística, que vão afetar o próprio intercâmbio oral espontâneo. A civilização se desenvolve precipuamente sob o signo da língua escrita; e não recriam as verdadeiras condições linguísticas das sociedades primitivas ou "ágrafas". Ora, a disciplinização e a literatura catequética do Tupi lhe deram uma língua escrita e até literária, e é essa língua escrita de que a tupinologia cogita. (CÂMARA, 1977:106)
\end{abstract}

A diferença fundamental entre as línguas indígenas e as línguas de civilização é a forma como se produz a linguagem. "No caso das línguas indígenas, elas funcionam apenas no aspecto do uso cotidiano das línguas de civilização. A língua indígena fíca envolvida pela situação, e é auxiliada pela mímica, o que torna as expressões linguísticas fragmentárias e insuficientes por si mesmas" (CÂMARA, 1977: 92). A partir desta introdução à história da gramatização das línguas Tupinambá e francesa, trataremos no tópico a seguir, o encontro destas línguas no Colóquio entre as gentes do país, no âmbito da conversão linguística da língua Tupinambá.

\title{
1.4 A ESCRITA DO COLÓQUIO ENTRE AS GENTES DO PAÍS
}

Neste tópico abordaremos o processo da escrita e da tradução do Colóquio, publicado na obra de Jean de Léry em 1580. A partir destas abordagens, discutiremos a conversão linguística da oralidade à escrita da língua Tupinambá e analisaremos a realização da primeira tradução do Colóquio.

Colóquio é uma palavra de origem latina (colloquium), definida segundo o dicionário Caldas Aulete ${ }^{31}$, como "conversa ou debate que aborda uma determinada questão (religiosa, cultural etc.) para elucidar dúvidas, conciliar divergências etc.". De acordo com Juan Antonio Gonzalez Iglesias (2001:4), em seu estudo sobre o gênero do diálogo com base no glossário de Codex Amplonianus 42, "Se ha reservado el término 'diálogo' para el género literario. En cambio, el género del discurso lo hemos denominado 'conversación', y más específicamente 'coloquio' como conversación centrada en un determinado tema". Neste sentido, assumimos que ambos conceitos apresentados acima se completam e caracterizam a escrita do Colóquio entre as gentes do país reproduzido por Jean de Léry. Portanto, por aglutinação de definições,

\footnotetext{
${ }^{31}$ Colóquio In: Dicionário Caldas Aulete. Disponível em: < http://www.aulete.com.br/col\%C3\%B3quio>. Acesso em: 23 de out. 2016
} 
o Colóquio deve ser entendido neste trabalho como um gênero de composição literária sob a forma de diálogo.

O Colóquio entre as gentes do país é um trabalho documental do século XVI publicado originalmente na França em 1578. Este Colóquio é composto por 212 diálogos que tratam da recepção de viajantes franceses por um anfitrião indígena no aldeamento dos índios Tupinambá. Os diálogos incluem, principalmente, frases de comunicação do cotidiano do aldeamento, observações gramaticais sobre pronomes e verbos, nomes de animais, plantas e objetos culturais. De acordo com Rodrigues (2009:43), "tais observações gramaticais e culturais formam o primeiro ensaio publicado sobre aspectos da gramática de uma língua indígena brasileira, a língua dos índios Tupinambá (Tupi Antigo)". Uma característica interessante do Colóquio é a sua formatação bilíngue: com a reprodução dos diálogos na língua Tupinambá, falada no século XVI, paralela à sua tradução em língua francesa do século XVI. A partir desta formatação, entendemos que reprodução do texto em língua Tupinambá se configura como o texto original, do qual parte a tradução francesa, a qual entendemos ser a primeira tradução do Colóquio.

Este é o grande destaque da obra de Jean de Léry. Sua importância é acentuada pelo conhecimento da história, etnografia, ciências naturais e notícias sobre o Novo Mundo em meados do século XVI. Entretanto, o relato deste cronista francês sobre o indígena brasileiro insere-se no contexto das ideias renascentistas em que a descoberta de um novo universo dáse mediante a "projeção de lendas que envolvem personagens de várias tradições e continentes, tais como Amazonas gigantes e antropófagos" (LESTRINGANT,1997:9). Por causa disso, algumas observações de Léry em seu relato de viagem tinham o "efeito de caricatura" com características não autênticas afetadas pelo seu imaginário e por coisas que leu e ouviu de outros viajantes/cronistas.

Ainda sim, Jean de Léry entre todos os outros cronistas é considerado, pelo antropólogo Claude Lévi-Strauss, o escritor mais imparcial em relação à descrição da cultura indígena, incluindo a descrição de rituais religiosos. Léry tem um discurso menos preconceituoso que os demais autores. "Através disto, em Jean Léry, transparece o bom calvinista. Ele prefere a carta a um texto eclesial; o texto à voz de uma presença; a origem relatada pela escrita à experiência ilocutória de uma comunicação fugidia" (CERTEAU, 1982: 218). Isto se deve ao fato de que ele não se limitava em escrever o que via, mas fazia observações de cunho científico, por exemplo, a descrição gramatical da língua Tupinambá: "O que os gramáticos nomeiam e chamam verbo pode ser dito em nossa língua fala e na 
língua brasileira guengaue (nhe'éngába), que corresponde a dizer "falação" ou "maneira de dizer" (LÉRY, 2009:264) ${ }^{32}$. Nas observações de cunho linguístico, o missionário calvinista francês permanece neutro e não inclui comentários pessoais. "Esta postura de Léry também é vista como uma confrontação ao catolicismo pregado pelos missionários jesuítas, pois ele buscava ver o índio na perspectiva humanista da Reforma" (ORLANDI, 2008:95).

Em relação ao Colóquio, trabalhamos com a hipótese de que seus autores tinham por objetivo principal, na elaboração da sua escrita, compartilhar informações coletadas ao longo do tempo em que conviveram com os índios Tupinambás, e o conhecimento da língua indígena adquirido, adaptados ao formato de diálogos para facilitar a comunicação dos franceses com os índios Tupinambá. A leitura deste Colóquio nos fornece uma experiência única referente ao contato com os prováveis discursos que permitiam a realização do escambo, o cotidiano dos índios Tupinambá, o conhecimento de seus objetos culturais, da fauna e da flora do território brasileiro no século XVI. Michel de Certeau entende que,

O outro (cap. XX), designado por Léry como o colóquio da língua do selvagem é um dicionário, ou antes um Assimil* francês-tupi. [...] a ilha Coligny, mediação entre o antigo e o novo mundo, é um lugar onde reina a divisão e a confusão de línguas. É a Babel no interior no Universo. (CERTEAU, 1982:223)

A designação Assimil de Michel de Certeau para se referir ao Colóquio, caracteriza o aspecto prático da obra, tendo em vista que se trata de um método moderno, rápido e autodidático de aprendizagem de línguas. Para funcionar como um guia de conversação, ou um guia prático de aprendizado da língua Tupinambá, o Colóquio precisou passar por uma operação de conversão linguística. Vejamos no diagrama a seguir a representação desta operação:

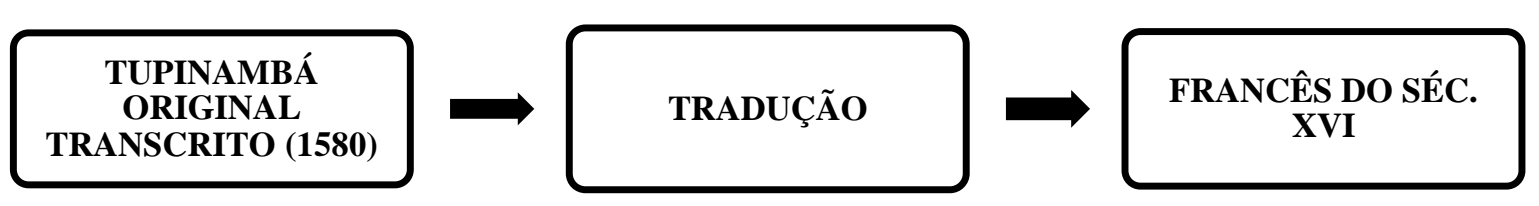

Figura 1 - Diagrama da tradução francesa do Colóquio (1580) Fonte: CESAR, Janaína T. G., 2016

A Transcrição do Tupinambá original (1580) é reproduzida a partir dos sons da língua, anotados com uma grafia francesa. Isto ocorre porque a língua Tupinambá é ágrafa, então não possui tradição de escrita. As anotações das transcrições eram realizadas pelos

\footnotetext{
${ }^{32}$ Cf. ANEXO B.
} 
truchements e pelos viajantes (marinheiros, náufragos, missionários) que conviveram ou se relacionaram comercialmente com os índios Tupinambá. A informação que temos é de que estas transcrições datam de 1540, anteriores, inclusive, à circulação do manuscrito da gramática da língua Tupinambá de José de Anchieta. Um exemplo da grafia recorrente nestas transcrições e, principalmente, no relato de viagem de Jean de Léry, é a palavra Toüoupinambaoults, que é representação da palavra Tupinambá, com o [u] sendo representado pelas letras [ou] de acordo com a regra da língua francesa;

A Tradução do Tupinambá original para o francês do século XVI foi realizada pelos truchements, com uma suposta contribuição de Jean de Léry (a qual não podemos medir quantitativamente). Esta é a hipótese que desenvolvemos neste trabalho ${ }^{33}$, mesmo que Jean de Léry tenha declarado o contrário. Identificamos nesta tradução, duas estratégias para lidar com a Realia dos índios Tupinambá: a descrição e a tradução etnocêntrica. Ambas serão abordadas neste tópico.

A operação de conversão linguística a qual nos referimos nesta pesquisa, é assim denominada por Andrea Daher para descrever o trabalho do capuchinho Claude D'Abeville. De acordo com esta operação, a conversão implica na passagem do itálico, que representa a língua indígena, aos caracteres romanos, que representa a língua para a qual se traduz. A conversão linguística consiste então: do oral ao escrito e em seguida do tupi (escrito) ao francês. Esta operação representa fielmente as mesmas etapas que identificamos na elaboração da estrutura do Colóquio. O propósito da escrita e tradução do Colóquio pode ser entendido como uma eliminação do espectro do falar indecifrável do outro (DAHER, 2004:84). Vejamos a seguir um exemplo desta conversão linguística:

(11) T. Erérou dé caramémo? As tu apporté tes coffres?

[Ils entendent aufsi tous autres vaiffeaux à tenir hardes que l'hõme peut auoir.]

A partir do exemplo acima, podemos perceber que a conversão linguística do Colóquio, inclui ainda os comentários laterais indicados entre colchetes "[ ]". As transcrições da língua Tupinambá no Colóquio "são a base do que é caracterizado como uma primeira etnografia".

Desta maneira já está aí uma realidade que lastra o enunciado de Léry. O que dele separa o Ocidental não são as coisas, mas a sua aparência: essencialmente, uma língua estrangeira. Da diferença constatada resta apenas uma língua por traduzir. Daí o capítulo que dá o código da transformação linguística (CERTEAU, 1982:223).

\footnotetext{
${ }^{33} \mathrm{Cf}$. ponto 1.2 deste capítulo.
} 
A discussão que surge a partir da conversão linguística é a transição da oralidade da língua indígena para a escrita. Andrea Daher (1999:246) afirma que "a questão central estaria estritamente ligada à escrita: produzir e estruturar a consciência do índio, sua forma de conteúdo e sua forma de expressão, 'destribalisar' para produzir consciência, constância". Embora esta afirmação possa ser válida no âmbito da gramatização das línguas indígenas, acreditamos que ela não se aplica inteiramente à transcrição da língua Tupinambá publicada no Colóquio de 1580. A transcrição da língua não tem a preocupação com a consciência ou a memória do índio, antes, visa possibilitar uma comunicação direta entre os franceses e os índios, é a busca por entender e fazer ser entendido pelo outro. Ela permite que o francês recém-chegado no Novo Mundo se adapte ao cotidiano e rotina da colônia, estabelecendo uma relação mais independente com os índios, ao negociar alimento, animais etc.

Com o processo de conversão linguística da língua Tupinambá, os franceses pretendiam torná-la inteligível e diminuir sua estraneidade para que fosse assimilada pelo viajante francês que se aventura no Novo Mundo. Esta conversão também alcança o público receptor do Colóquio na Europa, por um simples apelo à curiosidade destes pelos índios selvagens que habitam o Brasil. Este processo converge para o objetivo de facilitar a assimilação da nova realidade que se apresenta ao viajante francês, além de constituir o registro da língua Tupinambá, tal como era falado no século XVI

No que diz respeito à discussão da gramatização das línguas indígenas, a problemática se insere na imposição de tempos verbais de línguas de civilização. Mattoso Câmara (1977:91) discute que a imposição de tempos verbais às línguas indígenas, é realizada de acordo com os tempos verbais que são concebidos nas "línguas indo-europeias de civilização". A gramatização da língua foi regulada pelo modelo da gramática latina, que adulterou "as categorias genuínas e o valor dos morfemas. Os verbos passaram a ter uma conjugação à latina, mesmo que distinções como presente, pretérito perfeito, pretérito imperfeito correspondessem a uma mesma forma" (CÂMARA, 1977: 104). Os tempos verbais das línguas indo-europeias caminham em uma linha do tempo, reportando processos que se dão no presente, no pretérito ou no futuro. "O tempo assim considerado é o que muitos linguistas denominam o tempo psicológico, isto é, a ocasião do processo em referência ao momento em que se fala: o processo se deu antes desse momento, ou em concomitância com ele, ou vai se dar num momento futuro" (CÂMARA,1977:91). 
A língua Tupinambá do século XVI, antes da sua gramatização, não concebia o tempo como as línguas de "civilização". O tempo era entendido sob a categoria do aspecto verbal, que é independente de qualquer colocação temporal, e pode se expressar (se necessário) por partículas adverbiais (amanhã, logo, hoje). Assim ela concebia um processo que começava (inceptiva), terminava (conclusiva), se prolongava (durativa), ou em que a duração não é levada em conta (pontual) ${ }^{34}$. Vejamos a seguir um exemplo destas categorias:

Tabela 1 - Exemplos de aspectos verbais no Colóquio

\begin{tabular}{|c|c|}
\hline \multicolumn{2}{|r|}{ Aspectos verbais (categorias) } \\
\hline Inceptiva & $\begin{array}{l}\text { (42) T. Acepiah mo-mèn Helas ie les verrois volontiers. Como eu gostaria de vê-las! } \\
\text { (acepiác mo mã) } \\
\text { (43) F. Karamoussee Quelque autre fois. Noutra ocasião (caramocé) } \\
\text { (44) T. Tâcépiah taugé Que ie les voye prefentement } \\
\text { (tacepiác taujé) (Que eu as veja agora!) }\end{array}$ \\
\hline Conclusiva & $\begin{array}{l}\text { (149)T. Mara-pienc-pee? Et vous autres qu'eftes vous? E vocês, quem são vocês? } \\
\text { (marãpe I'áng pe'ẽ) (Como estão vocês então?) } \\
\text { (150)F. Oroicógue Nous fommes contẽs ainfi. Nós estamos contentes assim. } \\
\text { (oroicó nhẽ) (Nós estamos, simplesmente.) }\end{array}$ \\
\hline Durativa & 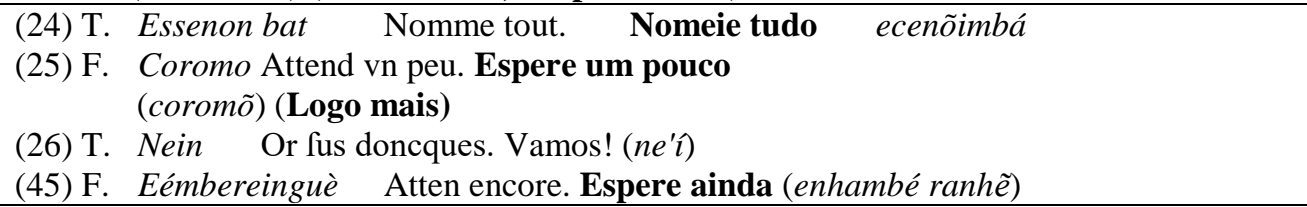 \\
\hline Pontual & $\begin{array}{l}\text { Che-roü I'ay froid. Tenho frio. (xé ro'ý) } \\
\text { Ché-racoup I'ay la fieure. Tenho febre. (xé racúb) } \\
\text { Ché-carouc-assi Ie fuis trifte. Estou triste. (xé carucacý) }\end{array}$ \\
\hline
\end{tabular}

Fonte: CESAR, Janaína T. G., 2016

A partir das informações da Tabela 1 acima, inferimos que o modo de organização do tempo da língua indígena do século XVI obedece à sua própria regra, uma regra silenciosa, mas que os europeus civilizados não compreendem e a tomam por "selvagem". Esta visão contribuiu para estabelecer uma consciência ao modo de falar do índio, com base nos modelos da gramática latina, de modo a conduzir esta língua selvagem à civilização.

\footnotetext{
Além de sua função organizadora, a gramatização da língua indígena ainda permite uma representação do exótico - como o que vem do exterior - na língua e na escrita. Quando lhe atribuímos uma gramática e quando lhe tornamos legível, sob o formato de um diálogo, [...] a língua exótica, desconhecida, deve necessariamente querer comunicar alguma coisa, uma vez que ela é suscetível de ser escrita assim como traduzida. Portadora de uma intencionalidade, além do sentido (DAHER, 1999:245, tradução nossa)
}

A partir destas considerações sobre a gramatização da língua indígena, apresentaremos no decorrer deste tópico um estudo comparativo sobre os valores dos modos e tempos verbais empregados no Colóquio, em francês e em português, que provém da tradução da língua 
Tupinambá restaurada por Aryon Rodrigues. O objetivo de realizar esta análise cinge-se na tarefa de compreendermos como os franceses interpretaram a língua Tupinambá falada no século XVI, a partir da realização de uma tradução. Neste estudo comparativo usaremos, respectivamente, a gramática de Charles Maupas (1632) e as anotações gramaticais da língua Tupinambá publicadas no Colóquio (1580), e a gramática Bechara (2009). Este estudo compreende uma amostra de 96 diálogos, que se desdobram em 127 enunciados. Esta delimitação foi definida porque estes 96 diálogos foram os únicos do Colóquio a serem restaurados e retraduzidos por Aryon Rodrigues. Sendo assim, estes diálogos constituem material pertinente para análise porque permitem verificar quais alterações existem entre a tradução francesa e a tradução em português, que têm a língua Tupinambá como mesmo texto fonte. Vejamos a seguir o gráfico que representa o levantamento dos tempos verbais empregados na tradução francesa:

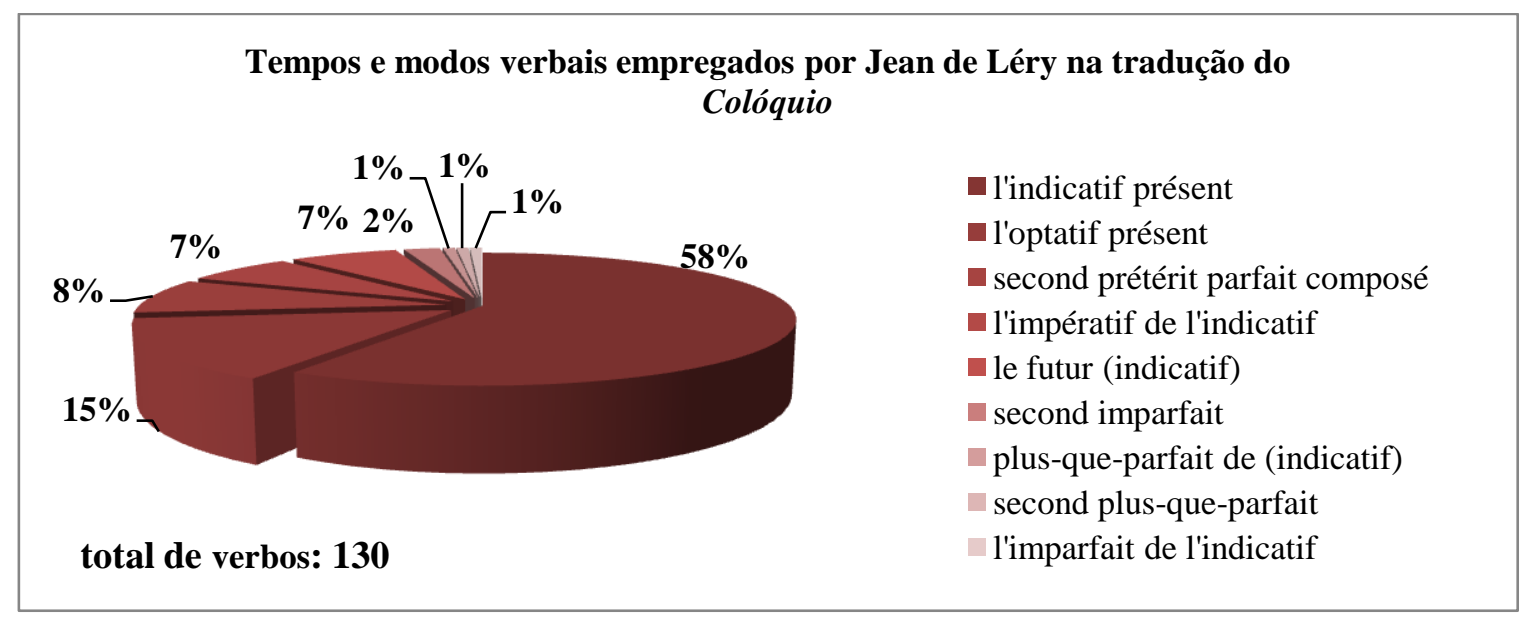

Figura 2- Gráfico de representação dos tempos verbais da tradução francesa do Colóquio (1580) Fonte: CESAR, Janaína T. G., 2016

A partir do levantamento dos tempos verbais nos 127 enunciados, identificamos 130 verbos conjugados em 9 tempos verbais, segundo a gramática francesa de Charles Maupas (1632). Mesmo que alguns destes tempos verbais possuam uma participação mínima (1\%), eles indicam 9 formas diferentes de organizar e situar a fala do enunciador. Sabemos que esta tradução francesa provém da língua Tupinambá original (1580), mas esta quantidade de tempos verbais não corresponde às observações sobre a gramática ${ }^{35}$ desta língua reproduzidas por Léry no Colóquio. Estas observações incluem 6 tempos verbais: presente (indicativo), pretérito imperfeito, pretérito perfeito, futuro, optativo e imperativo. A partir destas

\footnotetext{
${ }^{35}$ Ver ANEXO B deste trabalho.
} 
informações, identificamos a atribuição de 3 tempos verbais que não figuram nas anotações desta gramática apresentada no Colóquio, e da qual não temos identificação do autor. Estes 3 tempos verbais excedentes (second imparfait, plus-que-parfait, e second plus-que-parfait) pertencem à gramática francesa.

Nos 130 verbos identificados na tradução francesa, destacamos o uso de dois tempos verbais: indicatif présent, com 58\%, e o optatif présent, com 15\%. Tendo em vista o número expressivo dos verbos conjugados no indicatif présent, definimos o valor de seu modo e tempo, a partir da gramática da língua francesa de Charles Maupas (1632:292): "o modo indicativo define uma coisa como certeza, é a chave e o núcleo de seu uso. O indicatif présent expressa o valor de um fato, algo existente atualmente". A hipótese com a qual trabalhamos nesta pesquisa é que o uso do indicatif présent [presente do indicativo] em 58\% dos verbos representa a fala dialógica coloquial típica de um discurso de um guia de conversação, direcionado a viajantes e missionários recém-chegados no Novo Mundo, que usam destas falas para desenvolver uma comunicação imediata com os índios com o propósito de negociar objetos, alimentos e afins.

Neste sentido, entendemos que o Colóquio, enquanto guia de conversação, reproduz fragmentos de conversas e discursos reais ou prováveis (RODRIGUES, 2009:49). Estes discursos normalmente reproduzem uma situação que ocorre no presente, reforçando o seu caráter prático e objetivo. Vejamos a seguir um exemplo das falas contidas nos diálogos:

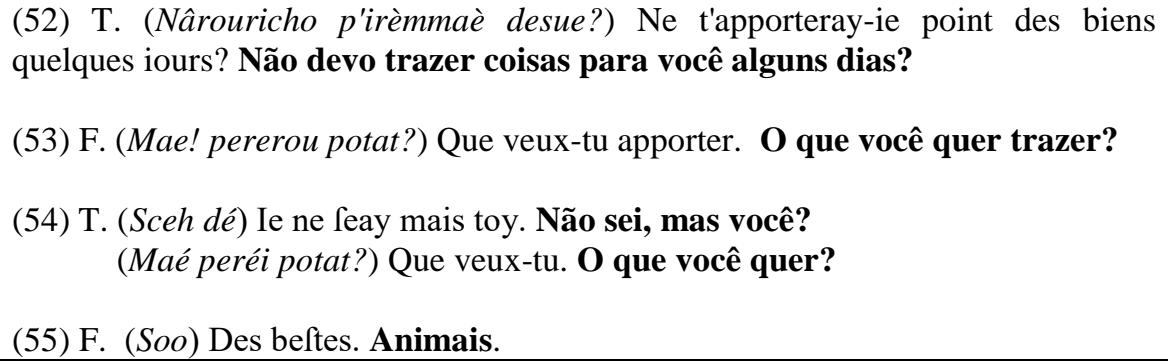

No exemplo acima, observamos que as falas dos diálogos retratam uma conversa entre o índio Tupinambá e o viajante francês, cujo assunto é a negociação de comida (animais) que o francês quer em troca dos objetos que trouxe para o índio. Estes discursos se repetem várias vezes nos diálogos para representar as variações que estas negociações por escambo podem assumir.

De acordo com as informações que vimos na Figura 2, observamos que 15\% dos 130 verbos identificados na tradução francesa estão conjugados no optatif présent. De acordo com 
as anotações da gramática publicadas no Colóquio ${ }^{36}$, o optatif tem o valor de "desejo e afeição que se tem com respeito a alguma coisa" (LÉRY, 2009:265). Este valor representa, frequentemente, os diálogos que tratam da relação dos franceses com os índios Tupinambá. Vejamos a seguir alguns exemplos desta relação expressa pelo uso do optatif présent ${ }^{37}$ :

\begin{tabular}{|c|c|c|}
\hline (99) Ty ierobah apòau ari & $\begin{array}{l}\text { Tenons nous glorieux du monde qui } \\
\text { nous cherche. }\end{array}$ & $\begin{array}{l}\text { Orgulhemo-nos da gente que nos } \\
\text { procura. }\end{array}$ \\
\hline (101) Ty rèco-gatou iendesue & $\begin{array}{l}\text { Gardons le bien C'eft que nous le } \\
\text { traitions en forte qu'il foit content de } \\
\text { nous. }\end{array}$ & $\begin{array}{l}\text { Cuidemos bem deles, isto é, } \\
\text { tratemo-los de modo que estejam } \\
\text { contentes conosco. }\end{array}$ \\
\hline (103) Ty maran-gatou apoau-apé & Soyons à ce peuple icy. & Sejamos amigos desta gente. \\
\hline
\end{tabular}

Como podemos observar nos exemplos acima, o optatif présent reflete o sentimento de afeição e desejo de uma boa relação com os franceses. O Colóquio reproduz vários discursos do que seria a fala de um índio Tupinambá se referindo à presença dos franceses no seu aldeamento. Os franceses são comumente bem vistos nestes discursos. A partir daí, inferimos que este guia de conversação demonstra a relação amigável entre as partes, que já foi confirmado por Andrea Daher (2004:83): "a marca das relações amigáveis franco-tupis, caracterizadas e intermediadas pelos truchements, encontra-se registrada no corpus de relatos franceses sobre o Brasil [...] na forma de diálogos, de palavras soltas de orações ou de discursos traduzidos". No entanto, estes discursos amigáveis no optatif présent não se aplicam às falas que tratam dos portugueses - estes discursos são feitos no indicatif présent, e os portugueses são vistos como assaltantes e raptores, por exemplo: (125) São os que derrotam aqueles que raptam os outros, isto é, os portugueses (Sont ceux qui deffont ceux qui emportent les autres, affauoir les Portugais). Por isso, elaboramos a hipótese de que o optatif présent é usado para expressar por ambas as partes (franceses e Tupinambá) o relacionamento amistoso e expressar o desejo por algum objeto que um ou outro possa possuir para realizar a prática do escambo.

Após tratarmos da tradução francesa do Colóquio, abordaremos quais foram os tempos verbais usados por Aryon Rodrigues na tradução da língua Tupinambá restaurada e quais valores estes modos e tempos verbais possuem, de acordo com a gramática da língua

\footnotetext{
${ }^{36}$ Ver ANEXO B deste trabalho..

${ }^{37}$ Charles Maupas considera o optatif présent como sendo o conjonctif, bem como Pe. Anchieta, que o denominou "conjuntivo" (fl. 22-V).
} 
portuguesa. Vejamos a seguir um gráfico que representa o levantamento de dados da tradução da língua Tupinambá para o português:

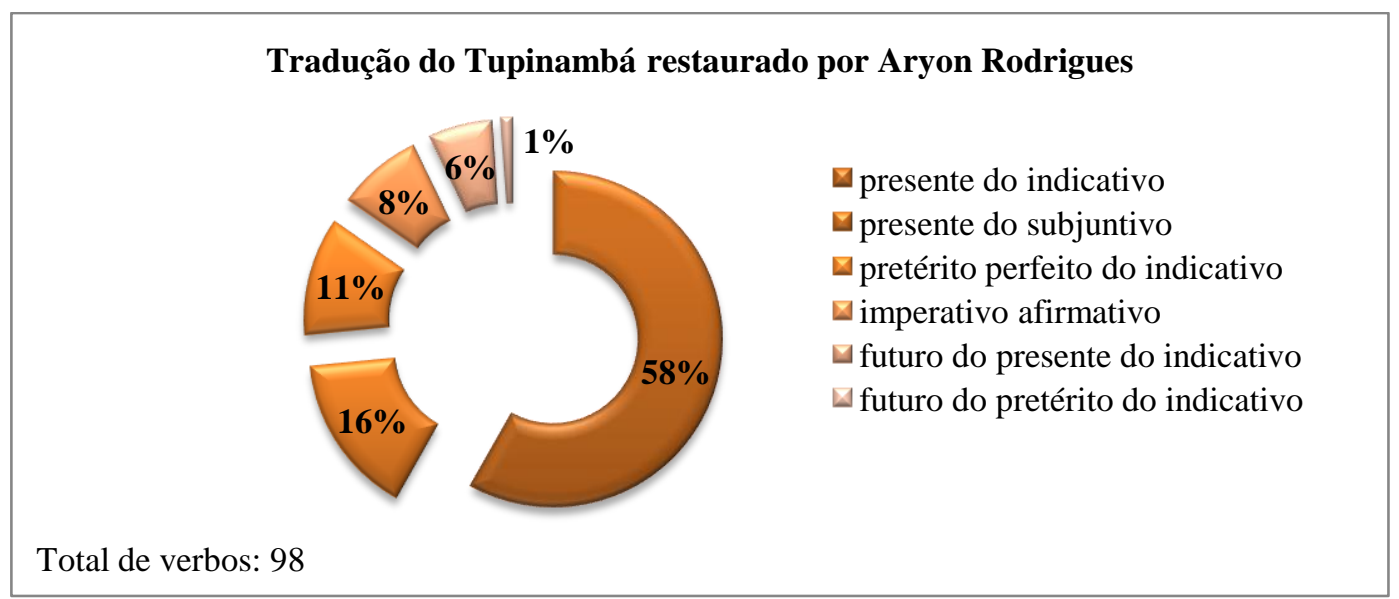

Figura 3 - Gráfico ${ }^{38}$ de representação dos tempos verbais na tradução do Tupinambá restaurado para o português. Fonte: CESAR, Janaína T. G., 2016

A partir das informações do gráfico acima, identificamos 98 verbos na tradução do Tupinambá restaurado. Dentre estes verbos, observamos o valor de 58\% que se refere ao uso do presente do indicativo - percentual que equivale ao da tradução francesa. A partir do estudo da gramática da língua portuguesa, estabelecemos que o valor do modo indicativo é o que apresenta o processo verbal ${ }^{39}$ como uma realidade, ou, que se refere "a fatos como verossímeis ou tidos como tais" (BECHARA, 2009:173). O presente do indicativo, exprime o valor da habitualidade, que expressam "fatos que se passam ou se estendem ao momento em falamos" ${ }^{40}$. Sobre este valor de habitualidade, Andrea Daher discorre que,

O tema do escambo foi, portanto, abordado por duas vezes no interior do corpus de relatos franceses sobre o Brasil, na forma de diálogo exemplar bilíngüe. Em Léry, ele aparece como uma reprodução - pretensamente fiel - de uma prática tantas vezes repetida - uma vez que os gestos implicados nas trocas comerciais estavam estreitamente ligados ao desenrolar ritual desses diálogos. (DAHER, 2004:79)

A partir do comentário de Andrea Daher, entendemos que o valor de habitualidade expresso no presente do indicativo, reflete justamente o propósito da escrita e tradução do Colóquio, a elaboração de um guia de conversação para auxiliar a comunicação dos franceses recém-chegados no Novo Mundo, e orientá-los nas negociações recorrentes do escambo.

\footnotetext{
${ }^{38} \mathrm{O}$ gráfico representado na Figura 3 é retomado na discussão das operações plurilíngues de Aryon Rodrigues no capítulo 3 deste trabalho.

${ }^{39}$ Cf. KURY, Adriano da Gama. Emprego dos modos e tempos. Disponível em:

<http://www.filologia.org.br/abf/volume1/numero1/06.htm>. Acesso em: 03 de out. 2016

${ }^{40}$ Ibid.:
} 
Vejamos a seguir alguns exemplos do uso do presente do indicativo na tradução de Rodrigues:

(149) T. Mara-pienc-pee? Et vous autres qu'eftes (marãpe I'áng pe'ê) Como estão vous? E vocês, quem são vocês? vocês então?

(150) F. Oroicógue Nous fommes contẽs ainfi. Nós estamos contentes assim. $\quad$. $\quad$ simplesmente.

F. Oree-mae-gerre Nous fommes ceux (oré ma'éjára)Nós somos os donos qui auons du bien. Nós somos os que têm das coisas. bens.

Com base nos exemplos acima, observamos que o presente do indicativo é também representativo nas comunicações mais simples, por exemplo, nos cumprimentos "como vocês estão?", e nas apresentações "como é o seu nome?". O percentual do presente do indicativo na tradução da língua Tupinambá restaurada confirma a hipótese que levantamos sobre o uso deste mesmo tempo verbal na tradução francesa: um guia de conversação contendo diálogos de caráter prático e direto.

O uso do presente do subjuntivo na tradução em português (16\%) é similar ao uso do optativo na tradução francesa (15\%). De acordo com Bechara (2009:173) "o modo subjuntivo indica fatos incertos", e apresenta o processo verbal como duvidoso, possível, ou como desejo $^{41}$. O desejo é apenas um dos valores que o presente do subjuntivo ${ }^{42}$ pode assumir, mas, assim como vimos na tradução francesa, e conferimos através do percentual (16\%) apresentado no gráfico da Figura 3, o valor do desejo se repete na tradução da língua Tupinambá para o português. Vejamos a seguir alguns exemplos da tradução no presente do subjuntivo:

(104) timomurú umè ma'éjára jandébe Não ofendamos os que têm bens para nós.
$\begin{array}{ll}\text { (106) tijeporacár aypó abá pé } & \text { Cacemos/pesquemos para essas pessoas. } \\ \text { (107) tirúr ma'é tetiruã auã pé } & \text { Tragamos de todas as coisas para eles. }\end{array}$

Estes exemplos confirmam o valor do desejo, este caso os desejos são exprimidos no sentido de agradar os hóspedes franceses, reforçando a relação cordial entre eles. Esta relação

\footnotetext{
${ }^{41}$ Cf. KURY, Op cit., 4.

${ }^{42}$ Cf. AZEREDO, 2008: "o presente do subjuntivo, segundo a gramática Houaiss, enuncia um fato que pode ocorrer no momento atual".
} 
é recíproca. Jean de Léry descreve que durante o tempo em que viveu com os índios Tupinambá, os considerava muito fiéis às suas amizades:

\begin{abstract}
Quanto à segurança dos hóspedes entre os selvagens da América, devo dizer que é absoluta; assim como odeiam os inimigos e os matam e comem quando podem, amam os amigos e aliados e não hesitam em morrer para defendê-los. Éramos amigos e aliados dos tupinambás e gozávamos, portanto de plena segurança entre eles. Fiava-me neles e me considerava mais seguro no meio desse povo, a que apelidamos selvagem, do que em França entre muitos franceses desleais e degenerados. (LÉRY, 2007:241)
\end{abstract}

A partir da análise do presente do subjuntivo, concluímos que o fato do seu valor na língua portuguesa ser similar ao dado na tradução francesa, confirma novamente uma interpretação coerente da tradução francesa para com os diálogos em língua Tupinambá.

Observamos que o uso dos tempos verbais nas duas traduções da língua Tupinambá se aproxima quanto à proporcionalidade, ao uso do presente do indicativo, do presente do subjuntivo, e de outros tempos com menor representação. Porém, este uso se distancia quando tratamos da quantidade de tempos verbais, que identificamos na amostra dos 127 enunciados que selecionamos: a tradução francesa com o uso de 9 tempos verbais; e a tradução em português com o uso de 6 tempos verbais. Visando uma análise mais objetiva, confrontamos, paralelamente, um a um, todos os tempos verbais empregados nas duas traduções com o propósito de identificarmos se os mesmos tempos verbais eram aplicados nos 127 enunciados. Vejamos a seguir um gráfico que representa a possibilidade ou não desta correspondência:

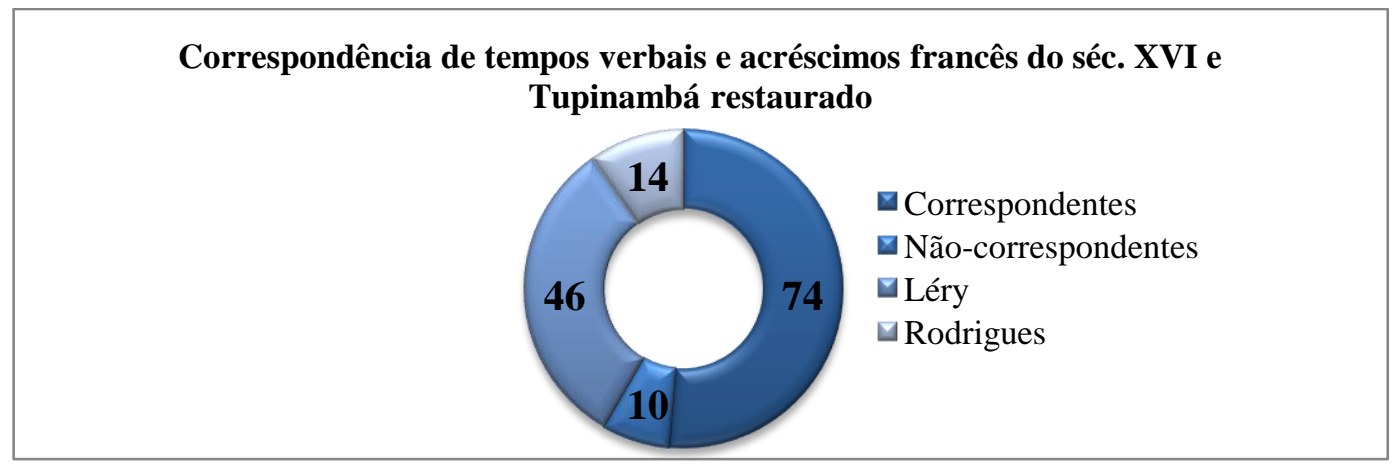

Figura 4 - Representação da correspondência dos tempos verbais nas traduções francesa e portuguesa, a partir da língua Tupinambá.

Fonte: CESAR, Janaína T. G., 2016

De acordo com as informações do gráfico acima, inferimos que a correspondência dos tempos verbais em cada enunciado representa a maioria, com 74 correspondentes. Esta informação corrobora a afirmação de Rodrigues (2009:48), de que "no confronto geral do registro de Léry com o das fontes portuguesas resulta que, na maioria dos casos, as formas são 
facilmente identificáveis, o que diz bem da legitimidade não só do seu texto, mas também da sua tradução". Tendo em vista que a tradução de Rodrigues parte do Tupinambá restaurado, e que a tradução francesa teoricamente partiria do Tupinambá original, podemos concluir que as 74 correspondências no uso dos tempos verbais, dentre os 98 verbos identificados na tradução de Rodrigues, realmente legitima a tradução francesa e refuta a afirmação de Plínio Ayrosa (2007:271), de que a interpretação francesa da língua Tupinambá seria "mais ou menos vaga". Este número também é uma comprovação de que o tradutor ou os tradutores do Colóquio realmente conheciam muito bem a estrutura da língua Tupinambá, o que só seria possível se eles tivessem um contato constante com a língua, durante certo tempo, como tiveram os truchements. Quanto aos tempos verbais não correspondentes, estes somam apenas 10.

Sobre a correspondência entre o uso dos tempos verbais do Colóquio, elaboramos uma tabela com exemplos de diálogos que representam a correspondência dos dois principais modos e tempos verbais, o presente do indicativo e o presente do subjuntivo, na tradução francesa e na tradução para o português. Vejamos na tabela a seguir esta comparação direta:

Tabela 2 - Correspondência dos tempos verbais utilizados na tradução francesa do Colóquio (1580) e por Aryon Rodrigues (2009).

\begin{tabular}{|c|c|c|c|c|}
\hline \multirow{3}{*}{ INDICATIVO } & $\begin{array}{l}\text { FRANCÉS } \\
\text { SÉC. XVII }\end{array}$ & EXEMPLOS & $\begin{array}{c}\text { PORTUGUÊS } \\
\text { SÉC. XX }\end{array}$ & EXEMPLOS \\
\hline & \multirow{2}{*}{$\begin{array}{l}\text { Indicatif } \\
\text { présent }\end{array}$} & $\begin{array}{c}\text { (4) } \\
\text { Comment te nommes tu? }\end{array}$ & \multirow[b]{2}{*}{ Presente } & $\begin{array}{c}(4) \\
\text { Como você se chama? }\end{array}$ \\
\hline & & $\begin{array}{l}\text { (21) } \\
\text { Tant qu'on ne les peut } \\
\text { nombrer. }\end{array}$ & & $\begin{array}{l}\text { (21) } \\
\text { Tantos que não se podem } \\
\text { contar }\end{array}$ \\
\hline \multirow{2}{*}{ SUBJUNTIVO } & \multirow{2}{*}{ Optatif présent } & $\begin{array}{l}\quad \text { (108) } \\
\text { Ne traitons point mal } \\
\text { ceux qui nous apportent de } \\
\text { leurs biens. }\end{array}$ & \multirow{2}{*}{$\begin{array}{l}\text { Presente do } \\
\text { Subjuntivo }\end{array}$} & $\begin{array}{l}\text { (108) } \\
\text { Não maltratemos os que } \\
\text { trocam as nossas coisas. }\end{array}$ \\
\hline & & $\begin{array}{l}\text { Efprouuons leur force } \\
\text { eftans auec nous autres. }\end{array}$ & & $\begin{array}{l}\quad \text { (124) } \\
\text { Experimentemos o } \\
\text { guerrear dessas pessoas em } \\
\text { nossa companhia.. }\end{array}$ \\
\hline
\end{tabular}

Fonte: CESAR, Janaína T. G., 2016

A partir das informações do gráfico (Figura 4), o número que nos impressiona é o da quantidade de verbos que foram acrescidos na tradução francesa da língua Tupinambá: 46, em oposição aos 14 verbos "acrescidos" por Rodrigues na tradução para o português. Na compensação final, encontramos então a diferença de 32 verbos entre as duas traduções. Sabemos que Rodrigues, primeiramente restaurou a língua Tupinambá a partir de seus conhecimentos linguísticos, e só depois a retraduziu para o português. Então, a hipótese com a qual trabalhamos é de que os 14 verbos usados por Rodrigues e que se revelaram no confronto 
das traduções, não são necessariamente acréscimos, como no sentido dos verbos da tradução francesa, mas são verbos que não foram contemplados na tradução francesa, ou seja, são verbos que foram resgatados a partir da restauração da língua Tupinambá. Esta hipótese nos leva diretamente a consideração de que o projeto etnolinguístico de Rodrigues contribui para o enriquecimento do conhecimento sobre a língua Tupinambá falada no século XVI.

Tendo em vista as considerações gramaticais que abordamos neste tópico, sobre o propósito dos tempos verbais nas traduções em francês e em português, consideramos importante mencionar que apesar da similitude entre as formas dos tempos verbais em francês e em português, o levantamento de dados na Figura 4 nos mostrou que a tradução francesa possui 32 verbos a mais que a tradução em português. Este valor é bem expressivo, principalmente em relação aos verbos empregados no presente do indicativo, que somam 76 em francês, contra os 57 em português. Esta operação resulta em uma diferença de 19 verbos, que representam, majoritariamente, a estratégia da descrição na tradução francesa dos elementos culturais, da fauna e da flora, que se referem à Realia brasileira do século XVI. Estes verbos são traduzidos por substantivos comuns na tradução em português, porque são palavras de origem tupi que já foram incorporadas ao português, então estes substantivos não causam estranhamento ao leitor brasileiro. Veja a seguir alguns exemplos desta estratégia:

\section{Diálogo 60}

C'eft vne befte grande comme vn petit couchon d'vn mois rayee de blanc \& noir. (É um animal do tamanho de um porquinho de um mês, rajado de branco e preto)

Paca [tradução a partir do Tupinambá original]

\section{Diálogo 62}

C'eft vne grande forte de perdrix ayãt le corps plus gros qu'vn chapõ.

(É uma variedade grande de perdiz com o corpo maior que o de um capão.)

Macuco [tradução a partir do Tupinambá restaurado]

A partir dos diálogos apresentados acima, podemos inferir que outro uso regular do indicatif présent na tradução francesa é o da descrição dos elementos que pertencem à Realia dos índios Tupinambá. Esta descrição é elaborada através da conjugação do verbo être no presente do indicativo - est; este verbo é classificado como verbo attributif [atributivo] (LÉPINETTE, 2002:30 ${ }^{43}$, também conhecido por verbe d'état [verbo de estado] ${ }^{44}$, que exprime um estado e permite atribuir ao sujeito uma qualidade ou característica. Esta

\footnotetext{
${ }^{43}$ LÉPINETTE, Brigitte. La syntaxe dans le grammaires pour l'enseignement du français en Espagne au XIX ${ }^{\mathrm{e}}$ siècle. Documents pour l'histoire du français langue étrangère ou seconde, n. 29, 2002. pp. $26-93$.

${ }^{44}$ Cf. L'attribut. In: Banque de dépannage linguistique. Disponível em:

<http://bdl.oqlf.gouv.qc.ca/bdl/gabarit_bdl.asp?id=4285>. Acesso em: 25 de nov. 2016
} 
estratégia de descrição é a mais comum na tradução francesa da fauna brasileira. A opção de reproduzir apenas os substantivos em língua Tupinambá e não descrevê-los na tradução francesa não pode ser cogitada, pois o público receptor do Colóquio na França do século XVI não compreenderia estes substantivos comuns: paca e macuco, se reproduzidos isoladamente, sem alguma nota ou observação. A estratégia da descrição, neste caso da tradução francesa, se apresenta como uma estratégia necessária, quando o tradutor decide manter as observações sobre a Realia brasileira sem domesticá-las.

De fato, este distanciamento linguístico e cultural entre os franceses e os Tupinambá fica mais evidente quando analisamos outra estratégia de tradução francesa para o Colóquio: a estratégia da tradução etnocêntrica. Como mencionamos no início desta pesquisa, compreendemos a tradução etnocêntrica ${ }^{45}$ como aquela que traz tudo à sua própria cultura (normas e valores), e o que se encontra fora dela pode ser anexado, adaptado para o enriquecimento da mesma. Neste sentido, entendemos que a tradução introduz representações do imaginário ocidental através de palavras originalmente inexistentes na língua tupi (DAHER, 1999:248, tradução nossa). Sobre esta relação da língua com o universo cultural, Mattoso Câmara discorre que,

Em relação à língua, o etnocentrismo ainda é maior, porque a língua se integra no indivíduo e fica sendo o meio permanente do seu contato com o mundo extralinguístico, com o universo cultural que o envolve, de tal sorte que se cria uma associação íntima entre o símbolo linguístico e aquilo que ele representa. (CÂMARA, 1977:84)

A partir deste comentário de Mattoso Câmara, entendemos que esta estratégia não é necessariamente consciente, porque o etnocentrismo está integrado na língua (meio de comunicação) do indivíduo. Portanto, este referencial etnocêntrico passa a conduzir naturalmente a observação do indivíduo sobre o universo extralinguístico e sua cultura, direcionando a criação de uma representação para o símbolo linguístico. Este referencial etnocêntrico que identificamos na tradução francesa opera através da omissão ou supressão dos elementos da Realia dos índios Tupinambá, que é traduzida por outro elemento natural à cultura do tradutor.Vejamos a seguir alguns exemplos da tradução etnocêntrica no Colóquio:

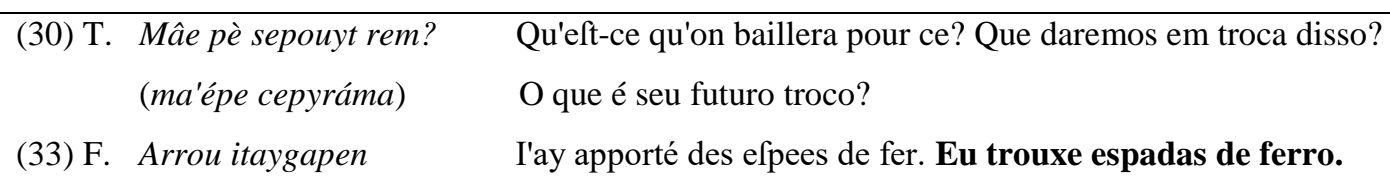

\footnotetext{
${ }^{45}$ Cf. BERMAN, A. 2007:28
} 


\begin{tabular}{|c|c|c|}
\hline & (arúr itáyapéma) & (Eu trouxe tacapes de pedra.) \\
\hline (36) $\mathrm{T}$ & $\begin{array}{l}\text { Néréroùpe guya-pat? } \\
\text { (nererúripe jyapára) }\end{array}$ & $\begin{array}{l}\text { N'as tu point apporté des ferpes à heufes? Você não trouxe foices? } \\
\text { Você não trouxe machados curvos? }\end{array}$ \\
\hline (46) $\mathrm{T}$ & $\begin{array}{l}\text { Ereroupè itaxé amo } \\
\text { (ererúpe itákycé amõ) }\end{array}$ & $\begin{array}{l}\text { As tu point apporté de coufteaux? Você acaso trouxe facas? } \\
\text { Você trouxe algumas facas de pedra? }\end{array}$ \\
\hline
\end{tabular}

Como observado, os elementos: "foices", "espadas de ferro" e "facas" que aparecem na tradução francesa do Colóquio não pertencem à Realia do indígena brasileiro do século XVI. Por isso acreditamos que esta tradução etnocêntrica se constitui por um processo de significação, ela permite que a realidade selvagem passe para o discurso ocidental (CERTEAU, 1975:232). A partir do posicionamento de crítica positiva que tomamos para esta pesquisa, devemos compreender que este processo é apenas um método para lidar com o grande distanciamento que existe entre a língua-cultura francesa e a língua-cultura dos índios Tupinambá. A partir da tradução etnocêntrica, os franceses eliminaram este distanciamento, adaptando o discurso do índio Tupinambá à realidade que eles conhecem.

O fato é que a identificação da estratégia etnocêntrica na tradução francesa só foi possível graças à restauração da língua Tupinambá por Rodrigues, realizada por meio da descrição das formas mínimas (morfemas) das palavras. A partir desta descrição, Rodrigues retraduziu o enunciado para o português, nos permitindo ter acesso a uma nova leitura do discurso do índio Tupinambá no Colóquio. Um exemplo desta restauração é o diálogo 36: néréroùpe guya-pat? "Você não trouxe foices?", Rodrigues restaura e retraduz para: nererúripe jyapára "Você não trouxe machados curvos?". Ora, a partir de uma análise inicial desta oração, identificamos a palavra jy, que significa "machado" (jyapára) (BARBOSA, 1970:134), e apara que significa "curvo, torto" (jyapára) (BARBOSA, 1951:30); identificamos também a $3^{a}$ pessoa não focal ere "você" (nererúripe), o verbo rúr "trazer" (nererúripe), a partícula de negação proclítica $n$ - combinada ao sufixo - $i$ (nererúripe), e a partícula interrogativa enclítica -pe (nererúripe) (RODRIGUES, 2010:39). Foi a partir da descrição destas formas mínimas, que Rodrigues conseguiu restaurar a oração e retraduzi-la por "Você não trouxe machados curvos?". No dicionário Tupi de Lemos Barbosa (1951), a palavra jyapara figura como um neologismo semântico para "foice", mas como veremos mais detalhadamente no capítulo 3 deste trabalho, o projeto de restauração de Rodrigues utiliza a tradução literal como método para preservar a forma da língua Tupinambá, como era falada no século XVI.. 
A partir da pesquisa realizada sobre os valores dos modos e tempos verbais nas traduções francesa e portuguesa da língua Tupinambá, entendemos que os valores estão relacionados ao projeto de escritura do Colóquio, de servir como guia de conversação para orientar viajantes recém-chegados ao Brasil e servir de auxílio à memória para os aprendizes da língua Tupinambá, os truchements. A estrutura textual dos diálogos apresentados neste Colóquio corrobora este propósito, porque as conversas do Colóquio não são todas identificadas pelo locutor T (Tupinambá) ou F (Francês), por isso supomos que estes locutores, na verdade, são hipotéticos. O fato é que dentre os 212 diálogos, 65 não possuem identificação do locutor, e estes diálogos não apresentam uma sequência lógica de conversação. Vejamos a seguir, um exemplo desta sequência de diálogos:

Tabela 3 - Exemplos de diálogos que não possuem locutores

$\begin{array}{llll}\text { (190) Ché embouassi } & \text { I'ay faim de manger } & \text { Tenho fome. } & \text { (xé ambyacý) } \\ \text { (191) Nam-che-iourou-eh } & \text { Ie n'ay point d'appetit de manger. } & \text { Não tenho apetite. } & \text { (axéjurúséi) } \\ \text { (192) Ehe-usseh } & \text { I'ay foif. } & \text { Tenho sede. } & \text { (xé ycéi) } \\ \text { (193) Ché-reaic } & \text { I'ay chaut, ie fue } & \text { Tenho calor, suo. } & \text { (xé ryái) } \\ \text { (194) Che-roü } & \text { I'ay froid } & \text { Tenho frio. } & \text { (xé ro'ý) } \\ \text { (195) Ché-racoup } & \text { I'ay la fieure. } & \text { Tenho febre. } & \text { (xé racúb) }\end{array}$

Fonte: CESAR, Janaína T. G., 2016

A partir das informações da Tabela 3, identificamos um conteúdo neutro nas frases que não possuem identificação de locutor, ou seja, elas podem ser faladas tanto pelo locutor francês, quanto pelo locutor Tupinambá. Por isso, passamos a supor que ambos são, na verdade, hipotéticos. A apresentação irregular destes diálogos (locutor presente, locutor ausente) também reforça a hipótese de que o Colóquio seria um trabalho acrescido por contribuições de outros viajantes e truchements franceses.

A hipótese inicial desta pesquisa sobre a elaboração do Colóquio enquanto guia de conversação, é reforçada pelo estudo da predominância dos tempos verbais. O presente do indicativo, que exprime uma situação real, contribuiu para uma fala dialógica coloquial, e ao mesmo tempo, para um discurso oratório dos Tupinambá. O uso do presente do subjuntivo nos diálogos do Colóquio indica a expressão de algo que se deseja ou sente, desenvolvendo um nível de profundidade nos diálogos, estabelecendo uma relação interpessoal entre os falantes.

Os resultados encontrados a partir do estudo comparativo dos modos e tempos verbais usados nos diálogos do Colóquio, publicado por Jean de Léry, revelaram uma visão expressiva e expansiva sobre o indígena. No caso da visão expressiva, vimos como o francês do século XVI traduziu a alteridade do índio Tupinambá, através da estratégia etnocêntrica e 
da descrição da Realia. A visão expansiva vem a ser o trabalho de Rodrigues, sobre a restauração da forma da língua Tupinambá, que nos trouxe conhecimento sobre os elementos extralinguísticos deste povo. Enquanto os franceses elaboraram uma documentação composta por listas de expressões usadas no cotidiano e por listas de fauna, flora e objetos, para auxiliar no contato imediato com os índios Tupinambá, Aryon Rodrigues elaborou uma tradução que provém da língua Tupinambá, restaurando elementos que foram omitidos ou adaptados na tradução francesa. A similitude entre o uso dos tempos verbais nas traduções também permitiu comprovar a legitimidade da tradução francesa dos diálogos na língua Tupinambá original (1580).

A partir dos estudos que desenvolvemos sobre a primeira tradução do Colóquio entre as gentes do país, a tradução francesa, discutiremos no capítulo seguinte, a análise crítica das traduções brasileiras para o Colóquio, sob a luz das teorias de retradução de Walter Benjamin, Antoine Berman e Yves Gambier. 


\section{CAPÍTULO 2}

\section{RETRADUÇÃO: LOCUS DO POSICIONAMENTO CRÍTICO}

A tarefa não é tanto ver aquilo que ninguém viu, mas pensar o que ninguém ainda pensou sobre aquilo que todo mundo vê. 


\subsection{RETRADUÇÃO E CRÍTICA}

Neste segundo capítulo, abordaremos os fundamentos teóricos do conceito de retradução e Crítica inseridos nos estudos de Walter Benjamin, Antoine Berman e Yves Gambier, com o propósito de investigar a trajetória das traduções brasileiras do Colóquio entre as gentes do país publicado por Jean de Léry, de modo a estabelecer se há uma relação de continuidade ou não entre elas, assim como destacar quais características influenciaram o objeto central de estudo desta pesquisa: o projeto etnolinguístico de Aryon Rodrigues para o Colóquio. No âmbito da pesquisa apresentaremos o posicionamento dos tradutores brasileiros referente a este texto de grande importância para o conhecimento da história e língua dos índios Tupinambá, que habitavam o território brasileiro no século XVI.

$\mathrm{Na}$ concepção de W. Benjamin, a tradução é compreendida como um exercício ininterrupto de conversões, "a transposição de uma língua para outra por meio de um continuum de conversões" 46 . No discurso de Benjamin, este continuum de conversões consiste na elaboração de várias versões consecutivas de um único texto original, onde o tradutor nunca alcança o estado definitivo, uma versão final de uma tradução. A partir deste conceito central, entendemos que o continuum de conversões estabelece uma relação de vida do original com a tradução, pois o texto original teria certa dificuldade em sobreviver sem a tradução, e vice-versa; isto ocorre, principalmente, porque o original e a tradução estão sujeitos ao efeito contínuo do tempo, eles envelhecem. Este é um dos motivos pelos quais retraduzimos:

é preciso retraduzir porque as traduções envelhecem, e porque nenhuma é a tradução: de onde percebemos que traduzir é uma atividade submetida ao tempo, e uma atividade que possui uma temporalidade própria: a da caducidade e da incompletude (BERMAN, 1990:1).

Este exercício de conversões, ou de metamorfoses contínuas do texto, apresenta a característica de ser ad infinitum, porque tentamos alcançar a utópica completude. É através deste continuum de conversões que se tenta atingir a afinidade entre as línguas, que na totalidade de suas intenções ascendem à pura língua e, que "demonstra-se muito mais profunda e definida na tradução" (Benjamin, 2008:69). Esta característica ad infinitum é uma consequência das constantes transformações que a língua do original e a língua materna do

\footnotetext{
${ }^{46}$ Continuum de conversões é o termo usado na tradução portuguesa de Maria Luiz Moita (1992:189); na tradução brasileira de Susana Kampff Lages, o termo é: "série contínua de metamorfoses" (cf. BENJAMIN, 2008:64).
} 
tradutor sofrem ao longo do tempo, devido a atualizações, quer seja em acordo ortográfico, novos estilos de escrita ou surgimento de novas palavras, etc.. A partir deste entendimento, consideramos que a retradução acaba por se tornar uma operação impreterível à sobrevivência do original, porque atualiza sua linguagem, que inevitavelmente se tornará obsoleta, em razão de seu envelhecimento, e da lógica que opera a sua mudança no decorrer do tempo.

A retradução foi o tema de um texto fundador de Antoine Berman, publicado em 1990, intitulado A retradução como espaço da tradução $o^{47}$. A retradução é caracterizada em um locus no qual: todo o texto posterior à publicação do original, mesmo o que for publicado na mesma língua do original, pode ser percebido como uma tradução (BERMAN, 1990:3), ou seja, todas as reescritas são percebidas como retraduções. Este locus é afirmado por Berman porque ele acredita que toda retradução compartilha uma rede de textos que em algum momento foram reescritos. Para Berman (1990:4), "toda ação humana, para se completar, precisa da repetição. E isso vale particularmente para a tradução". Neste caso, o conceito de retradução é visto de forma positiva, porque ele entende que as traduções são incompletas e que somente a partir do movimento contínuo de retradução é que se pode atingir a completude $^{48}$. Estas seriam "as grandes traduções, traduções que perduram tanto quanto os originais, as que não envelhecem, e, que chegam a brilhar mais do que eles" (BERMAN, 1990:2).

Entre Yves Gambier (1994) e A. Berman (1990) existe um ponto de contato inicial que os torna autores fundamentais na discussão da retradução no século XX: para eles, "a primeira tradução tende a ser assimiladora, reduzindo a alteridade e familiarizando aspectos linguísticos, textuais, culturais, etc." (MATTOS, 2014:45). Esta primeira tradução é caracterizada por Gambier, como um détour [desvio] do original, enquanto que a retradução vai de encontro ao texto fonte, onde há uma possibilidade em que uma segunda, terceira ou quarta leitura retorne ao texto original ${ }^{49}$. Na perspectiva de Gambier, a retradução representa o retour [retorno] à forma do original.

A partir deste conceito de Gambier, podemos exemplificar a questão da tradução em língua francesa do Colóquio, porque na primeira tradução do Tupinambá original (1580) alguns diálogos em francês foram adaptados, como estratégia do tradutor para lidar com a realia dos índios Tupinambá do século XVI. Esta estratégia também beneficiou o público receptor da obra de Jean de Léry na França. Um exemplo desta adaptação está no diálogo 183,

\footnotetext{
${ }^{47}$ Cf. BERMAN, Antoine. La retraduction comme espace de la traduction, 1990.

${ }^{48}$ Ibid.: 4

${ }^{49}$ Cf. MATTOS, 2014.
} 
onde o Tupinambá original é interpretado pelo francês por: "Faça um pouco de vinho", ao passo que, a tradução de Aryon Rodrigues a partir do Tupinambá restaurado nos mostra: "Cozinhe um pouco de cauin". Cauin é uma bebida indígena feita de mandioca, abacaxi, e, principalmente, caju, de onde se origina o nome cauin. Este é só um dos muitos exemplos de adaptação no Colóquio que reduzem o Outro em detrimento da inteligibilidade e recepção da tradução na cultura que a acolhe. Este movimento da tradução francesa é o que Gambier (1994) classifica como détour [desvio].

O valor do cauin, enquanto bebida artesanal e típica da cultura dos indígenas,foi ressignificado para "vinho" na tradução francesa, mas este valor foi restaurado, conduzido de volta ao original, a partir da restauração do Tupinambá do século XVI (caouin) por Aryon Rodrigues para kauĩ, e retraduzido para o português (cauin), o que permitiu revelar a singularidade da bebida indígena, sua estranheza, sua estrangeiridade no âmbito do espaço da retradução. Estas operações de restauração, que partiu de um conhecimento linguístico, e de retradução, que é um resultado desta restauração é o que caracterizamos como o movimento de retour [retorno] discutido por Gambier (1994), que seria o de retornar ao original, buscando a afirmação do Outro na tradução.

Igualamos estes novos conceitos introduzidos por Gambier à interpretação de Berman sobre a incompletude das primeiras traduções e a tarefa das retraduções em atingir a completude. Segundo Berman,

\footnotetext{
As primeiras traduções não são (e não podem ser) as maiores. Tudo acontece como se a secundidade do traduzir se desdobrasse com a retradução, a "segunda tradução" (de certa forma, nunca há uma terceira, mas outras "segundas"). Quero dizer com isto que a grande tradução é duplamente segunda: em relação ao original, em relação à primeira tradução. (BERMAN, 2007:97)
}

Nesta pesquisa, construímos um posicionamento de que as retraduções podem ser identificadas como uma nova leitura, interpretação e reescritura do original ou de traduções anteriores. Este posicionamento também aponta para o caráter crítico que emana do ato de retraduzir.

Segundo Berman (1995:13), a Crítica de tradução é a crítica "com C maiúsculo". Ela significa uma análise rigorosa de uma tradução, de seus traços fundamentais, o sujeito tradutor, a posição tradutória, o projeto do qual nasceu e o horizonte do qual surgiu" 50 . Berman (1995:73) sugere que "uma das tarefas de uma hermenêutica do traduzir é ter em

\footnotetext{
${ }^{50}$ BERMAN, Antoine. 1995:13.
} 
vista o sujeito que traduz". Consideramos esta colocação pertinente para a análise que desenvolvemos neste capítulo, porque traça um limite para Crítica, no sentido de que duas traduções com projetos e idealizadores/tradutores com formações e visões diferentes de trabalho, não devem ser cotejadas em uma análise crítica, porque, provavelmente, não serão encontrados traços comuns definidos, e a crítica não seria fecunda. Se estas diferenças fossem contempladas em uma análise crítica, não acrescentariam algo de produtivo uma a outra, apenas julgamentos de valor.

A partir deste conceito de Crítica elaborado por Berman, desenvolveremos as definições dos traços fundamentais de uma tradução: primeira pergunta, quem é o tradutor? Este questionamento deve ser firmemente confrontado ao modo como se produz a tradução. A busca pelo sujeito tradutor deve ser norteada por questões como: profissão, se é autor e se já publicou alguma obra, área de especialização, qual sua relação com as línguas que traduz, e por fim, se escreve sobre sua prática tradutória.

O segundo traço a ser definido é a posição tradutória: ela é "o 'compromisso' entre o modo como o tradutor enxerga a tarefa da tradução, e o modo como ele internaliza o discurso sobre o traduzir (as normas)". ${ }^{51}$ Ela é o posicionamento referente a estratégia que o tradutor produz. Neste sentido,

Todo tradutor possui certo 'conceito' ou 'percepção' do traduzir, de seu sentido, de suas finalidades, suas formas e modos. Conceito e percepção que não são completamente pessoais, já que o tradutor é efetivamente marcado por todo um discurso histórico, social, literário, ideológico sobre a tradução (e a escrita literária) (BERMAN, 1995:74).

Berman nos diz ainda que "é através da elaboração da posição tradutória, que a subjetividade do tradutor é constituída e adquire sua própria dimensão significativa". Esta posição tradutória pode ser decifrada em prefácios escritos ou entrevistas concedidas pelo tradutor.

O projeto de tradução "é determinado ao mesmo tempo pela posição tradutória e pelas exigências específicas impostas pela obra a ser traduzida" ${ }^{52}$. O projeto define, essencialmente, um planejamento de como a tradução será realizada, o que implica na definição de alguma operação. No caso da retradução de Aryon Rodrigues, veremos que o seu projeto de restauração da língua Tupinambá é concretizado por meio das operações plurilíngues, realizadas de acordo com a ordem de acontecimento do discurso no Colóquio de 1580.

\footnotetext{
${ }^{51}$ Ibid.: 76

52 Idem
} 
De acordo com Berman, "os conceitos de posição tradutória e projeto de tradução são concebidos dentro de um horizonte tradutório" ${ }^{53}$. Este horizonte se configura como "o conjunto de parâmetros linguageiros, literários, culturais e históricos que determinam o sentir, o agir e o pensar de um tradutor" ${ }^{54}$. A definição destes parâmetros é crucial para a análise das traduções, porque eles afetam diretamente a prática tradutória.

Este conceito de Crítica de tradução desenvolvido por Antoine Berman contribui para o estudo comparativo dos traços fundamentais que as traduções adquirem a partir de um projeto de tradução. Este estudo permite que analisemos objetivamente diversas traduções e retraduções de um mesmo texto, para que possamos identificar e justificar o direcionamento que os tradutores escolheram para suas traduções. Este direcionamento pode partir da apreciação de trabalhos anteriores aos deles, e influenciar uma mudança de projeto, por exemplo, do literário para o linguístico e vice-versa. Tendo em vista este caráter analítico que a Crítica nos proporciona, podemos agrupar traduções com propósitos similares e analisá-las sob a perspectiva de uma crítica produtiva.

Com base nos conceitos de retradução e Crítica, aqui abordados, apresentaremos a seguir uma análise das traduções brasileiras do Colóquio entre as gentes do país, a partir de um levantamento dos traços fundamentais que permeiam a tradução: o sujeito tradutor, a posição tradutória, o projeto de tradução e o horizonte tradutório.

\subsection{CRÍTICA PRODUTIVA: TRADUÇÕES BRASILEIRAS DO COLÓQUIO}

Segundo Berman (1995:96), a crítica produtiva ${ }^{55}$ é uma etapa "válida apenas quando uma tradução precisa imperativamente de uma retradução, seja porque apresenta algum problema, ou porque se trata de uma tradução antiga". Esta crítica produtiva indica os princípios para a organização da retradução de uma obra, inclusive, novos projetos de tradução que permitem melhorá-la. A partir desta etapa, a análise da tradução torna-se Crítica $^{56}$ no sentido mais elevado possível - uma crítica produtiva e fecunda. A partir da apresentação deste conceito positivo de Crítica, propomos demonstrar como esta etapa direciona o projeto de restauração da língua Tupinambá de Aryon Rodrigues a partir da análise dos trabalhos brasileiros de restauração e tradução anteriores ao dele. Apresentaremos

\footnotetext{
${ }^{53}$ Ibid.:79

${ }^{54}$ Idem

${ }^{55}$ Ver página 37.

${ }^{56}$ Cf.: Schlegel in: Pour une critique des traductions. (1995: 96)
} 
a seguir as primeiras traduções brasileiras do Colóquio $^{57}$. Cabe ressaltarmos que o Colóquio de Aryon Rodrigues será tratado em um capítulo a parte, porque analisaremos detalhadamente seu novo projeto de restauração e tradução da língua Tupinambá e tradução da língua francesa do século XVI.

Como vimos no capítulo anterior, o Colóquio entre as gentes do país trata da recepção de um viajante francês no aldeamento dos índios Tupinambá. Esta temática é desenvolvida no formato de diálogos apresentados em uma disposição bilíngue: em língua Tupinambá original, seguida da tradução para a língua francesa do século XVI. A partir desta informação, estabelecemos que a língua francesa do século XVI é a tradução direta da língua Tupinambá original. Portanto, o texto reproduzido em francês é entendido neste trabalho como sendo, tecnicamente, a primeira tradução do Colóquio; o que, consequentemente, estabelece uma nova percepção sobre as traduções que foram publicadas posteriormente à tradução francesa: todas passam a ser identificadas como retraduções. Neste sentido, todo texto secundário ao original pode ser analisado sob o método da Crítica, e isto inclui as retraduções (BERMAN, 1990:3).

Com o propósito de ilustrarmos o locus e o tempo que as traduções brasileiras ocupam em relação à primeira tradução, desenvolvemos um diagrama que representa a linha temporal que parte da publicação da primeira tradução e alcança todas as publicações das traduções brasileiras. Vejamos o diagrama a seguir:

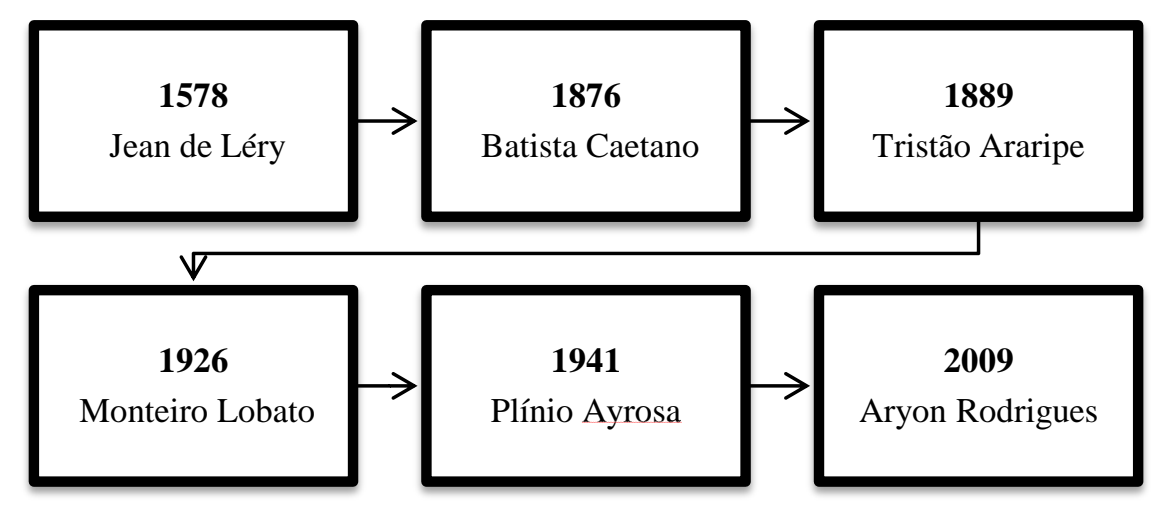

Figura 5 - Representação do distanciamento temporal entre as publicações do Colóquio Fonte: CESAR, Janaína T. G., 2016

Nas análises dos traços fundamentais das traduções brasileiras do Colóquio, procuramos assumir um posicionamento de Crítica positiva ao evitarmos julgamentos de valor direcionados ao posicionamento das traduções brasileiras. O principal objetivo deste

\footnotetext{
${ }^{57}$ Ver Figura 1 - Linha do tempo.
} 
trabalho é contextualizar os projetos das traduções brasileiras que antecedem o projeto etnolinguístico de Aryon Rodrigues, para alcançarmos, assim, uma crítica produtiva. Estas análises que faremos a seguir serão fundamentadas nos textos de acompanhamento (introduções, advertências, prefácios e posfácios) das referidas publicações. Delimitamos este recorte porque estes textos fornecem as informações mais essenciais e imediatas sobre o posicionamento, projeto e horizonte dos tradutores. Entendemos que a anotação dos discursos de acompanhamento nos permitirá uma análise mais objetiva, porque ele "amplia e reduz em um só movimento a estraneidade do texto traduzido" (TORRES, 2011:12). Este fator contribuirá diretamente para a abordagem da Crítica produtiva que se realizará entre as traduções com traços fundamentais semelhantes.

\subsubsection{Batista Caetano (1876)}

A primeira publicação brasileira do Colóquio data de 1876, no segundo opúsculo dos Apontamentos sobre o Abañeênga por Batista Caetano de Almeida Nogueira ${ }^{58}$ (1826-1882). Batista Caetano foi um poeta, filólogo, matemático, professor, funcionário público e membro do Instituto Histórico e Geográfico Brasileiro (IHGB). Na época de seu falecimento, trabalhava na construção de um dicionário da língua brasileira, que não foi publicado. Entre todas as publicações brasileiras do Colóquio, ele é o único que não propõe uma tradução da língua francesa para o português. Batista Caetano trata o Colóquio em três partes: "nota preliminar" (prefácio), "colóquio" e "explanações". Na nota preliminar, ele menciona as edições com as quais trabalhou e anuncia as operações que realizou nos apontamentos [restauração] da língua Tupinambá. Os apontamentos são, essencialmente, correções ortográficas para o vocábulo do Abañeêga, a partir do uso da gramática e do dicionário. Nas explanações, constam explicações para as frases e vocábulos "que menos facilmente se adaptarem ao idioma e por isso precisarem de alguma interpretação" (NOGUEIRA, 1876:5). Batista Caetano esclarece ainda que sua intenção não é trazer explicações etimológicas e determinação do radical, "porque estas pertencem ao diccionário".

Batista Caetano enquanto filólogo se dedicou exclusivamente à restauração e elaboração de observações sobre a língua Tupinambá do século XVI. Esta publicação é a primeira a tentar realizar esta restauração. A restauração é feita para a $5^{\mathrm{a}}$ edição francesa,

\footnotetext{
${ }^{58}$ Ensaios de Sciencia II, Rio de Janeiro, 1876. Disponível em:

<http://www2.senado.leg.br/bdsf/item/id/242810>. Acesso em: 06 jun. 2016
} 
publicada em $1611,{ }^{59}$ e para a edição latina ${ }^{60}$, da qual Batista Caetano não disponibiliza a informação sobre o número da edição. Confrontada à edição latina, a edição francesa (1611) é bem mais volumosa - fato que Batista Caetano critica veementemente, porque toma estes acréscimos por "inúteis" e que não podem ter nenhum proveito.

Este diálogo foi copiado de uma edição latina da obra de Lery, que tive em mãos por obsequio de um amigo. Anteriormente tinham sido tomadas varias notas de uma edição franceza mais antiga, e foi pena não ter então copiado o diálogo todo porque parece que n'aquella edição vinham com mais exactidão os vocábulos da LÍNGUA GERAL e enfim o livro todo conservava mais aquella ingenuidade característica com que fora escripto de principio. (NOGUEIRA, 1876:3)

Segundo Batista Caetano (1876:4), "ambas estas edições, uma por ser traduzida, outra, por ser amplificada, parecem, nas transcripcões dos vocábulos da língua indígena, menos exactas do que a primitiva". Em relação a estas transcrições, Batista Caetano questiona que se estes erros de transcrições ocorrem até mesmo em uma obra reimpressa pelo próprio autor, que dirá quando as frases e os vocábulos forem transcritos por alguém que não conhece as coisas e os nomes do livro original? Sua intenção foi de procurar conservar integralmente na transcrição a grafia de Léry "mas não foi possível assim ser in totum, porque, por exemplo, na typographia não há o s antigo e semelhante á $\int$, porque, demais, Lery não manteve orthographia uniforme e foi escrevendo, por exemplo, ora Sauuage ora sauvage" (NOGUEIRA, 1876:6). Batista Caetano (1876:4) afirma que estas falhas nas transcrições ocorrem também em relação à língua indígena reproduzida no Colóquio, e que isto ocasiona na impressão de que "há uma enorme multiplicidade de línguas" que foram atribuídas aos índios.

Batista Caetano apresenta o Colóquio com duas edições em uma formatação bilíngue: a primeira página sendo a edição francesa, e na página seguinte o texto do Colóquio em latim. Os apontamentos, que são as operações de restauração da língua, consistem nas frases e vocábulos do diálogo reduzidos à ortografia proposta para o Abañeênga. Estes apontamentos são colocados em primeiro plano na edição francesa, e no "texto original trasncripto de Lery a repetição feita entre parenthesis é a da phrase, qual se acha na $5,{ }^{a}$ edição franceza". Vejamos a seguir um exemplo desta disposição de diálogo da edição francesa:

\footnotetext{
$595^{\mathrm{a}}$ edição francesa: "Colloque de l'entree ou arriuee em la terre du Bresil, entre les gens du pays nommez TOUOUPINAMBAOULTS et TOUPINENKINS en langage sauuage et François".

${ }^{60}$ Em latim: "Colloquium in ipso aditu Brasiliensis orae inter indígenas TOUOUPINAMBAULTIOS TOUOUPINENKIN brasilicè ac latinè conscriptum".
} 


\section{Tupinamba}

Voila, bien dit. Teh! auge, nypo.

(The! auge ny-po)

A respectiva página em latim da edição francesa possui o texto corrente do diálogo, sem os apontamentos, mas com notas sequenciadas, que estão posicionadas ao lado da transcrição da língua indígena. A numeração remete às notas que se encontram nas "explanações". Vejamos a seguir um exemplo desta disposição na edição latina:

\section{Bene dixisti. Ta! aguyjé nipó. (3}

Batista Caetano admite que,

E' possível que me engane e erre na interpretação e por conseguinte na correção de orthographia dos vocábulos e das phrases, mas outro virá que conheça mais perfeitamente o ABAÑEÊNGA e corrija os meus erros. Como desculpa dos erros que possa commeter limito-me á tomar para mim as seguintes palavras do Sr. Max Müller: "não se segue de modo algum, que quando se ache a chave de inscripções antigas, se possa desde logo dar explicação precisa de cada dicção e interpretação exacta de cada phrase [...]". (NOGUEIRA, 1876:5)

Com este mea culpa enunciado por Batista Caetano, inicia-se uma tendência entre todos os tradutores brasileiros do Colóquio em assumir falhas de interpretação, deixando nítido que outros poderiam se aventurar à completar sua tarefa.

Sobre a restauração do Tupinambá realizada por Batista Caetano, Rodrigues (2009:44) afirma que a interpretação de muitas formas foi uma "tentativa bem-sucedida", considerando o fato de que Batista Caetano não teve acesso ao dicionário Tupinambá dos jesuítas (Vocabulário na Língua Brasílica - 1938), que ainda não era conhecido e não estava publicamente disponível quando sua tradução foi publicada em 1876. Por isso Batista Caetano supôs erroneamente que a língua falada na costa do Rio de Janeiro era idêntica à língua falada pelos índios Guaraní, chamando-as de Língua Geral:

Examinando-se as phrases apanhadas por Lery no Rio de Janeiro, reconhece-se imediatamente que era a LINGUA GERAL, e a LÍNGUA GERAL tal qual era fallada não só na costa, mas pelos GUARANIS no Paraguay sem nenhuma differença fundamental á não ser a da orthographia. (NOGUEIRA,B.C d A., $1876: 4)^{61}$

\footnotetext{
${ }^{61}$ Grifos do autor.
} 
Segundo Rodrigues (2009:45), "Batista as interpreta do mesmo jeito porque era bom conhecedor do Guarani Antigo, por isso se propôs a corrigir a grafia de Léry com base no Guarani Antigo". Um exemplo desta correção é: onde Léry escreveu caramémo, que significa "caixa", os missionários portugueses escreveram "caramemoã". Mas, Batista Caetano substituiu a escrita de Léry pela forma do Guarani Antigo "karámênguã". Neste caso, Rodrigues considera que, pelo fato de Batista Caetano não dominar a estrutura da língua Tupinambá, seus apontamentos nos diálogos levam a uma interpretação desconexa e pouco fiel à realidade conhecida através da historiografia dos índios Tupinambá. Ainda sim, Batista Caetano é valioso porque apresenta a operação pioneira de restauração da língua indígena, o que em si representa o estabelecimento de um primeiro parâmetro para se realizar a Crítica produtiva de Aryon Rodrigues.

\subsubsection{Tristão Alencar Araripe (1889)}

A segunda publicação do Colóquio é de Tristão de Alencar Araripe (1889) ${ }^{62}$. Tristão Araripe $^{63}$ nasceu em 7 de outubro de 1821, em Icó, na província do Ceará, foi magistrado e político brasileiro, com destaque para os cargos de Ministro da Fazenda (1881) e Ministro do Supremo Tribunal Federal (1891). Assim como Batista Caetano, Araripe foi membro do Instituto Histórico e Geográfico Brasileiro (IHGB) e publicou diversos trabalhos de literatura jurídica, e traduções sobre expedições no Novo Mundo, por exemplo: Ataque e tomada da cidade do Rio de Janeiro pelos franceses em 1711 sob o comando de Duguay-Trouin ${ }^{64}$ (1884).

Tristão Araripe foi o primeiro a traduzir para o português a obra História de uma viagem feita à terra do Brasil. Ele se propôs à tarefa de traduzir a obra de Jean de Léry em "língua vernácula", pois acreditava que "esta obra é um dos primeiros monumentos gráficos da nossa istoria primitiva, e convem encorporal-a ao, nosso peculio istorico [...] e essa encorporação convem fazer na lingua nacional" (ARARIPE, 1889:2). A publicação da obra de Léry contém uma advertência, que pode ser compreendida como um prefácio à tradução de Araripe, onde discorre sobre o que seria a indicação do seu projeto de tradução:

\footnotetext{
${ }^{62}$ Primeira tradução do Colóquio: "Coloquio da entrada ou xegada na terra do Brazil entre a gente indigena xamada Tupirambás ou Tupiniquins em linguagem selvagem e franceza"

${ }^{63}$ Tristão de Alencar Araripe. Disponível em:

<http://www.stf.jus.br/portal/ministro/verMinistro.asp?periodo=stf\&id=344>. Acesso em: 10 de out. de 2016.

${ }^{64}$ No original em francês: Mémoires de Duguay Trouin (1740).
} 
A tradução facilita ao leitor nacional a leitura, e ficarei satisfeito do enfadonho trabalho, a que me dei, se com efeito assim suceder. Procurei seguir o texto com escrúpulo, e ser exato na interpretação do pensamento do autor. Si alguém de futuro quizer confrontar a tradução e o original, corrigirá qualquer desvio, que eu tenha porventura cometido, fazendo serviço ás terras patrias. (ARARIPE, T.de A., 1889:2)

A partir do trecho da advertência acima, podemos observar que o posicionamento nacionalista de Araripe reflete diretamente no seu ato tradutório, por exemplo, quando ele traduz até o nome de Jean de Léry para João de Leri, objetivando aproximar o texto do leitor brasileiro e torná-lo acessível. Esta estratégia que se insere na operação de tradução onomástica possui uma ramificação denominada "substituição", que se configura quando o tradutor usa a convenção correspondente do nome próprio da língua fonte, na língua alvo; esta estratégia de substituição também implica na realização de alterações gráficas (VEMES, 2003:93) ${ }^{65}$. Assim, Araripe acredita que o ato de traduzir é um "serviço às terras pátrias", e bom seria se outros imitassem "tam louvavel empenho". Seguindo este ideal de democratizar o acesso à leitura de textos estrangeiros ao público brasileiro, Araripe se propôs a traduzir igualmente Hans Stan, de Andre Thevet e Alvaro Nunes Cabeça de Vaca ${ }^{66}$, que também escreveram sobre os idos da história do Brasil.

$\mathrm{Na}$ advertência que redige ao texto de Jean de Léry, Araripe descreve também as dificuldades que enfrentou ao lidar com os termos obsoletos, transposições e o estilo irregular do autor:

\begin{abstract}
Quem duvidar do que dizemos procure o original francez, e leia; e estou certo, que terá repetidamente de parar na leitura para refletir, organizar a locução e comprehender o sentido d'essa frazeologia antiquada e d'esse estilo incorreto e xeio de continuadas transpozições, que pertubam a clareza do pensamento, e interrompem a propozição principal com incidentes e circunstancias numerozas, cuja multiplicidade escurece e baralha as ideias, que se vam deduzindo no discurso. (ARARIPE, 1889:2)
\end{abstract}

Esta dificuldade em lidar com o texto de Léry claramente se dá pela escrita do francês em "antigo estilo" dominado por hipérbatos - como se refere o tradutor, e cujo trabalho de leitura envolveu o uso frequente de dicionários antigos para identificar termos em desuso (ARARIPE, 1889:2). O texto em francês ao qual Araripe se refere é o da edição de 1880 publicado em Paris e anotado por "Paulo Gafarel"67. Referente à tradução desta língua

\footnotetext{
${ }^{65}$ Cf. VERMES, Albert Péter. Proper names in translation: An explanatory attempt». Across Languages and Cultures, v. 4, n;1 , 2003, pp. 89-108. Disponível em: <http://dx.doi.org/10.1556/Acr.4.2003.1.5> Acesso em: 14 nov. 2016.

${ }^{66}$ Cf. Álvar Nuñez Cabeza de Vaca. Disponível em: <http://sevilla.abc.es/sevilla/20130821/sevi-alvar-nunezcabeza-201308141512.html>. Acesso em 14 nov. 2016

${ }^{67}$ Cf. Paul Gaffarel.
} 
francesa, Araripe se posiciona apenas por meio de uma única nota localizada no fim do Colóquio, na qual ele diz que verte o texto em francês para o português, mas não esclarece qual o método que utiliza. Retomamos, portanto, a sua citação na "advertência": "Procurei seguir o texto com escrúpulo, e ser exato na interpretação do pensamento do autor." Vejamos a seguir um exemplo desta interpretação de Araripe:

\section{Edição original (1880)}

T. Eori-deretani ouani repiac. Vien doncques voir le lieu où tu demeureras.

Tradução Araripe [1889]

T. Eori deretani ouani repiac. Vem ver o lugar, onde devemos morar. ${ }^{68}$

Como podemos ver no exemplo acima, a tradução interpretativa de Araripe inclui um sujeito elíptico na $3^{\mathrm{a}}$ pessoa do plural - indicado pela desinência -mos, que não aparece no texto em francês, que apenas se refere ao sujeito na $2^{\mathrm{a}}$ pessoa do singular $t u$ (ver nota 7 ). $\mathrm{O}$ tempo verbal utilizado por Araripe é o presente do indicativo, mas no original em francês o tempo verbal é o futur ${ }^{69}$, expressando um acontecimento que será em um futuro próximo, mas que não se passa no presente. A partir deste exemplo, podemos concluir que a tradução de Araripe ultrapassa seu objetivo de "exatidão", que a princípio nos levaria a entender que seria o de uma tradução literal.

Sobre a transcrição da língua Tupinambá, "as palavras indigenas vam escritas com a ortografia da pronunciação franceza. Si tivessemos de exprimir a pronuncia com a ortografia portugueza, fariamos alterações graficas, que disfigurariam o tipo original do autor" (ARARIPE, 1889:163). Portanto, Araripe não propõe nenhuma modificação na língua indígena para manter a forma do original, mas isto também se deve ao fato de que Araripe não possui conhecimentos linguísticos sobre a língua indígena, então não poderia realizar esta tarefa. No entanto, Araripe demonstra uma consciência linguística em sua nota ao Colóquio, onde levanta um importante questionamento em relação à representação gráfica da língua indígena e sua documentação:

A reprezentação grafica da pronuncia dos vocabulos brazilicos entre os escritores
patrios não é identica, e mostra quam diversamente percebiam a linguagem dos
nossos indigenas os primeiros exploradores, que com eles se relacionaram e os
ouviram falar. Não temos oje meio de verificar qual a verdadeira e exata
pronunciação das palavras tupicas ou guaranis, porque já não temos quem as profira
com a dição primitiva; pois faltam individuos que falem a lingua dos aborigenes,

\footnotetext{
${ }^{68}$ Diálogo anterior para referência: [1880] T. - Ere-iacasso pienc ? As-tu laissé ton pays pour venir demeurer ici ? [1889] T. Ereiacassopienc? Deixaste teo paiz para vir morar aqui?

${ }^{69}$ Ver modos e tempos verbais do francês por Charles Maupas no capítulo 1 deste trabalho.
} 
como estes a falavam nos tempos do descobrimento do Brazil. (ARARIPE, 1889:163)

Segundo Araripe (1889:118), "muitos vocabulos estam estropiados pela pronuncia figurada pêlo autor; e cada qual poderá restabelecel-os e escrevel-os conforme os escrevem os escritores nacionaes entendidos no mesmo idioma". Araripe ainda identifica algumas palavras que o autor "estropia" na escrita: onde Léry escreve, por exemplo: Arazatuve, kariauc, tapiroussou, toucouaroussoutuvi, tupen, os escritores nacionais entendidos do idioma escrevem: Aracatiba, Carioca, Pitirussú, Taquarussutuba, Tupan. Araripe não se demonstra surpreso com estas variações na escrita porque, ao seu ver, nem mesmo as língua indígenas vivas "possuem um sistema uniforme de pronunciação e ortografia ${ }^{70 "}$.

Apesar de ser o precursor da tradução brasileira da obra de Jean de Léry, a tradução de Araripe não é contemplada por Aryon Rodrigues em seu prefácio; acreditamos que isto ocorre pelo fato de Araripe não ser linguista e não propor um projeto de restauração da língua Tupinambá. Logo, a Crítica de Rodrigues não poderia ser produtiva, haja vista que Araripe e Rodrigues não compartilham do mesmo método para traduzir o Colóquio. Tristão de Alencar Araripe faleceu em 3 de julho de $1908^{71}$. Dezoito anos após seu falecimento foi publicada por Monteiro Lobato a primeira retradução brasileira do relato de Jean de Léry.

\subsubsection{Monteiro Lobato (1926)}

O distanciamento temporal entre a primeira tradução para o português de Tristão Araripe (1889), e a segunda, publicada por Monteiro Lobato em 1926, é de trinta e sete anos. A obra de Jean de Léry História de uma viagem feita à terra do Brasil é a segunda obra conseguinte que Monteiro Lobato retraduz a partir da tradução de Tristão Araripe: Araripe traduziu em 1892, Relação verídica e sucinta dos usos e costumes dos Tupinambás de Hans Staden $^{72}$, Monteiro Lobato retraduziu e publicou este mesmo texto, em 1925, com o título de Meu captiveiro entre os selvagens do Brasil.

Responsável pela edição e a nova tradução da obra de Jean de Léry, Monteiro Lobato afirma que utilizou com base a edição 1880, anotada por Paul Gaffarel, e a tradução de

\footnotetext{
${ }^{70}$ Ibid.: 118

${ }^{71} \mathrm{Cf}$. nota de rodapé $\mathrm{n}^{\circ} .12$.

72 No original em alemão, Warhaftige Historia und beschreibung eyner Landtschafft der Wilden Nacketen, Grimmigen Menschfresser-Leuthen (1557), e na tradução de Hans Staden para o francês, Véritable histoire et description d'un pays habité par des sauvages nus, féroces et anthropophages.
} 
Tristão Araripe. Neste sentido, ele redigiu em seu prefácio um elogio à tradução feita "conscienciosamente" por Araripe, mas também criticou seu modo de escrita:

Araripe escreveu numa ortographia phonetica de seu uso particular, que coisa nenhuma autorisava e só contribuiu para deixar Lery ignorado dos leitores indígenas. Alem da absurda graphia, precursora das reformas arbitrarias que a nossa Academia de Letras tentou e o governo de Portugal impoz, a divulgação da obra viuse também obstada pelo literal da traducção, dessas que transpõem para outro idioma todos os defeitos de fórma do original. (LOBATO, M.,1926:V)

Ora, como vimos no ponto anterior, a tradução de Tristão Araripe se autodenomina literal, mas isto não se reflete na tradução do Colóquio. Apenas um estudo mais aprofundado de sua tradução poderia apontar se suas interpretações constituem uma estratégia literal ou livre, de caráter minoritário ou representativo. Um ponto em comum entre estes dois tradutores é que ambos criticam a escrita de Léry; a todos os pontos já mencionados por Araripe, Monteiro lobato acrescenta que "seu stylo vale por carrascal encipoado e espinhento, do que exige picadas a facão." Mesmo com essa forte crítica, Monteiro Lobato afirma que o que lhe interessa é o que Léry conta:

\footnotetext{
Saint Hilaire o appelidou o Montaigne dos viajantes', e não errou pois é de louvar em Lery a sua fidelidade informativa e o cuidado que tinha em respeitar versões alheias. Só perde a calma (e nisto desmontanhiza-se) quando penetra em assumpto de religião. Ahi paga com rancor e ódio o ódio que os catholicos voltavam aos neoprotestantes. (LOBATO, M. 1926:VII)
}

Monteiro Lobato prefere ignorar a maneira e o porquê Léry conta a história, "porque esta só poderia interessar a algum "cacomano estudioso de cacographia comparada." De acordo com Monteiro Lobato (1926:VI), sua concepção de uma boa tradução para o texto de Léry consiste em: "cingirmo-nos fielmente ao pensamento do autor, vasando-o em linguagem coada por filtros modernos. Isso conserva na tradução o valor documental da obra, que é o que nos presta, e a torna de ingestão agradável, que é o que se quer". Monteiro Lobato, bem taxativo em sua convicção tradutória, ainda avisa aos "pixosos de archaismos cacographicos", que discordassem do seu método de tradução: que "fica-lhes o recurso de irem ás fontes - e damos a taes heróes o conselho de não esquecerem em casa o facão, a bussola de matto e o tubo de aspirina" ${ }^{73}$. Monteiro Lobato volta a afirmar que seu método de tradução é acertado, bastasse conferir a "extraordinária sahida da obra de Hans Staden ${ }^{74 " .}$

\footnotetext{
${ }^{73}$ LOBATO,M. 1926:VI

${ }^{74}$ Idem.
} 
Em relação ao método de tradução aplicado por Monteiro Lobato, Adriana S. Vieira (2004) criou a expressão teoria lobatiana da tradução, caracterizada por suas críticas à tradução literal, na qual o sentido desaparece e a obra se torna ininteligível. Segundo Monteiro Lobato, "A tradução tem de ser um transplante. O tradutor necessita compreender a fundo a obra e o autor, e reescrevê-la em português como quem ouve uma história e depois a conta com palavras suas. Ora, isto exige que o tradutor seja também escritor - e escritor decente" ${ }^{15}$.

Sobre o Colóquio $^{76}$, Monteiro Lobato o apresenta no fim do volume "para que não se interrompa o fio da narrativa"77. Para ele, este texto só possui algum valor documental (mas nem tanto), porque não foi anotado como deveria e foi deturpado nas suas sucessivas edições. Monteiro Lobato (1926:252) conserva a grafia francesa do autor para a língua indígena, e declara que não poderia ter feito de outra forma, porque ela possui muitas variações em outras anotações, e que isto era um defeito "insanável e peculiar a todas as línguas que não tinha escripta". Para a tradução do Colóquio em língua francesa, Monteiro Lobato se desvia da sua convicção de reescrita do original, e opta pela tradução literal, empregada com o propósito de conservar a irregularidade do original. Vejamos a seguir um exemplo desta tradução literal:

\section{Texto original [1880]}

T. Eori-deretani ouani repiac. Vien doncques voir le lieu où tu demeureras.

\section{Tradução M. Lobato [1926]}

T. Eori deretani ouani repiac. Vem pois ver o lugar onde você vaes morar.

Como podemos observar no exemplo acima, Monteiro Lobato realmente cumpre o que se propôs a fazer em sua anotação ao Colóquio. Ele inclusive traduz a partícula enunciativa donc do francês pela conjunção conclusiva pois do português, que não foi contemplada na tradução de Araripe. Aryon Rodrigues considera que a tradução de Monteiro Lobato possui alguns erros de execução, mas esclarece que isto se deve às falhas na edição francesa de 1880 , porque Paul Gaffarel não conseguiu identificar certas formas no manuscrito de Jean de Léry, trocando muitas vezes a letra "u" por "n" (RODRIGUES, 2013:2).

\footnotetext{
${ }^{75}$ Cf. VIEIRA, Adriana ., 2004:121.

${ }^{76}$ Título traduzido por Monteiro Lobato: Colloquio da chegada a' terra do brasil, entre um tupinambá e um francez

${ }^{77}$ Ibid.:220.
} 
Monteiro Lobato ${ }^{78}$ nasceu em 18 de abril de 1882, em Taubaté, no Estado de São Paulo, foi alfabetizado pela mãe, Olímpia Augusta, e foi Bacharel em Direito. Trabalhou como promotor no município de Areias durante três anos, mas persistiu em sua vocação literária. Monteiro Lobato fundou sua primeira editora em 1918, a Monteiro Lobato e Cia., que foi a precursora da atual Companhia Editora Nacional, fundada em 1925. Ele deu início ao movimento editorial brasileiro, que culminou no estabelecimento da impressão de livros brasileiros no Brasil, ao invés de Portugal - situação bem comum na época. Ele foi perseguido, preso $^{79}$ e criticado em 1941 porque se engajou em campanhas cívicas que pregavam o progresso do Brasil através da exploração do petróleo. Estas campanhas contrariavam o interesse oficial do governo de Getúlio Vargas, porque divulgavam as burocracias que as empresas nacionais enfrentavam ao lidar com o Conselho Nacional do Petróleo. Monteiro Lobato se consolidou como escritor de grande destaque no cenário da literatura infantil brasileira. Monteiro Lobato faleceu em 4 de julho de 1948.

Há muitas maneiras de ler. Talvez que a mais profunda seja a de quem verte um
livro para outra língua. O tradutor é um escafandrista. Mergulha na obra como num
mar, impregna-se de um pensamento concretizado de um certo modo - o estilo do
autor - e lentamente o vai moldando no barro de outro idioma, para que a obra não
admita fronteiras. Sem esses abnegados trabalhadores, a literatura ficaria adstrita a
pátrias, condenada a limites muito mais estreitos do que os permitidos pela sua
potencialidade. (LOBATO, M., 2010:237)

Com base na leitura dos prefácios e comentários das traduções de Monteiro Lobato e Alencar Araripe, estabelecemos que estas duas obras constituem um objeto de estudo pertinente ao trabalho que está sendo desenvolvido aqui, porque apesar de não proporem um tratamento à língua Tupinambá, ambos projetos de tradução serviram para nos mostrar que o propósito de traduzir a literatura estrangeira no final do século XIX e início do século XX foi essencialmente educacional: preservar e tornar acessível ao público brasileiro um conhecimento histórico sobre os primórdios dos idos coloniais; "Num paiz de mais cultura e mais amor ás suas coisas todas estas obras iniciais andariam de mão em mão e nas escolas; mas é o contrário que se dá entre nós e o Brasil maravilha entre cousas pela descuriosidade de seus filhos em conhecerem os primórdios da formação racial" (LOBATO, M.,1926: V). A este propósito, podemos afirmar que Monteiro Lobato o atingiu plenamente, dado o seu

\footnotetext{
78 Monteiro Lobato. Disponível em:< http://www.camaramonteirolobato.sp.gov.br/h/73-o-homem-querevolucionou-a-industria-editorial-no-pais-fixou-se-na-memoria-e-no-coracao-dos-brasileiros-gracas-aoconjunto-de-sua-obra-literaria-voltada-para-criancas-jovens-e-adultos>. Acesso em: 11 de out. de 2016

${ }^{79}$ A prisão de monteiro lobato. Disponível em: <http://www.oabsp.org.br/sobre-oabsp/grandes-causas/a-prisaode-monteiro-lobato>. Acesso em: 11 de out. de 2016.
} 
grande reconhecimento no universo literário infantil. Assim, concluímos que as propostas de tradução de Tristão Araripe e Monteiro Lobato estabelecem uma relação de continuidade e Crítica do ato tradutório.

\subsubsection{Plínio Ayrosa}

A terceira tradução brasileira do Colóquio foi publicada pela primeira vez em $1941^{80}$ pela editora Livraria Martins, com tradução de Sérgio Milliet, e especificamente para o Colóquio de entrada ou chegada ao Brasil, tradução e notas tupinológicas de Plínio Ayrosa. Plínio Marques da Silva Ayrosa $^{81}$ (1895-1961) nasceu em São Paulo, foi engenheiro, filósofo, professor de etnografia e especialista em dialetos Tupi e Guarani da Universidade de São Paulo, USP. Enquanto cursava a escola Politécnica, do Rio, trabalhava como repórter na Gazeta de Notícias e, nas horas vagas, dedicava-se aos estudos do Tupi e do Guarani. A convite de Sud Menucci (1892-1984), então Secretário da Educação, Ayrosa iniciou a realização, em São Paulo, de um curso de Tupi e de Guarani. Começou a lecionar em 1931, e, três anos mais tarde, tornou-se Professor Titular da Cadeira de Tupi da Universidade de São Paulo. Em 1947, já havia publicado cerca de 120 obras. Logo em seguida, com um grupo de colaboradores, construiu o Museu Indianista, um centro de estudos sobre o índio, sua língua e seus costumes.

A publicação da tradução por Milliet e Ayrosa, apresenta um grande apreço pela escrita de Léry, que pela primeira vez, não é completamente criticada. Do ponto de vista de Sérgio Milliet - que também repete o elogio de Monteiro Lobato —, Tristão Araripe traduziu Léry "muito conscienciosamente", embora com graves erros de interpretação sintática $^{82}$, "numa ortografia de sua invenção, das mais simplórias que se tem visto ${ }^{83 "}$ Milliet também critica o fato de Araripe ter julgado o estilo de Léry irregular e ter afirmado que se tratava de uma má escrita. No entanto, Milliet afirma que quem emite este julgamento não é familiarizado com a escrita do francês do século XVI, e que este era o próprio modo de ser, pensar e falar, próprio deste século:

Léry não é menos límpido que Montaigne. Lê-se de um jacto, com interesse e proveito. E se não se alça às sutilezas do autor dos Ensaios nem por isso é pesado.

\footnotetext{
${ }^{80}$ Cf. Referências Bibliográficas: LÉRY, Jean. Viagem à terra do Brasil, 2007.

${ }^{81}$ Plínio Ayrosa. Disponível em: 〈http://www.fflch.usp.br/dl/documenta/fichas descritivas/Ayrosa 1934.htm>. Acesso em: 19 jun. 2016.

${ }^{82}$ Assim como vimos no exemplo do diálogo.

${ }^{83}$ LÉRY, Jean. Op cit., 2007:13.
} 
Ao contrário, sua frase, longa como a de todos os escritores de seu tempo, inclusive os portugueses, não deixa de ter uma construção harmônica, precisa, dentro da qual o pensamento matizado se abriga à vontade. [...] Léry escreve como outros pintam ou tocam música, sem nunca ter aprendido; com uma naturalidade de causar inveja aos mais sábios autores e aos mais espertos estilistas. Escreve bem sem esforço e diz o que deseja como quer. (LÉRY, 2007:17)

Entretanto, Milliet (2007:18) não deixa de fazer suas considerações sobre o texto de Léry ao comentar que "muitos latinismos estorvam a limpidez da expressão, mas o simples conhecimento do português, do italiano e do espanhol os esclarecem". Ele alerta também para o fato de que muitas palavras adquiriram novo sentido devido à evolução da língua, que contribuiu com muitos empréstimos de vocábulos, por exemplo: "aimable não corresponde ao nosso amável, mas sim a digno de ser amado" (LÉRY, 2007:18). Aryon Rodrigues considera que, até então, a edição de Sérgio Milliet e Plínio Ayrosa havia apresentado a melhor tradução portuguesa da obra de Léry (RODRIGUES, 2009:47).

Sérgio Milliet, em introdução à obra de Jean Léry, faz grandes elogios ao trabalho de Plínio Ayrosa, que pela "primeira vez, conseguiu interpretar e reestabelecer o texto tupi do diálogo do Colóquio", seguido de observações gramaticais. Por isso, Sérgio Milliet defende Ayrosa das duras críticas que recebeu sobre esta restauração do Colóquio, que foi considerada "absurda e confusa" (MILLIET, 2007:14). Ayrosa (2007:17), obviamente discorda, e defende que seu trabalho é "de enorme interesse, inclusive no que diz respeito a certas formas arcaicas da língua".

Parte integrante do trabalho de Léry, o Colóquio não podia deixar de sofrer deturpações e de eivar - se de erros tipográficos à medida das reedições e traduções da obra. Editores e tradutores, não conhecendo a língua em que parcialmente fora escrito, aos lapsos e erros inevitáveis dos originais sobrepuseram erros e lapsos novos. E de tal forma que, hoje, os próprios conhecedores da língua tupi-guarani dificilmente conseguem interpretar o texto, sobremodo interessante. (AYROSA, 2007:271)

Ayrosa propôs restaurar, traduzir e fazer anotações sobre o texto de Léry, "no sentido de manter as restaurações tão próximas quanto possível do texto e, mais, fugir das interpretações dadas em francês pelo autor" (2007:272).

\footnotetext{
As nossas anotações, dado o caráter desta publicação, não passam de simples sugestões a respeito deste ou daquele termo, desta ou daquela referência de Léry. [...] Limitamo - nos agora a dar ao leitor, tão sinteticamente quanto possível, os informes de caráter linguístico que justifiquem as nossas restaurações e interpretações. (AYROSA, 2007:273)
}

No entanto, Rodrigues (2009:46) aponta que Ayrosa se confundiu, ao introduzir formas do Guarani na restauração do texto em Tupinambá original, e por ter suposto formas 
que não existem nesta língua, "baseado na escrita deficiente de Léry". Nesta tradução do Colóquio realizada por Ayrosa, apenas a língua Tupinambá restaurada e sua respectiva tradução para o português foram apresentadas. O texto original em francês, bem como a língua Tupinambá no original de Léry, foram suprimidos desta edição, com exceção das anotações de Léry, que complementam o sentido dos diálogos, ao descrevê-los a partir dos únicos referenciais que conhece, oriundos da sua visão de mundo. Vejamos a seguir um exemplo desta operação tradutória:

\title{
Tradução Ayrosa [2007]
}

(54) Makakuá Macaguá (é uma espécie de perdiz grande, de corpo maior que o de um capão)

A partir do exemplo acima, observamos que o texto restaurado e traduzido do Colóquio é bem sintetizado e esta característica se alinha à crítica de Ayrosa sobre "a interpolação de frases e palavras evidentemente descabidas num simples diálogo de entrada. Longa série de frases, por exemplo, põe Léry na boca do seu interlocutor tupinambá, como se o índio fosse um catequista tocado pela mania de filosofar antes de viver" (LÉRY, 2007:272). Neste sentido, Ayrosa esclarece que,

\begin{abstract}
A nossa tentativa, evidentemente ousada, de dar em português o que realmente está escrito em língua brasílica, e não o que tem sido dado por intermédio da interpretação mais ou menos vaga do próprio Léry, funda-se em três elementos essenciais: no texto tupi de uma edição latina da "viagem", muito melhor grafado que o da edição de Gaffarel e outras; no estudo de Batista Caetano, que cuidadosamente tentou restaurar as frases e expressões do Colóquio, sem as verter, contudo, para o português, e na série valiosa de vocabulários tupi costeiro, atualmente de fácil consulta. (LÉRY, 2007:271)
\end{abstract}

Esta opção editorial — da não inclusão do texto em língua Tupinambá original de Léry e sua tradução do francês para o português — constitui uma grande perda, do ponto de vista de Aryon Rodrigues, no sentido de que o valor documental para o Colóquio foi reduzido e substituído por um texto descaracterizado devido a uma restauração linguística que utilizou como base as formas de uma língua que não era a apropriada (língua Guarani). É importante destacarmos que, como tradutor e linguista, Ayrosa recorreu à tradução de Batista Caetano para obter informações sobre a tradução da língua Tupinambá. Por isso, é plausível que Ayrosa tenha repetido algumas falhas, cometidas por Batista Caetano, na tradução das formas de Tupinambá por Guarani. Porém, Ayrosa pondera também que Batista Caetano tentou reduzir as frases e palavras de Léry, e que este era o fator negativo no excelente trabalho de 
Batista Caetano. Ayrosa também menciona que traduziu o Colóquio a partir de uma edição latina $^{84}$, sem especificar de qual se trata, mas acreditamos que deva ser a mesma utilizada por Batista Caetano, da qual também não temos informação sobre o número da edição.

Plínio Ayrosa (2007:273) reconhece que ainda há muito trabalho a ser feito referente à restauração da língua Tupinambá: "Sendo esta a primeira tentativa que faz de transladar para o português o texto integral de Léry, [...] é de esperar-se apresente inúmeras falhas e senões; senões e falhas, entretanto, que os competentes corrigirão e sanarão para maior prestígio e valorização deste delicioso Colóquio". E, por isso deixa um convite de continuidade à tradução:

Nem sempre conseguimos vencer, entretanto, mesmo com o auxílio indispensável de Batista Caetano, uns tantos passos por demais ásperos do texto. Muito há, por isso a respigar nesse documento, mas o que aí fica servirá, ao menos, de sugestões aos que melhor possam se desobrigar de tão ingrata quão tentadora tarefa (AYROSA, 2007:272).

O fato de Ayrosa assumir o posicionamento de que sua tradução não é definitiva e terminada é muito importante, porque assim podemos inferir que ele, enquanto linguista, realizou uma tradução consciente, e que reconhece que existe uma limitação de conhecimento e material de estudo sobre a língua indígena, que não o permitiu avançar mais, acreditando, contudo, que futuramente esta questão poderá ser contemplada por outro estudioso. Outros tradutores do Colóquio apresentaram este mesmo posicionamento realista e consciente de que não se pode conhecer ou resolver tudo. Alguns foram sutis, outros nem tanto, como Monteiro Lobato, que demonstra estar muito convicto do seu método e avalia sua aplicabilidade pelo número de vendas que sua tradução alcança.

A propósito deste posicionamento de produzir uma tradução última e definitiva, discutimos no início deste capítulo o conceito de continuum de conversões de W. Benjamin, e o modo como este influencia a retradução. Normalmente, quando trabalhamos um continuum de conversões nos referimos a várias versões de um mesmo texto produzidas por um mesmo tradutor. Porém, nesta pesquisa o continuum de conversões foi trabalhado a partir de uma edição das diferentes traduções do Colóquio publicadas no Brasil em 1876, 1889, 1926, 2007 e 2009, respectivamente por Batista Caetano, Tristão Araripe, Monteiro Lobato, Plínio Ayrosa e Aryon Rodrigues. O conceito de continuum de conversões abordado em Benjamin, foi aqui redirecionado para discutir as retraduções. Esta abordagem só foi possível na medida em que

\footnotetext{
${ }^{84}$ A edição latina mais citada nesta edição de 2007 é a da famosa coleção dos Granas et petits voyages, de Teodoro de Bry. Francfort, 1592 - $3^{\circ}$ vol. Mas não há como saber, com certeza, se esta é a edição que Ayrosa utiliza para a sua tradução.
} 
cada tradutor estabeleceu um locus para que sua pesquisa/tradução recebesse uma continuação, uma nova proposta para corrigir possíveis falhas, ou a proposta de um novo método. Este posicionamento é muito incomum referente às traduções publicadas, porque tradutores não costumam se colocar em uma posição tão vulnerável, permitindo uma Crítica aos seus trabalhos. Os tradutores, ao admitirem que seus trabalhos atingiram certo limite, nos proporcionaram material para que pudéssemos elaborar hipóteses mais concretas sobre o resultado das operações tradutórias, discutir em que ponto atingiram o projeto de tradução previamente estipulado e revelar o que não foi concluído, estabelecendo um locus para a discussão de outras retraduções.

A propósito da análise das traduções brasileiras aqui apresentadas, elaboramos uma tabela que resume, essencialmente, os traços fundamentais que foram identificados para realizarmos uma Crítica destas traduções. Vejamos na tabela a seguir o cumprimento dos critérios estipulados por Berman para a realização da Crítica:

Tabela 4- Levantamento dos traços fundamentais das traduções visando a Crítica

\begin{tabular}{|c|c|c|c|c|c|}
\hline & $\begin{array}{c}\text { Sujeito } \\
\text { tradutor }\end{array}$ & Posição tradutória & \multicolumn{2}{|c|}{ Projeto de tradução } & \multicolumn{2}{|c|}{$\begin{array}{c}\text { Horizonte } \\
\text { tradutivo }\end{array}$} \\
\hline $\begin{array}{c}\text { Batista Caetano } \\
(\mathbf{1 8 7 6 )}\end{array}$ & Filólogo & $\begin{array}{c}\text { "O Diálogo de Léry" - } \\
\text { Nota preliminar e notas } \\
\text { de fim }\end{array}$ & $\begin{array}{c}\text { Não se } \\
\text { aplica }\end{array}$ & Restaurar & Língua Guarani \\
\hline $\begin{array}{c}\text { Tristão Araripe } \\
(\mathbf{1 8 8 9})\end{array}$ & Magistrado & Advertência e notas & \multicolumn{2}{|c|}{ Tradução livre } & $\begin{array}{c}\text { Grafia } \\
\text { particular/Tradução } \\
\text { onomástica }\end{array}$ \\
\hline $\begin{array}{c}\text { Monteiro Lobato } \\
\text { (1926) }\end{array}$ & Escritor & Prefácio e notas & $\begin{array}{c}\text { Tradução } \\
\text { livre }\end{array}$ & $\begin{array}{c}\text { Tradução } \\
\text { literal }\end{array}$ & $\begin{array}{c}\text { Traduzir e recriar } \\
\text { (nacionalista) }\end{array}$ \\
\hline $\begin{array}{c}\text { Plínio Ayrosa } \\
(\mathbf{1 9 4 1})\end{array}$ & Filólogo & $\begin{array}{c}\text { Nota Prévia e notas de } \\
\text { fim }\end{array}$ & $\begin{array}{c}\text { Restaurar e Traduzir } \\
\text { (científico) }\end{array}$ & Língua Guarani \\
\hline $\begin{array}{c}\text { Aryon Rodrigues } \\
\text { (2009) }\end{array}$ & Linguista & $\begin{array}{c}\text { "As contribuições } \\
\text { linguísticas de Jean de } \\
\text { Léry" - Prefácio }\end{array}$ & $\begin{array}{c}\text { Restaurar e Retraduzir } \\
\text { (científico) }\end{array}$ & $\begin{array}{c}\text { Língua Tupinambá: } \\
\text { grafia jesuítica }\end{array}$ \\
\hline
\end{tabular}

Fonte: CESAR, Janaína T. G., 2016

A partir da tabela acima, verificamos a presença dos três modos de tradução admitidos por Berman e Gambier: "o primeiro, palavra por palavra; o segundo, onde assume um caráter livre e adapta o original à cultura do tradutor; e o terceiro, que reproduz as singularidades culturais, linguísticas do original" (MATTOS, 2014:43). Na tradução palavra por palavra, podemos citar a tradução de Monteiro Lobato para o Colóquio, onde ele reproduziu os diálogos na mesma ordem em que aparecem no original de 1880, e os traduziu usando "equivalentes" na língua portuguesa. A tradução livre pode ser vista no projeto de Tristão Araripe para toda a obra de Léry, como também no projeto de tradução de Monteiro Lobato, 
para os outros capítulos, com exceção do Colóquio. A tradução que reproduz as singularidades não chegou a atingir uma completude nos projetos de Batista Caetano e de Plínio Ayrosa, porque alguns de seus referenciais sobre a língua falada no Colóquio estavam equivocados.

A partir desta classificação de projetos de tradução, entendemos porque Aryon Rodrigues não contempla as traduções propostas por Tristão Araripe e Monteiro Lobato em seu prefácio à edição de 2009 do Colóquio entres as gentes do país: a análise destas traduções não resultaria em uma crítica produtiva, porque não compartilham do mesmo projeto de Aryon Rodrigues. No entanto, convém mencionarmos alguns pontos nos quais as publicações brasileiras se aproximam, por exemplo: a crítica à escrita de Jean de Léry, o uso da edição de 1880 anotada por Paul Gaffarel, o uso da edição latina, a apreciação ao valor histórico da obra de Léry, etc. A partir da análise dos traços fundamentais percebemos também que Batista Caetano, Tristão Araripe e Monteiro lobato não questionam a autoria de Jean de Léry para o Colóquio, isto provavelmente ocorreu porque são anteriores à discussão deste tema entre etnógrafos e linguistas, na proporção que adquiriu ${ }^{85}$; como vimos no capítulo anterior, este foi um questionamento presente nos prefácios de Aryon Rodrigues e Plínio Ayrosa, porque esta discussão ainda é debatida e gera, ainda, várias hipóteses, inclusive, no trabalho desenvolvido por nós no primeiro capítulo.

\subsection{POR QUE RETRADUZIR?}

Para concluirmos o estudo comparado dos projetos de tradução do Colóquio, desenvolvemos uma tabela que sintetiza o horizonte tradutivo destas traduções, por meio de um novo trabalho de Yves Gambier ${ }^{86}$, no qual ele trata das razões pelas quais retraduzimos (MATTOS, 2014:49). Dentre as razões mencionadas em Gambier (2012), três são particularmente interessantes para os projetos de tradução do Colóquio. Vejamos na tabela a seguir, qual a aplicabilidade destas razões às traduções brasileiras do Colóquio:

\footnotetext{
${ }^{85}$ Cf. LESTRINGANT, Frank. Le Huguenote et le sauvage, 2004.

${ }^{86}$ Cf. GAMBIER, 2012.
} 
Tabela 5 - Razões para retraduzirmos (Gambier, 2012)

\begin{tabular}{|c|c|c|c|}
\hline & $\begin{array}{c}\text { Restituir e recuperar aspectos } \\
\text { fundamentais (linguísticos, } \\
\text { textuais, estilísticos, etc. })\end{array}$ & $\begin{array}{c}\text { Traduzir } \\
\text { diretamente do } \\
\text { original }\end{array}$ & $\begin{array}{c}\text { Ter uma leitura do texto não } \\
\text { contemplada nas traduções } \\
\text { anteriores }\end{array}$ \\
\hline $\begin{array}{c}\text { Batista Caetano } \\
\mathbf{1 8 7 6}\end{array}$ & Sim & Não & Não se aplica \\
\hline $\begin{array}{c}\text { Tristão Araripe } \\
\mathbf{1 8 8 9}\end{array}$ & Sim & Não & Não \\
\hline $\begin{array}{c}\text { Monteiro Lobato } \\
\mathbf{1 9 2 6}\end{array}$ & Não & Não & Sim \\
\hline $\begin{array}{c}\text { Plínio Ayrosa } \\
\mathbf{1 9 4 1}\end{array}$ & Sim & Sim & Sim \\
\hline $\begin{array}{c}\text { Aryon Rodrigues } \\
\mathbf{2 0 0 9}\end{array}$ & Sim & Sim & Sim \\
\hline
\end{tabular}

Fonte: CESAR, Janaína T. G., 2016

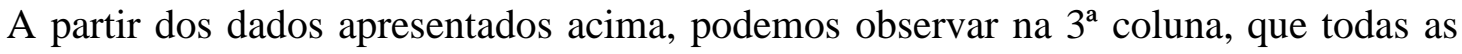
traduções estabelecem uma nova leitura em relação à tradução anterior, com exceção de Batista Caetano que não traduz para o português. Isto ocorre porque estas traduções partem de textos originais diferentes: ora uma edição francesa de 1580, 1611 e 1880, ora uma edição latina, e nós sabemos que todas as edições sofreram sucessivas modificações na editoração. Outro fato importante refletido nesta tabela, é que as traduções de Plínio Ayrosa e Aryon Rodrigues inserem uma quebra de paradigma no que se refere à escolha de traduzir diretamente do original (coluna 2), que é a língua Tupinambá do século XVI. Por último, o destaque de Monteiro Lobato como a única oposição à respeito da restituição de aspectos fundamentais da obra (coluna 1). Isto claramente reflete suas convicções de adaptação e reescritura do original a partir da tradução, que foram enunciados em seu prefácio à obra de Léry.

A partir destas conclusões, retomamos o pensamento de Berman (1990:1) de que "as primeiras traduções não podem ser as maiores "porque dependendo do que traduzimos se não houver um distanciamento, não conseguimos entender completamente a dimensão do original, e poderemos não dispor de bons recursos, tecnológicos ou não, para realizar uma "grande tradução". Esta afirmação de Berman possui aplicabilidade direta na análise da sucessão das traduções brasileiras do Colóquio. Em 1876, quando Batista Caetano realizou a tentativa de restauração da língua indígena, o dicionário Tupinambá dos jesuítas (Vocabulário na Língua Brasílica - 1938) ainda não havia sido publicado. Portanto, não pôde identificar as diversas formas da língua Tupinambá, e acabou confundido-a com a língua dos Guaranis. As tentativas de restauração seguintes, de Plínio Ayrosa (1941) e Aryon Rodrigues (2009), já obtiveram algum êxito, porque se encontravam em uma posição cientificamente mais avançada para o 
estudo das línguas indígenas. Estas razões constituem o início da hipótese de nosso trabalho que leva em conta a Crítica realizada por Aryon Rodrigues em seu prefácio intitulado: As Contribuições linguísticas de Jean de Léry ${ }^{87}$ à restauração de Batista Caetano (1876), e à restauração e tradução de Plínio Ayrosa (1941) da língua Tupinambá do século XVI.

A partir da análise comparativa entre os projetos de tradução do Colóquio, desenvolvemos a hipótese de que a retradução é o locus da Crítica produtiva e positiva. Esta hipótese nos leva ao objeto de estudo principal desta pesquisa: demonstrar que o projeto de restauração e tradução de Aryon Rodrigues para o Colóquio entre as gentes do país não se sustenta apenas em oferecer uma tradução mais atual para a língua francesa e a Tupinambá. Ele se diferencia, principalmente, nos métodos que aplica para construir o conhecimento de uma língua indígena que não possui mais falantes e tem raras documentações sobre sua estrutura linguística. Este método é a restauração da língua Tupinambá a partir do estudo descritivo da língua, e do método de tradução, como um complemento para restaurar formas que não são identificáveis na escrita do Colóquio, pois o método de tradução permite acessar um conhecimento do funcionamento e estrutura da língua.

Abordaremos o projeto etnolinguístico de Aryon Rodrigues, separadamente, no capítulo seguinte, onde trataremos o seu posicionamento enquanto um pesquisador de línguas indígenas que busca expandir o conhecimento linguístico da língua Tupinambá falada no século XVI. Este projeto é compreendido a partir de um objetivo de preservação desta documentação por meio de operações plurilíngues, que colocam em evidência os métodos utilizados por Rodrigues para enriquecer os estudos sobre esta língua, e estabelecer um campo de pesquisa, que ainda precisa de muitos recursos e linguistas interessados, para solidificar o estudo das línguas indígenas como objeto essencial à investigação da linguagem humana. Assim como nas traduções analisadas neste capítulo, abordaremos o sujeito tradutor, a posição tradutória, o projeto de tradução e o horizonte tradutivo, a partir do prefácio redigido por Aryon Rodrigues, intitulado: Contribuições linguísticas de Jean de Léry, que é um material de pesquisa fundamental para compreendermos a função da tradução no seu projeto etnolinguístico.

\footnotetext{
${ }^{87}$ Cf. RODRIGUES, A.D., 2009.
} 


\section{CAPÍTULO 3}

\section{AS OPERAÇÕES PLURILÍNGUES DE ARYON RODRIGUES PARA UM CONHECIMENTO LINGUÍSTICO}

Toda teoria linguística e os métodos de trabalho do linguista repousa, necessariamente, sobre a experiência que se vai adquirindo com as línguas e, como estas soam diferentes, a experiência será mais completa, quanto maior for o número de línguas conhecidas. 


\subsection{OS ESTUDOS LINGUÍSTICOS DE ARYON RODRIGUES}

Aryon Dall'Igna Rodrigues ${ }^{88}$, especialista em línguas indígenas e com uma produção ininterrupta na área por quase sete décadas, foi um grande linguista no que diz respeito à classificação e à construção do conhecimento linguístico das línguas indígenas no território brasileiro. Atuou no campo das línguas indo-europeias, africanas e, principalmente, das línguas indígenas sul-americanas. Foi professor na UFPR, UFRJ e UNICAMP e professor visitante nas universidades Cornell, Califórnia/Berkeley, México, Münster, Montevidéu, UFRGS, USP, UFMG, UFBA, UFSC e UFPA. Foi membro fundador e primeiro presidente da Associação Brasileira de Linguística (ABRALIN), membro da Associação Brasileira de Antropologia (ABA), membro honorário da Linguistic Society of America (LSA), da Society for the Study of the Indigenous Languages of the Americas (SSILA) e da Société des Américanistes de Paris.

Sua trajetória acadêmica teve início em 1950 quando se graduou em Letras Clássicas pela Universidade Federal do Paraná (UFPR). Em 1959, adquiriu o título de doutor em linguística pela Universidade de Hamburgo, na Alemanha (Dr. Phil., Universität Hamburg). De volta ao Brasil em 1960, ele foi professor de linguística e de etnografia do Brasil na UFPR. Em 1962, Aryon Rodrigues foi convidado pelo antropólogo Darcy Ribeiro para ser consultor do Instituto de Letras da UnB, cuja criação era estudada sob a coordenação do escritor Ciro dos Anjos. No ano seguinte, após encerrar as obrigações com a UFPR, tornou-se professor efetivo da UnB. Quatorze meses após sua chegada à UnB, ocorreu o golpe militar de 1964. Em função das duras ações da ditadura militar, Aryon Rodrigues, conjuntamente a mais de duzentos professores da UnB, decidiu se demitir. Em um só dia foram protocolados 225 pedidos de demissão na Reitoria. Aryon Rodrigues então seguiu para o Uruguai, onde participou de cursos no Programa Interamericano de Linguística. Depois deste episódio, Rodrigues retornou ao Brasil e teve atuação em várias universidades brasileiras. Ele criou e coordenou os programas de pós-graduação em linguística na UnB (1963-65), no Museu Nacional/UFRJ (1968-1972) e na UNICAMP (1974-1976).

Em 1988, Aryon Rodrigues voltou à UnB como professor do Departamento de Linguística, Português e Línguas Clássicas (LIP). Em 1996, ganhou o título de professor

\footnotetext{
${ }^{88}$ Cf. ULHOA, Marcela. Aryon Rodrigues. Existem mais de 200 línguas e só se ensina português. Correio Braziliense, Brasília, Dez. 2012. Disponível em: 〈http://goo.gl/9XKLiC〉. Acesso em: 02 abr. 2016.
} 
emérito pela Universidade de Brasília. Três anos depois, criou e coordenou o Laboratório de Línguas Indígenas (LALI) da UnB. Aryon Rodrigues também foi um dos criadores da Revista Brasileira de Linguística Antropológica. Em 2012, recebeu a maior honraria acadêmica da UnB: o título de doutor Honoris Causa. Rodrigues também foi Professor Honoris Causa pela Universidade Federal do Paraná (2009), Pesquisador em Produtividade Científica do CNPq e Pesquisador Associado do Instituto de Letras da UnB. Em janeiro de 2013, participou da criação do Instituto Aryon Dall'Igna Rodrigues (IADR), que passou a ser a instituição responsável pelo inestimável acervo documental e bibliográfico reunido pelo pesquisador ao longo de sua carreira acadêmica. Aryon Rodrigues faleceu no dia 24 de abril de 2014.

Falando fluentemente e traduzindo de diversas línguas, Aryon Rodrigues concentrou boa parte de sua carreira acadêmica no estudo de línguas indígenas e, foi através desta competência linguística, que ele se tornou apto a tarefa de traduzir e restaurar os diálogos em língua francesa e em Tupinambá original do século XVI para a língua portuguesa no Colóquio entre as gentes do país de Jean de Léry, contribuindo para um resgate histórico e linguístico da língua Tupinambá. Este, portanto, torna-se o trabalho mais notável e acessível de Aryon Rodrigues no que diz respeito à discussão da relação entre estas três línguas.

Após esta breve apresentação do percurso acadêmico de Aryon Rodrigues, pretendemos destacar neste capítulo como a sua formação na Linguística orienta o seu trabalho de descrição e restauração das línguas indígenas no Brasil. A investigação das línguas indígenas contribui para o incremento do conhecimento linguístico sobre outras formas de comunicação humana (RODRIGUES, 1966:4). À nível de conhecimento humano, Rodrigues (1986:27) afirma que "cada língua indígena brasileira não só reflete, assim, aspectos importantes da visão de mundo desenvolvida pelo povo que a fala, mas constitui, além disso, a única porta de acesso ao conhecimento pleno dessa visão de mundo que só nela é expressa". Quando uma língua se extingue, se extingue com ela todo um acúmulo de conhecimento sobre a experiência e uma percepção particular de visão de mundo. Em relação ao nível de conhecimento linguístico, a situação da documentação de línguas indígenas brasileiras é crítica, há pouco interesse em documentar as línguas indígenas in loco, e estas línguas estão se extinguindo cada vez mais depressa. De acordo com Rodrigues (1966:5), a investigação leva à descoberta de novas estruturas, que podem anular conceitos firmados anteriormente e abrir novos horizontes para a visualização geral do fenômeno da linguagem humana. 
Ao relacionarmos os estudos das línguas indígenas ao conhecimento humano e linguístico, precisamos ter uma concepção sólida do que entendemos por língua. Neste sentido nos aproximamos dos estudos de Mattoso Câmara $(1977)^{89}$, ao concebermos que a língua antes de tudo, é forma, e através da sua configuração formal ela integra e multiplica os elementos culturais. A língua se torna portadora de um dado cultural, é a representação "em miniatura de toda a cultura" (CÂMARA, 1977:18). Isto justifica o estudo da língua no âmbito de uma pesquisa etnográfica. A Linguística também admite que a língua apresenta uma configuração formal de caráter representativo, que vive por si - independente de sua ligação à cultura. Este também é o caso das línguas indígenas. Elas possuem, antes de tudo, uma configuração formal, um sistema, uma estrutura que se estabelece para a comunicação através da fala ${ }^{90}$.

De acordo com o linguista dinamarquês Louis Hjelmslev (1969) ${ }^{91}$, o caráter representativo de uma língua só aparece quando sua "expressão" (exteriorização fônica) passa a significar alguma coisa; este significar é o que Hjelmslev denomina "conteúdo" (valor que a expressão tem dentro da língua). A soma destes dois elementos resulta na forma linguística. Este é um desdobramento da teoria do signo linguístico proposta por Ferdinand de Saussure no Curso de Linguística Geral $^{92}$, onde o significante é representado pela "expressão" e o significado pelo "conteúdo" em Hjelmslev.

Para realizar a investigação de uma língua indígena e estabelecer um novo conhecimento sobre ela, Aryon Rodrigues se baseia no estudo sincrônico das línguas (termo originado do grego syn- "reunião", chrónos "tempo"). Este estudo é de natureza descritiva e tem por objetivo analisar as línguas indígenas a partir de uma perspectiva estática do seu estado linguístico (CÂMARA, 1989:40), ou seja, as línguas tal como são faladas ou escritas são estudadas da forma como se apresentam em um determinado momento da sua história. Esta é a abordagem utilizada por Rodrigues para restaurar a língua Tupinambá reproduzida por Léry em 1580, que discutiremos logo mais neste capítulo.

A descrição da língua Tupinambá que apresentaremos neste trabalho será abordada apenas no plano morfológico da língua, portanto, nos deteremos ao estudo das formas da

\footnotetext{
${ }^{89}$ Cf. CÂMARA Jr., J. Mattoso. Introdução às Línguas Indígenas Brasileiras. 3. ed. Rio de Janeiro: Ao Livro Técnico, 1977.

${ }^{90}$ Ibid.:25.

${ }^{91}$ Cf. HJELMSLEV, Louis. Prologomena to a theory of language. Translated by Francis J. Whitfield. Madison: University of Winsconsin Press, 1969.

${ }^{92}$ Cf. SAUSSURE, Ferdinand de. Curso de Linguística Geral. São Paulo: Cultrix, 2006.
} 
língua Tupinambá. Esta limitação na abordagem é feita com o objetivo de focar nas formas mínimas que se inserem no estudo da significação.

De acordo com Câmara (1977:49), "só chegamos ao âmago formal de uma língua com a dedução da forma mínima, isto é, de um segmento fônico com determinada significação e indivisível na sua qualidade de expressão ligada a um conteúdo". As formas mínimas se agrupam em vocábulos, que por sua vez, se agrupam em frases; podendo ser divididas entre semantemas e morfemas. Os semantemas são as "formas mínimas básicas, que servem à língua para ela se reportar ao universo cultural do falante; [...] os morfemas são os elementos gramaticais da língua, por meio dos quais ela se estrutura como forma” (CÂMARA, 1977:53). Uma situação bem comum na estrutura formal da língua Tupinambá é a existência da alomorfia: quando a forma varia de substância fônica, mas o conteúdo nocional permanece o mesmo $^{93}$. Este fator causa grande dificuldade na identificação dos morfemas para quem não possui um conhecimento gramatical aprofundado da língua em questão, podendo confundi-la com uma nova forma.

Para se estabelecer uma análise essencialmente sincrônica da língua Tupinambá reproduzida em 1580, Aryon Rodrigues precisou depreender os morfemas que constituem as enunciações dos diálogos do Colóquio de Jean de Léry, da forma como se apresentam na língua no momento e com seus valores atuais. Estes morfemas são divididos por Rodrigues (2010) em raízes e afixos, formados por quatro elementos: o marcador de sujeito, marcador de objeto, a raiz e o marcador de negação verbal. A linguística sincrônica, de acordo com Mattoso Câmara (1989:41), estabelece que a raiz, por ser um elemento fixo, se torna o núcleo de um vocábulo, assim, nela está inscrito o estado linguístico da língua, que, consequentemente, não é afetado por estados linguísticos anteriores. Isto significa que a raiz é o ponto referencial para dar início à análise do estado da língua Tupinambá. Do ponto de vista de Rodrigues (1986:24), "uma forma verbal do Tupinambá pode ser bastante complexa, mas não mais que uma forma do Português". Para exemplificar como se dá este estudo descritivo da língua Tupinambá, Rodrigues introduz o exemplo de $(n a)$ pesepiáki: "vocês não o viram", que é formado por quatro elementos: pe-, marcador de sujeito ("vocês"); s-, marcador de objeto ("o"); -epiák, raiz ("ver"); -i, marcador de negação verbal (que se usa redundantemente com a partícula negativa $n a$, que precede o verbo).

De posse destes referenciais elementares para a análise da estrutura formal da língua Tupinambá, discutiremos no ponto a seguir como estes conhecimentos se inserem em um

\footnotetext{
${ }^{93}$ Ibid.: 57.
} 
projeto de restauração da língua Tupinambá reproduzida em 1580 por Jean de Léry no Colóquio entre as gentes do país.

\subsection{O PROJETO ETNOLINGUÍSTICO DE RESTAURAÇÃO DA LÍNGUA BRASÍLICA}

No prefácio redigido especificamente para o Colóquio, intitulado: A contribuição linguística de Jean de Léry, Aryon Rodrigues (2009:47) manifesta seu interesse na "preservação da reprodução do Colóquio como documento linguístico e histórico". Para atingir este objetivo, ele propõe reproduzir o texto indígena exatamente como apareceu na edição de $1580^{94}$ e propõe uma tradução literal da versão francesa de Léry para o português atual. Rodrigues ressalta que estes dois elementos foram igualmente suprimidos da tradução do Colóquio realizada por Plínio Ayrosa, que optou apenas em fornecer a restauração do texto em Tupinambá e sua tradução direta para o português, comprometendo assim, o valor documental deste Colóquio, que consiste justamente na reprodução do texto em língua indígena e sua respectiva tradução para a língua francesa.

Com o intuito de preservar o valor documental do Colóquio para a Linguística e a História, Rodrigues apresenta uma nova proposta de reconstituição da língua Tupinambá reproduzida na edição de 1580 . Esta reconstituição aponta para a restauração da forma e o conteúdo da língua Tupinambá, que, como vimos no segundo capítulo onde discutimos a Crítica das retraduções anteriores a de Rodrigues, não teve o tratamento linguístico adequado no trabalho de Ayrosa por restaurá-la utilizando a estrutura da língua Guarani. A reconstrução é operada através das formas da língua Tupinambá encontradas, principalmente, em fontes portuguesas do século XVI e XVII, obras de missionários jesuítas (RODRIGUES, 2009:44). Este trabalho de reconstituição da língua Tupinambá a ser operado por Rodrigues se torna o objeto de estudo principal desta pesquisa, porque revela um projeto científico para o Colóquio, que não se resume apenas a uma operação tradutória de um texto clássico do século XVI, mas uma construção de conhecimento sobre uma língua extinta, cujos falantes foram dizimados por um "processo colonizador extremamente violento e continuado" (RODRIGUES, 2005:36) no território brasileiro, comandado pelos conquistadores portugueses.

É importante salientarmos que Rodrigues ao optar pelo termo "reconstituir" para se referir ao novo projeto para a língua Tupinambá de 1580, utiliza o termo oriundo da

\footnotetext{
${ }^{94}$ A edição de 1580 é a $2^{\text {a }}$ edição de História de uma viagem feita à terra do Brasil. Ela foi revista, corrigida e acrescida de figuras e comentários pelo próprio autor.
} 
Linguística associado às línguas indígenas (ou outras línguas) que não possuem mais falantes e, que dependem de documentações linguísticas e etnográficas - muitas vezes escassas - para serem restauradas; ao contrário do termo "revitalizar", que é o termo aplicado apenas a línguas indígenas que ainda possuem falantes, mas que estão em situação de extinção ou ameaçadas. O que nos interessa discutir neste trabalho é o modo como se deu esta restauração da forma e do conteúdo da língua Tupinambá reproduzida no texto de Léry (1580), analisando-o em um contexto que denominamos "operações plurilíngues" realizadas por Aryon Rodrigues, que compõem o que caracterizamos como sendo seu projeto etnolinguístico para o Colóquio. Neste sentido, cabe aqui explicarmos o que entendemos por projeto etnolinguístico e por que o conjunto de operações plurilíngues de Rodrigues o representa; de acordo com Dubois (2002:186) a etnolinguística "é o estudo da língua enquanto expressão de uma cultura e em relação com a situação de comunicação [...], aplicada essencialmente às sociedades primitivas", ela aborda as problemáticas que se referem às relações entre língua e visão de mundo, que acabam por revelar determinadas formas de organizar o mundo, estas problemáticas também envolvem a questão da comunicação entre povos de línguas diferentes. O objetivo de colher através da língua dados etnológicos, coloca também a língua sob a égide de outros interesses que não os linguísticos, mas é um meio de se chegar ao mundo extralinguístico que o indígena criou e onde funciona a língua nativa (CÂMARA, 1977:125)

Rodrigues (2005:36) aponta que "para documentar adequadamente a língua de um povo culturalmente tão diferente quanto os índios, o linguista precisa de uma percepção etnológica, razão por que sua pesquisa é também denominada etnolinguística". De fato, como demonstraremos no ponto a seguir, a proposta de restauração da língua Tupinambá realizada por Rodrigues está calcada no saber etnolinguístico, porque trabalhamos com a hipótese principal de que este projeto científico não tem o propósito de diminuir as contribuições dos linguistas anteriores a ele que se propuseram a esta tarefa, mas de somar conhecimento sobre a língua Tupinambá a este clássico da literatura francesa de viagem, democratizando este conhecimento ao disponibilizar uma leitura mais acessível, de fácil reconhecimento, da língua indígena ao leitor de língua portuguesa.

\subsection{OPERAÇÕES PLURILÍNGUES DE ARYON RODRIGUES}

A análise que trataremos neste trabalho sobre as operações plurilíngues do Colóquio de Jean de Léry, orquestradas por Aryon Rodrigues, é discutida a partir da presença de três 
línguas: o Tupinambá original e restaurado, o francês do século XVI e o português atual. Sabemos que o Colóquio tratado por Rodrigues na edição de 2009 não contém a reprodução do texto em francês do século XVI, haja vista que sua tradução é destinada ao público brasileiro, leitor de língua portuguesa; porém, o projeto de restauração e tradução de Rodrigues contém: a língua Tupinambá original - tal como é reproduzida na edição de 1580, a língua Tupinambá restaurada a partir da grafia jesuítica do século XVII, a tradução literal do francês do século XVI e a tradução literal a partir do Tupinambá restaurado. Para tornar este trabalho analítico das operações plurilíngues mais completo, optamos por incluir nos exemplos de diálogos que serão apresentados no decorrer destas análises, a reprodução da língua francesa do século XVI; esta decisão foi tomada porque como já foi discutido, este texto em francês do século XVI é a primeira tradução do Tupinambá original, portanto, ele constitui um ponto de referência para situarmos a discussão das propostas de retradução de Aryon Rodrigues nos estudos do conceito de retradução de Yves Gambier.

A hipótese geral com a qual trabalhamos no âmbito da análise destas operações plurilíngues é que Aryon Rodrigues, experiente linguista e tradutor de línguas indígenas, apresenta uma proposta de tradução literal dos diálogos em língua francesa para o português já que esta não foi uma operação contemplada nas traduções dos linguistas Batista Caetano e Plínio Ayrosa, que se concentraram na restauração da língua Tupinambá original e em sua tradução direta para o português. Esta operação literal vem a ser um método empregado na Linguística para investigar a estrutura e o funcionamento de uma língua e, consequentemente, estabelecer o seu estado linguístico em um determinado momento da história. Ressaltamos que este método é complementar à análise descritiva, uma vez que ele é aplicado apenas no caráter filológico da língua.

Neste sentido, entendemos que esta operação tradutória, mesmo em seu caráter complementar, é fundamental na pesquisa de uma língua que não possui mais falantes e cuja documentação é escassa e pouco preservada. A tradução é entendida no sentido de uma prática para explicitar, de maneira efetiva, termos, expressões e estruturas desconhecidas da língua Tupinambá. Neste caso, podemos falar simplesmente da tradução como meio para a semantização do vocábulo (BOHUNOVSKY, 2011:211) Esta operação é um método para expandir o conhecimento sobre uma língua e o universo cultural na qual ela está envolta e que, pelos motivos citados, não pode ser acessado de outra forma. A partir do método de tradução, Rodrigues pode estabelecer, em um nível gramatical, em que medida a interpretação da língua francesa se aproxima ou se distancia da língua Tupinambá reproduzida no Colóquio 
de 1580. Esta operação é pertinente para se discutir a legitimidade deste primeiro ensaio publicado sobre a língua Tupinambá e converge com o objetivo de Rodrigues em preservar o valor documental do Colóquio.

Precisamos salientar que as operações plurilíngues de Aryon Rodrigues nem sempre são realizadas objetivamente a partir das três línguas. No entanto, esta configuração não impede que elas sejam referidas aqui como "plurilíngues", porque como demonstraremos logo adiante, todas as três línguas do Colóquio estão em constante relação umas com as outras, seja de modo direto ou indireto. A abordagem destas operações plurilíngues, portanto, será feita de acordo com a ordem em que aparecem na estrutura do Colóquio elaborada por Rodrigues, com o acréscimo da reprodução da língua francesa de Léry. Com isso, pretendemos comprovar que a ordenação das traduções nos diálogos apresentadas por Rodrigues corroboram as estratégias de tradução do linguista inseridas nas operações plurilíngues para estabelecer o conhecimento linguístico e histórico da língua Tupinambá.

A $1^{\text {a }}$ operação plurilíngue de Aryon Rodrigues consiste na restauração da língua Tupinambá reproduzida no Colóquio em 1580, através da grafia adotada pelos jesuítas no século XVII, descrita na $2^{\mathrm{a}}$ edição do Catecismo Brasílico da Doutrina Christãa (Lisboa,1686). Rodrigues justifica que a grafia jesuítica foi escolhida porque o Tupinambá restaurado seria mais facilmente lido por quem domina o português, devido aos quase dez mil vocábulos desta língua que foram incorporados à língua portuguesa falada no Brasil, principalmente aos topônimos ${ }^{95}$. Esta escolha da grafia jesuítica também tem o objetivo de facilitar o cotejo com as fontes portuguesas de conhecimento do Tupinambá. A restauração da língua Tupinambá original é aplicada em todos os 212 diálogos do Colóquio, sem exceção. ${ }^{96}$ Vejamos a seguir o diagrama que representa esta $1^{\text {a }}$ operação plurilíngue:

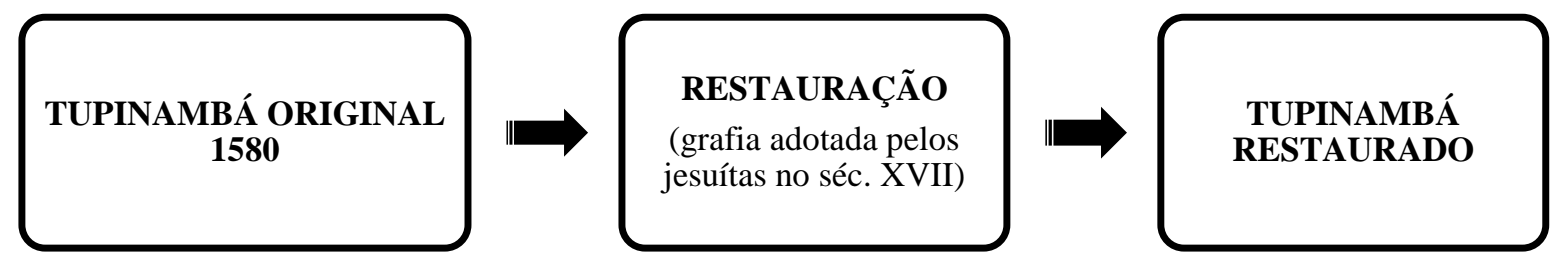

Figura 6 - Diagrama da $1^{\text {a }}$ operação plurilíngue realizada por Aryon Rodrigues Fonte: CESAR, Janaína T. G., 2016

\footnotetext{
${ }^{95}$ Cf. NAVARro, Eduardo de Almeida. Método Moderno de Tupi Antigo: A língua do Brasil dos primeiros séculos. 3. ed. São Paulo: Editora Global, 2006.

${ }^{96} \mathrm{Cf} .4^{\mathrm{a}}$ operação plurilíngue neste mesmo capítulo.
} 
A língua Tupinambá original reproduzida no Colóquio foi restaurada por Aryon Rodrigues a partir do estudo de fontes documentais dos séculos XVI e XVII, por exemplo, as gramáticas de José Anchieta Arte de grammatica da língua mais usada na costa do Brasil (1595) e de Luis Figueira Arte de grammmatica da língua brasílica (1687), e o manuscrito Vocabulário da língua brasílica (1938) coordenado por Plínio Ayrosa. No prefácio que escreveu especialmente para o Colóquio, intitulado: A contribuição linguística de Jean de Léry, afirma que o texto em Tupinambá original "apresenta uma série de dificuldades, pois a escrita de Léry, embora em geral razoável, é bastante variada na representação de certos sons da língua indígena" (RODRIGUES, 2009:44). Estas representações variadas da língua Tupinambá no texto de Léry impuseram certa dificuldade no processo de restauração, pois Rodrigues trabalha com a restauração a partir das formas mínimas (morfemas) da língua e dependia da identificação destas formas para estabelecer um parâmetro comparativo com as formas da língua Tupinambá descritas nas fontes portuguesas citadas acima. Com respeito à

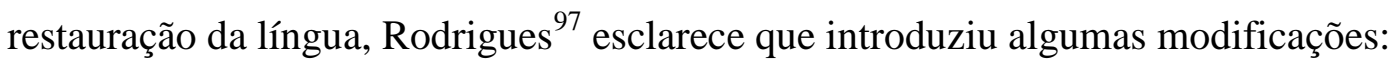

a) O trema da grafia jesuítica que marca a ocorrência do som oclusivo glotal (hiato) entre duas vogais foi substituído por um apóstrofo entre essas vogais, por exemplo: [äé] por [a'é];

b) $\mathrm{O}$ acento agudo foi substituído pelo til [ ] nas vogais tônicas que se situam no fim da palavra, quando precedidas por consoante nasal simples, por exemplo: [amó] por [amõ].

A língua Tupinambá original é identificada no Colóquio pela fonte em itálico e o Tupinambá restaurado é sempre identificado entre parênteses, por exemplo:

\section{Diálogo 183}

Emogip-caouin-amo [Faça um pouco de vinho] (eimojýb kauĩ amõ) [Cozinhe um pouco de cauin]

No Tupinambá identificado entre parênteses, podemos observar a mudança da acentuação na vogal tônica precedida pela consoante nasal simples, que foi anunciada no item b: amõ. Assim como neste exemplo, a reprodução do Tupinambá restaurado (entre parênteses) não é sempre uma fiel transposição do Tupinambá original para a grafia jesuítica, Rodrigues (2009:48) afirma que, nestes casos, trata-se de uma "tentativa de formar as frases do Tupinambá original de acordo com as regras da língua observadas nas fontes portuguesas.”.

\footnotetext{
${ }^{97}$ Ibid.:47
} 
Outro exemplo de restauração baseada nas regras da língua é o do diálogo 11: Erérou dé caramémo "Você trouxe suas malas?", na grafia jesuítica ela seria traduzida literalmente por: ererúr ndé caramemuã. Porém, Rodrigues acrescentou a partícula interrogativa enclítica - $p e^{98}$ : ererúpe ndé caramemuã, porque ele acredita que ela tenha sido omitida por um descuido na composição tipográfica do Colóquio, já que ela aparece em todos os outros diálogos.

A partir dos exemplos que apresentamos para a análise desta operação plurilíngue, podemos perceber que há nela um caráter maleável, porque Rodrigues, apesar de estabelecer uma tendência para o seu projeto de restauração, que é a grafia jesuítica, ele não se prende a uma única fonte documental para realizar este trabalho, recorrendo até mesmo a um manuscrito de autoria anônima que foi coordenado por Ayrosa, o que demonstra o caráter produtivo da crítica de Rodrigues aos trabalhos de outros linguistas; isto elimina a possibilidade de que as Críticas que ele tenha feito à Ayrosa, a respeito da restauração da língua Tupinambá e sua respectiva tradução, sejam influenciadas por um conflito de interesse, no caso, promover sua restauração e sua retradução do mesmo texto. Isto demonstra que Aryon Rodrigues não trabalha em seu próprio interesse, mas no interesse do desenvolvimento de um conhecimento linguístico.

A $2^{\mathbf{a}}$ operação plurilíngue de Aryon Rodrigues consiste na tradução literal do texto de Léry em língua francesa do século XVI, para o português atual. Após analisar o conteúdo gramatical desta tradução literal operada por Rodrigues, compreendemos que ela se aproxima do conceito de Francis H. Aubert (1987:15), a que "mantém uma fidelidade semântica estrita, adequando, porém a morfossintaxe às normas gramaticais da língua de chegada", que seria o que John C. Catford define como uma tradução sintagmática (grupo a grupo). Esta operação tradutória é o método adequado para preservar a fala dialógica coloquial da tradução em francês reproduzida no Colóquio, pois é elaborada a partir do conteúdo contido na forma da língua, e que resulta em um plano semântico, portanto, não se excede na interpretação do original em prol de uma adaptação (CATFORD,1980:28), como também não se limita à ordem da palavra, haja vista que a literalidade sintática pode reverter inteiramente a restituição do sentido e conduzir a tradução diretamente ao nonsense (BENJAMIN, 2008:62). Esta tradução literal proposta por Rodrigues permite o contato do leitor brasileiro com a

\footnotetext{
98 “Esta partícula interrogativa -pe se pospõe ao termo sobre o qual recai a pergunta" (BARBOSA, 1956:79).
} 
interpretação dada em francês ao Tupinambá original (1580). Veja no diagrama a seguir, a ilustração da $2^{\mathrm{a}}$ operação plurilíngue de Aryon Rodrigues:

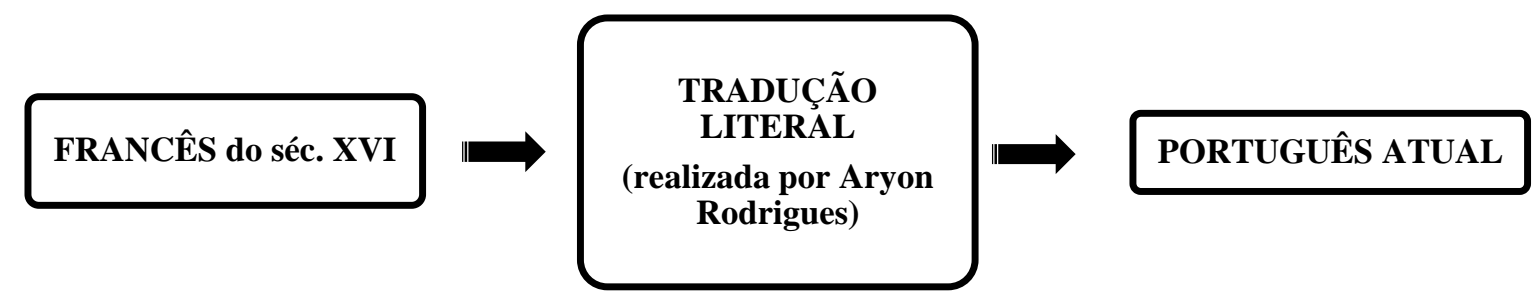

Figura 7 - Diagrama da 2a operação plurilíngue realizada por Aryon Rodrigues Fonte: CESAR, Janaína T. G., 2016

A operação ilustrada acima se configura também como a primeira retradução realizada por Rodrigues para o Colóquio. Porém, esta retradução possui um perfil diferenciado em relação ao conceito de retour [retorno] ao original discutido por Yves Gambier: a tradução literal referida nesta operação possui como texto fonte o diálogo em francês do século XVI, que já é em si uma tradução da língua Tupinambá original. A partir deste ponto de vista, a tradução literal operada por Rodrigues não seria, concretamente, o retorno à forma do original propriamente dito, porque esta forma está contida no Tupinambá original reproduzido no Colóquio em 1580. Entretanto, se considerarmos que uma tradução integral a partir da língua francesa não era publicada desde 1926, que foi a tradução de Monteiro Lobato ${ }^{99}$, podemos depreender que ela se insere sim no conceito de retour de Gambier, o ponto de retorno é operado por Rodrigues através da tradução literal - assim como Monteiro Lobato, que, excepcionalmente, se desvencilhou de suas convicções contrárias à tradução literal para "conservar as irregularidades do original" (LOBATO, M. 1926, VI) do Colóquio. Mas Monteiro Lobato logo retomou o seu posicionamento de tradução livre ao tratar os outros capítulos da obra de Léry.

Para ilustrarmos como a tradução literal de Rodrigues se alinha aos conceitos de Aubert (1987) e Catford (1980), elaboramos dois gráficos que representam um sistema de correspondência entre os modos e tempos verbais empregados na reprodução original em francês (1580) e a sua tradução literal para o português realizada por Rodrigues (2009). Para evitarmos a repetição dos dados discutidos no capítulo 1 , que se refere aos tempos verbais do Colóquio de acordo com a gramática francesa de Charles Maupas, nos limitaremos aqui em discutir os dados do gráfico que representa o uso dos tempos verbais na tradução literal do francês para o português e o gráfico que representa o confronto dos tempos verbais do francês

\footnotetext{
${ }^{99}$ Ver no capítulo 2 deste trabalho, o ponto 2.2.3 Monteiro Lobato (1926).
} 
e de sua respectiva tradução para o português, a fim de verificarmos em que nível a tradução de Rodrigues se mantém literal ao texto em francês do século XVI. O levantamento de dados de ambos gráficos é baseado em uma amostra de 96 diálogos, desdobrados em 127 enunciados. Estes $127^{100}$ enunciados são os que possuem a estrutura mais completa do Colóquio elaborado por Aryon Rodrigues na edição de 2009, porque eles contêm os dois textos em língua Tupinambá e suas respectivas traduções para o português. Vejamos a seguir o $1^{\circ}$ gráfico:

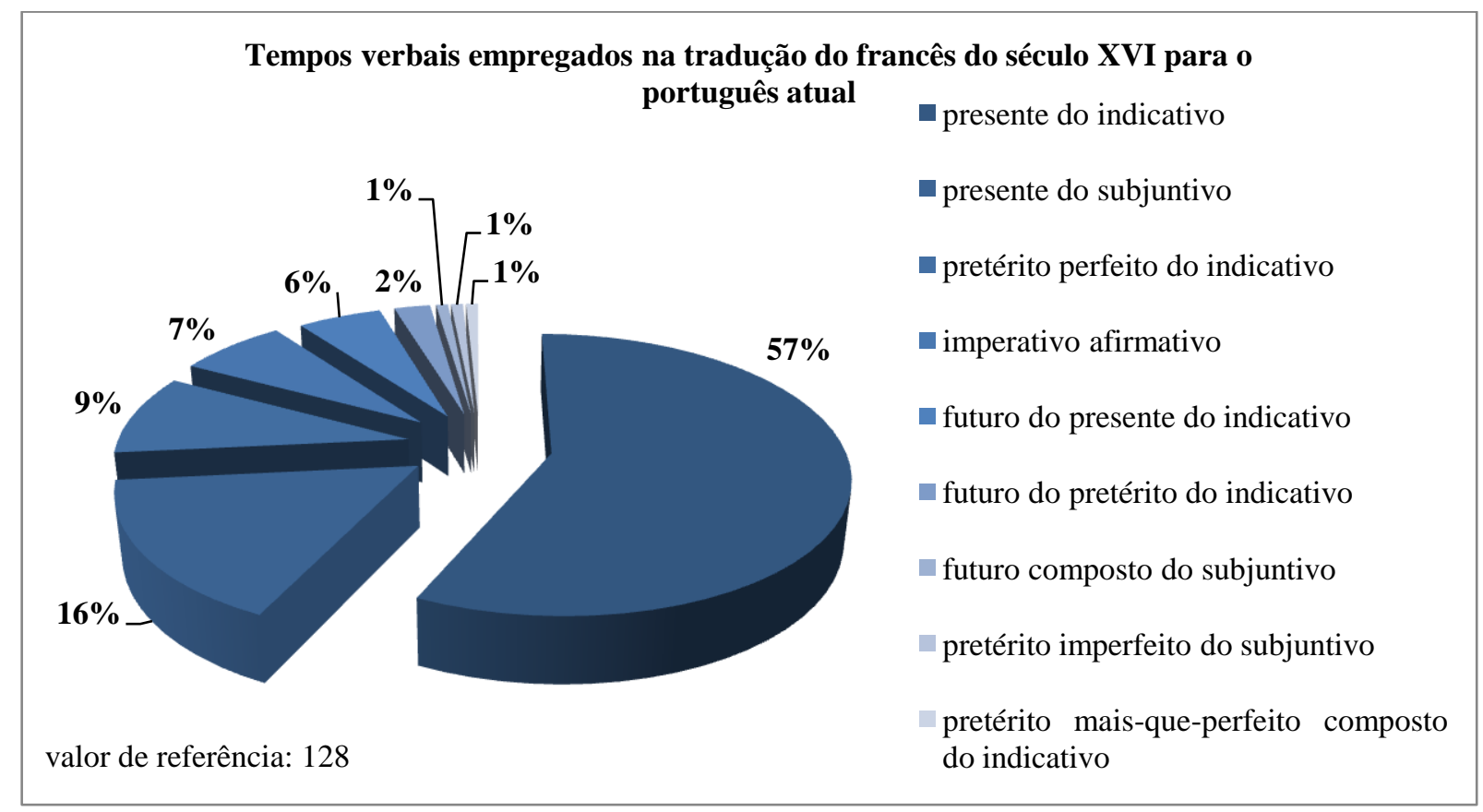

Figura 8 - Representação dos tempos verbais empregados na tradução literal do francês do século XVI para o português atual.

Fonte: CESAR, Janaína. T. G., 2016

Com relação aos dados apresentados neste primeiro gráfico, podemos perceber que os 9 tempos verbais empregados na tradução de Rodrigues se igualam quantitativamente aos 9 tempos verbais empregados no texto em francês ${ }^{101}$, mesmo considerando que esta análise dos tempos verbais ficou limitada aos 127 enunciados agrupados em 96 diálogos. Os tempos verbais mais frequentes na $2^{\mathrm{a}}$ operação plurilíngue de Aryon Rodrigues são o presente do indicativo (57\%) e o presente do subjuntivo (16\%), que correspondem de modo praticamente igualitário aos tempos verbais nos diálogos em francês, o indicatif présent (58\%) e l'optatif présent $(15 \%)$. Estes valores são suficientemente concretos para deduzirmos que a $2^{\mathrm{a}}$ operação plurilíngue de Aryon Rodrigues é fundamentalmente literal. Mas, para obtermos

\footnotetext{
${ }^{100}$ Este número de amostra se repete na análise dos gráficos da $3^{\mathrm{a}}$ operação plurilíngue.

${ }^{101}$ Cf. Gráfico 1 no capítulo 2 deste trabalho.
} 
uma conclusão irrefutável desta operação, precisamos ter um panorama destas correspondências entre os tempos verbais, no âmbito da amostra de 127 enunciados. Esta informação poderá ser confirmada no gráfico a seguir; vejamos o $2^{\circ}$ gráfico que representa a $2^{\mathrm{a}}$ operação plurilíngue de Aryon Rodrigues:

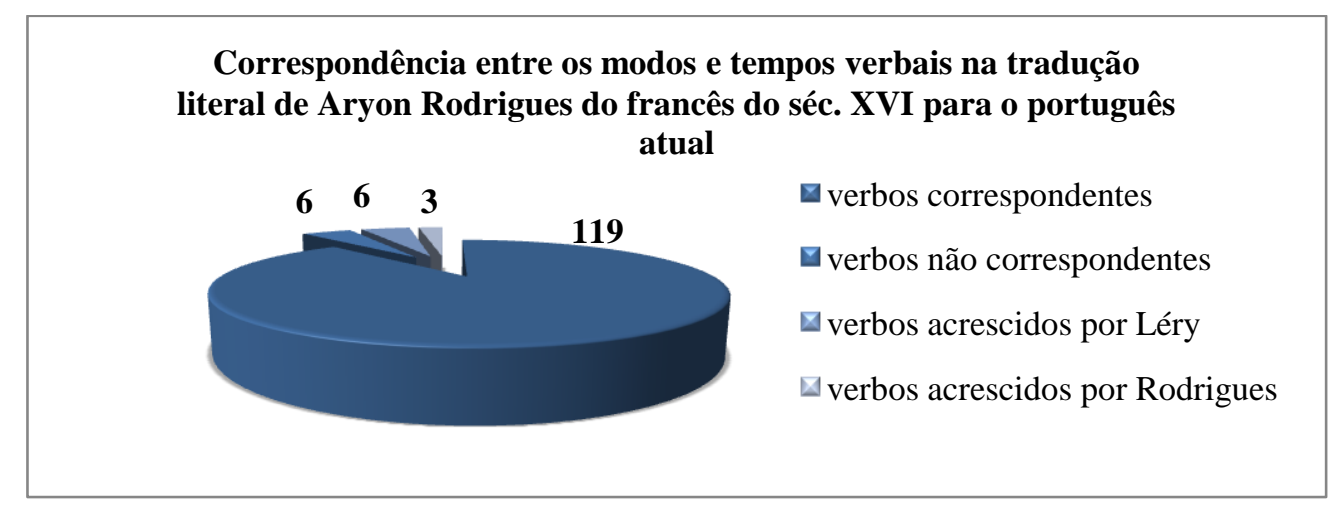

Figura 9 - Representação das correspondências entre os tempos verbais que formam a compõem a $2^{\mathrm{a}}$ operação plurilíngue de Aryon Rodrigues.

Fonte: CESAR, Janaína. T. G., 2016

A partir das informações quantitativas de correspondência entre os verbos empregados no texto em francês e sua respectiva tradução para o português, cabe mencionarmos que os verbos em francês somam 130 no total, e os verbos na sua respectiva tradução somam 128 no total. A partir deste referencial, podemos afirmar o caráter literal da tradução de Rodrigues nesta $2^{\mathrm{a}}$ operação plurilíngue. Esta afirmação se consolida nos 119 verbos que, analisados um a um, correspondiam ao tempo verbal empregado no texto em francês; quanto aos 6 tempos verbais que não são correspondentes, eles apenas reforçam que a tradução de Rodrigues definitivamente não é livre e, muito menos palavra por palavra; estes 6 verbos não correspondentes somados aos 3 verbos acrescidos na tradução de Rodrigues apenas comprovam que ele adequou em sua tradução o texto fonte às normas morfossintáticas da língua portuguesa. Vejamos no quadro a seguir um exemplo desta operação plurilíngue de tradução literal realizada por Aryon Rodrigues:

\section{Diálogo 100}

C'eft le mõde qui nous eft pour noftre bien. C'eft qui nous donne de fes biens. [É gente que quer nosso bem; são quem nos dá seus bens.]

A partir do exemplo do diálogo mostrado acima e dos dados apresentados nos gráficos desta operação, inferimos a hipótese de que a $2^{\mathrm{a}}$ operação plurilíngue de Aryon Rodrigues busca transpor para a língua portuguesa, em um nível semântico, o discurso do viajante 
francês, tal como pode ser verificado nos diálogos em francês. Esta operação literal tem por objetivo fornecer ao leitor brasileiro a experiência mais próxima possível do que ele poderia ter ao ler o original em francês. Graças a esta tradução podemos perceber todo o estranhamento expressado pelo viajante francês ao se deparar com a Realia dos índios Tupinambá, seja nas descrições dos elementos culturais, ou dos nomes pertencentes à fauna e flora.

Com respeito à tradução para o português do texto em francês reproduzido no Colóquio de 1580, ela foi contemplada apenas nas traduções de Tristão de Araripe e Monteiro Lobato, publicadas, respectivamente, em 1889 e 1926. A partir de uma leitura da tradução para o português de Monteiro Lobato, é correto avaliarmos que ela envelheceu ${ }^{102}$, marcada por uma ortografia ultrapassada e por palavras que já caíram em desuso. Neste sentido, a proposta de uma tradução que contemple a língua francesa presente no Colóquio de Léry é necessária, na medida em que este texto clássico e de valor histórico e linguístico só poderia sobreviver ${ }^{103}$ por meio da tradução, promovendo e preservando o conhecimento da cultura e da língua dos índios Tupinambá para novas gerações de leitores.

A $3^{\mathbf{a}}$ operação plurilíngue de Aryon Rodrigues consiste na tradução literal da língua Tupinambá restaurada para o português atual. Rodrigues esclarece que o objetivo desta operação é fornecer uma interpretação a partir da língua Tupinambá, nos casos em que Léry apresenta uma tradução um pouco livre em relação à frase da referida língua (RODRIGUES, 2009:47). Esta operação plurilíngue é compreendida também como a $2^{a}$ retradução realizada por Rodrigues em 2009; esta retradução se refere à tradução de Plínio Ayrosa para o Colóquio (1941), que possui a mesma estrutura básica da operação de Rodrigues, mas não os mesmos referenciais teóricos para realizar a restauração do Tupinambá. Vejamos no diagrama a seguir a representação da $3^{\text {a }}$ operação plurilíngue:

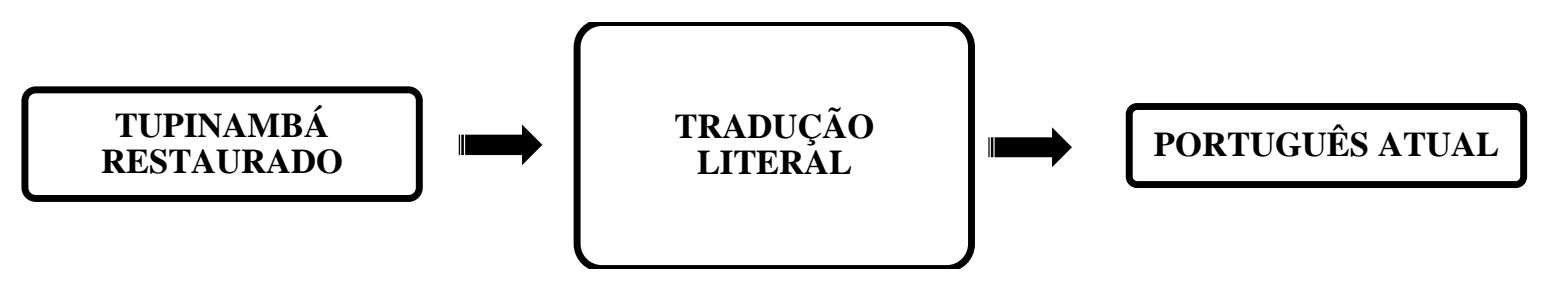

Figura 10 - Diagrama da $3^{\mathrm{a}}$ operação plurilíngue realizada por Aryon Rodrigues

Fonte: CESAR, Janaína T. G., 2016

${ }^{102}$ Cf. p. 24 deste trabalho.

${ }^{103}$ Cf. p. 14 deste trabalho. 
Anteriormente, podíamos depreender da fala de Rodrigues que esta operação de tradução literária ocorria a partir da língua Tupinambá de 1580. Entretanto, percebemos que esta situação não é coerente com a proposta de restauração da forma e do conteúdo da língua, pois de que maneira Rodrigues poderia classificar a tradução de Léry como livre, antes mesmo de analisar a estrutura da língua reproduzida em 1580 e restaurar seu conteúdo e forma? Há um fator que corrobora nossa afirmação de que esta tradução literal parte do Tupinambá restaurado: Rodrigues faz uma distinção muito importante na composição tipográfica do Colóquio colocando entre parênteses todos os textos que foram acrescentados por ele - língua Tupinambá restaurada e tradução literal que parte do Tupinambá para o português - criando uma relação direta entre estes dois textos. A partir desta composição, Rodrigues (2009:47) justifica que "os parênteses permitem ao leitor distinguir claramente o que ficou registrado na obra de Léry da interpretação que lhe demos, seja quanto à forma de expressão em Tupinambá, seja quanto ao seu conteúdo vertido para o francês e deste para o português.". Ao optar por distinguir estas interpretações, Rodrigues dá visibilidade ao seu projeto de restauração linguística e à sua nova interpretação do Colóquio sem interferir no conteúdo apresentado por Léry. Veja no quadro a seguir, um exemplo desta configuração tipográfica elaborada por Rodrigues:

159. T Yporrenc-pe-peretani? (iporángpe pé retáma) O lugar em que vocês vivem é bonito $^{104}$ ? (É bonita a terra de vocês?)

O formato e a sequência da enunciação do índio Tupinambá (identificado pela letra "T" após a numeração do diálogo) apresentados no exemplo acima são a representação fiel de como os diálogos são dispostos no Colóquio publicado em 2009. Esta distinção tipográfica de Rodrigues foi uma contribuição fundamental para separarmos, com exatidão, os dados dos diálogos, analisando-os e classificando-os no âmbito das operações plurilíngues abordadas neste trabalho.

A partir das informações citadas acima, passaremos à análise quantitativa desta $3^{\mathrm{a}}$ operação plurilíngue de Rodrigues; a principal característica desta operação reside no fato de que todos os 212 diálogos do Colóquio foram restaurados para a língua Tupinambá, assim como vimos na descrição da $1^{\text {a }}$ operação plurilíngue; dentre estes 212 diálogos, 96 são resultado da operação plurilíngue de tradução literal do Tupinambá restaurado para o

\footnotetext{
${ }^{104}$ No original em francês do século XVI: "Le lieu dont vous eftes eft il beau?"
} 
português atual. Cabe aqui esclarecermos que cada diálogo pode conter mais de um enunciado em língua Tupinambá, portanto, a partir de um levantamento, constatamos que os 212 diálogos desdobram-se em 367 enunciações no total, a partir deste valor, calculamos que 127 enunciados (inseridos nos 96 diálogos) foram trabalhados por Aryon Rodrigues no âmbito da $3^{\mathrm{a}}$ operação plurilíngue, ou seja, foram traduzidos a partir de uma nova interpretação da língua Tupinambá restaurada. Vejamos no gráfico a seguir, a comparação entre o percentual de enunciados traduzidos a partir da $3^{\mathrm{a}}$ operação plurilíngue e o percentual de enunciados que não foram contemplados na referida operação:

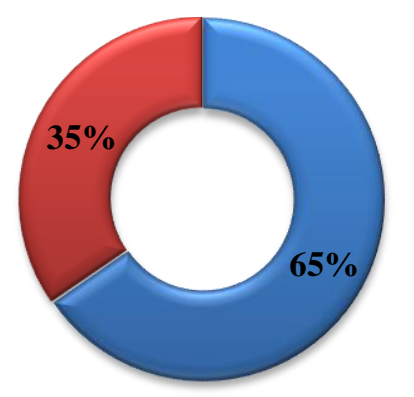

\author{
๑enunciados não traduzidos \\ ๑enunciados traduzidos a partir do \\ Tupinambá restaurado \\ valor de referência: 367
}

Figura 11 - Representação dos enunciados que compõem a $3^{\mathrm{a}}$ operação plurilíngue Fonte: CESAR, Janaína. T. G., 2016

Através do gráfico apresentado acima, podemos observar que as enunciações traduzidas literalmente a partir do Tupinambá restaurado (35\%) não prevalecem sobre o número de enunciados que não contém esta mesma tradução. Isto ocorre porque, de acordo com Aryon Rodrigues, não foi possível identificar algumas formas da língua Tupinambá original, por isso, ele optou por deixar lacunas em $65 \%$ destes enunciados (RODRIGUES, 2009:48). Estas lacunas dizem muito sobre a postura de Aryon Rodrigues em relação ao tratamento dado à língua Tupinambá nas operações plurilíngues: elas remetem a uma limitação que todo linguista pode encontrar ao lidar com a restauração de línguas indígenas que não possuem mais falantes e cujas documentações se encontram em um estado precário de preservação, ou com erros na composição tipográfica do manuscrito, que é o caso da edição de 1580 da obra de Jean de Léry. Ao se limitar a traduzir apenas 35\% dos enunciados, entendemos que Aryon Rodrigues assume uma postura ética frente à interpretação da língua Tupinambá para o português, uma postura que não o permite tomar liberdades criativas, que o mantém no foco de preservação do conhecimento linguístico. Do mesmo modo, sua tradução literal da língua Tupinambá restaurada pode ser vista na perspectiva de Berman (2007:69) como "pertencente originalmente à dimensão ética", pois preserva na tradução a fidelidade ao 
texto de partida. Em todo caso, Rodrigues já demonstrou que possui competência linguística para sustentar seu posicionamento ético.

Retomando a explicação da estrutura desta operação plurilíngue, Rodrigues anuncia que ela, assim como a $2^{\mathrm{a}}$ operação, foi realizada através do método de tradução literal, em resposta à tradução livre de Léry para a língua Tupinambá original. No que diz respeito ao conceito de tradução livre, nos alinhamos à definição elaborada por Catford (1980:28), que a caracteriza como sendo uma "adaptação lexical a requisitos de associação ou 'idiomáticos' da Língua Meta (LM) [...]; que se inclina para uma equivalência de frases inteiras." Vejamos no quadro a seguir um exemplo desta tradução livre de Léry, a qual Rodrigues se refere:

\section{Diálogo $178^{105}$}

Erout-che-rata-rem Traga com que acender meu fogo. (erúr xé ratáráma) (Traga meu futuro fogo.)

Para compreendermos o motivo pelo qual Rodrigues classificou este enunciado como sendo uma tradução livre, precisamos fazer uma breve análise morfológica desta oração. De acordo com O pequeno vocabulário português-tupi (1970), desenvolvido pelo Pe. Lemos Barbosa, o substantivo "fogo" em tupi se escreve atá e pode se relacionar com os verbos: fazer, pegar, tocar, tirar (1970:107); já o verbo irregular "trazer" em tupi se escreve rura (ibid., 201). De acordo com Rodrigues (2010:22), "em composição atributiva com outros substantivos, rám e pwér são empregados com grande frequência para indicar uma coisa que ainda não alcançou seu estado normal", portanto, ao isolarmos o substantivo atá e o sufixo rám possuímos então a construção "futuro fogo". A presença do alomorfe -e do sufixo pessoal -ere ( $3^{\mathrm{a}}$ pessoa não focal - "você"), e a ausência do sufixo modal $(\varnothing)$, caracteriza o modo imperativo do verbo rur, que formam erúr "traga". Por fim, a primeira pessoa do singular xé "meu", que é usado na construção possessiva. Como podemos perceber o Tupinambá original reproduzido por Léry, possui construções semelhantes à de Rodrigues, mas escrita em uma grafia diferente. Mesmo assim, Léry acrescenta em sua tradução o verbo "acender", que em tupi se escreve mondyca (referente ao substantivo fogo) ${ }^{106}$, e elimina a ideia de futuro no sufixo que ele escreve como rem, que determina que o fogo ainda será fogo.

Com base nesta nova proposta de tradução literal por Aryon Rodrigues, decidimos fazer um levantamento dos tempos verbais de ambas traduções por ele realizadas para o

\footnotetext{
${ }^{105}$ O diálogo 177 apresenta o seguinte texto: Emo-goep-tata (eimoguéb tatá) "Eftein le feu." Apague o fogo.

${ }^{106}$ Cf. BARBOSA, Pe. A. Lemos. Pequeno vocabulário Português - Tupi. Rio de Janeiro: Livraria São José, 1970 , p. 19.
} 
português ${ }^{107}$ e confrontá-las com o objetivo de investigarmos em que medida as interpretações dadas a estas traduções se distanciam ou se aproximam. Este estudo busca estabelecer se o texto reproduzido em francês no Colóquio de Léry, traduzido literalmente para o português, realmente corresponde ao texto que é a fonte da sua tradução, o Tupinambá original. Após realizarmos o levantamento dos tempos verbais em cada tradução para o português chegamos aos seguintes valores: a tradução literal do francês do século XVI para o português atual possui 128 verbos; a tradução literal da língua Tupinambá restaurada para o português atual possui 98 verbos no total. Logo de início percebemos que esta diferença quantitativa calculada em 30 verbos é bem significativa, porque nos remete novamente à discussão ${ }^{108}$ da necessidade que o colonizador renascentista tem em tornar a língua indígena Tupinambá mais inteligível, mais distante do selvagem e mais próxima do valor ocidental de civilização, seja a partir do estabelecimento de uma grafia ou criação de uma gramática. Veremos a seguir um gráfico que representa os tempos verbais empregados por Rodrigues em sua tradução literal do Tupinambá restaurado:

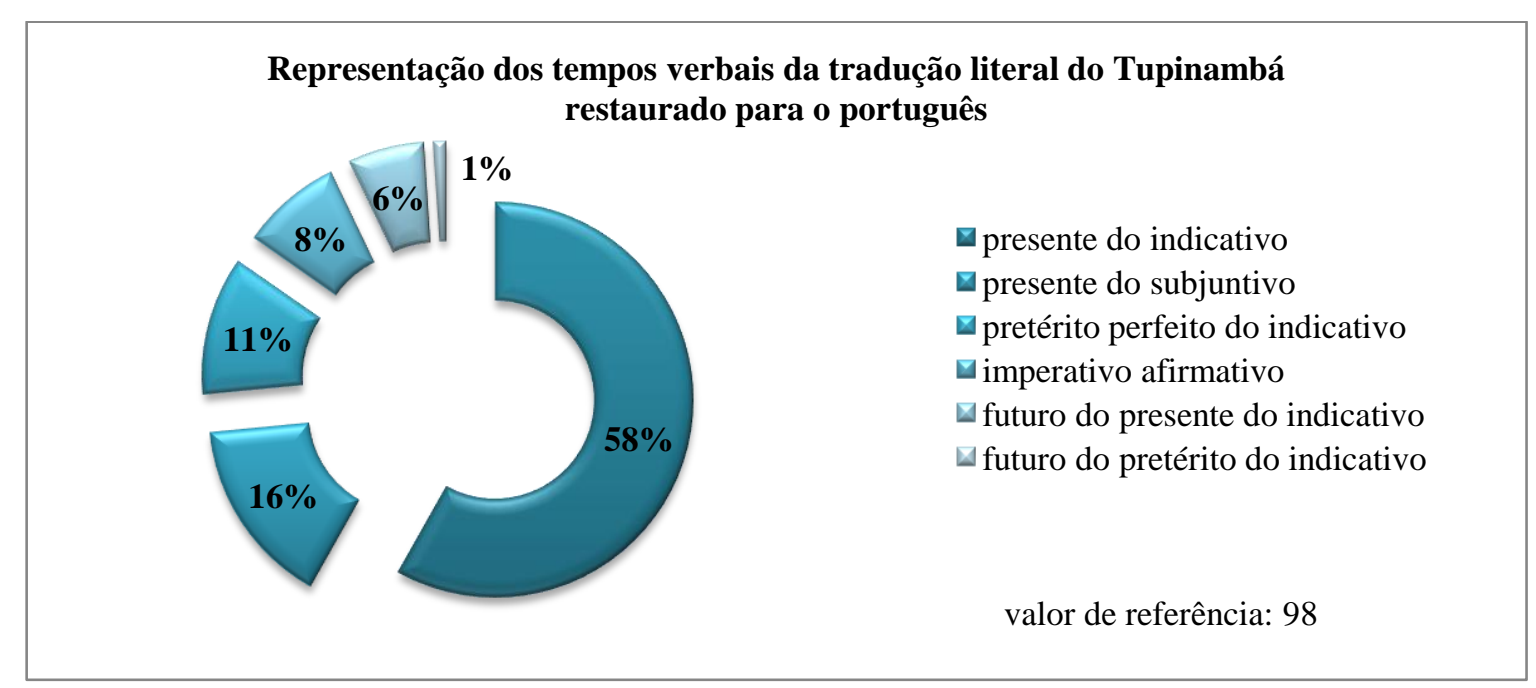

Figura 12 - Representação dos tempos verbais da $3^{\mathrm{a}}$ operação plurilíngue realizada por Aryon Rodrigues Fonte: CESAR, Janaína T. G., 2016

Os dados quantitativos que podemos depreender do gráfico acima demonstram que a quantidade de tempos verbais empregados na tradução do Tupinambá restaurado (6) é relevantemente pequena em comparação a quantidade dos tempos verbais empregados na tradução do francês do século XVI (9). Para não tornarmos esta discussão muito repetitiva, não exibiremos novamente o gráfico dos tempos verbais empregados por Rodrigues na

\footnotetext{
${ }^{107}$ Cf. $2^{\text {a }}$ operação plurilíngue, neste capítulo.

${ }^{108}$ Cf. capítulo 2 deste trabalho.
} 
tradução literal do francês do século XVI para o português atual, porque ele já foi discutido na análise da $2^{\mathrm{a}}$ operação plurilíngue de Aryon Rodrigues, mas demonstraremos a seguir o resultado quantitativo da comparação entre os tempos verbais utilizados nas duas traduções para o português de Rodrigues:

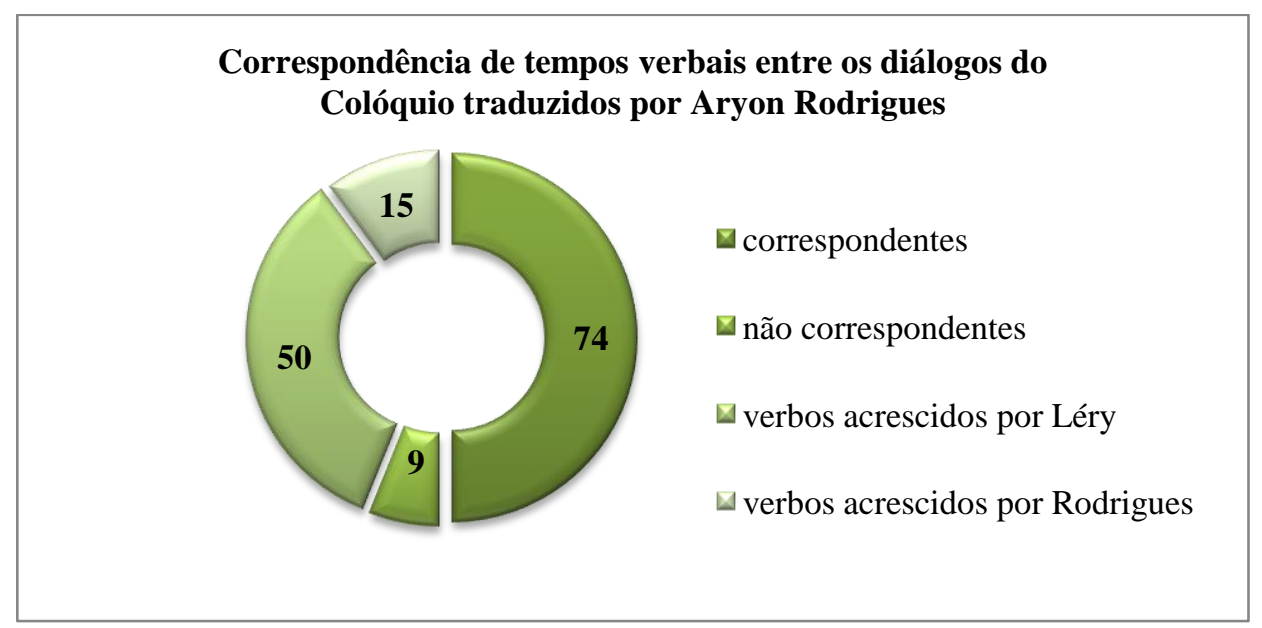

Figura 13 - Resultado quantitativo das correspondências entre os tempos verbais das duas traduções de Rodrigues para o português atual. Fonte: CESAR, Janaína T. G., 2016

A informação que podemos depreender do gráfico acima é que a diferença de 30 verbos que constatamos no levantamento de dados geral sobre as duas traduções pode ser vista, claramente, no levantamento dos verbos não correspondentes, que somam o número significativo de 50 verbos traduzidos do Tupinambá restaurado para o português que não possuem nenhuma relação com os tempos verbais empregados na tradução literal do francês do século XVI. O número expressivo de 15 verbos que foram acrescidos por Jean de Léry e que não aparecem na tradução do Tupinambá restaurado, é uma representação das descrições contidas na tradução do francês - estratégia muito comum em uma tradução que envolve duas línguas muito distantes culturalmente, aplicada para lidar com os estranhamentos lexicais da língua fonte na tradução para a língua meta. Por exemplo, como quando Léry traduz no diálogo 60: "paca" (na tradução do Tupinambá restaurado) por "é um animal do tamanho de um porquinho de um mês, rajado de branco e preto".

Após a análise da $3^{\mathrm{a}}$ operação plurilíngue de Aryon Rodrigues, trabalhamos com a hipótese de que ela é o resultado concreto e positivo da restauração da língua Tupinambá trabalhada na $1^{a}$ operação plurilíngue. Esta nova tradução para o português, resulta em um 
enriquecimento do conhecimento sobre a realia ${ }^{109}$ dos índios Tupinambás e suas diferentes formas de comunicação, como demonstramos no exemplo do diálogo 178. Numa análise comparativa desta tradução a partir do Tupinambá restaurado e a tradução literal da língua francesa, podemos perceber que esta $3^{a}$ operação nos revela ainda os diversos elementos que foram adaptados à cultura do público-leitor da obra de Léry.

A seguir, trataremos da última operação plurilíngue identificada no projeto etnolinguístico de Aryon Rodrigues, relacionada à restauração da língua Tupinambá por meio da tradução do Colóquio entre as gentes do país.

A 4a operação plurilíngue de Aryon Rodrigues suscita umas das questões mais interessantes para a discussão deste trabalho, ela se refere ao método utilizado para concretizar o projeto de restauração da língua Tupinambá do Colóquio. Durante a operação de restauração da língua Tupinambá realizada a partir do Tupinambá original reproduzido por Léry, Rodrigues se deparou com alguns casos em que não foi possível identificar todos os detalhes do registro da língua Tupinambá original (1580). Para superar esta barreira linguística, recorreu ao método de tradução para restaurar o sentido da língua Tupinambá, optando por traduzir para o Tupinambá restaurado o sentido fornecido em francês por Léry (RODRIGUES, 2009:48).

Vejamos no diagrama a seguir a representação desta operação:

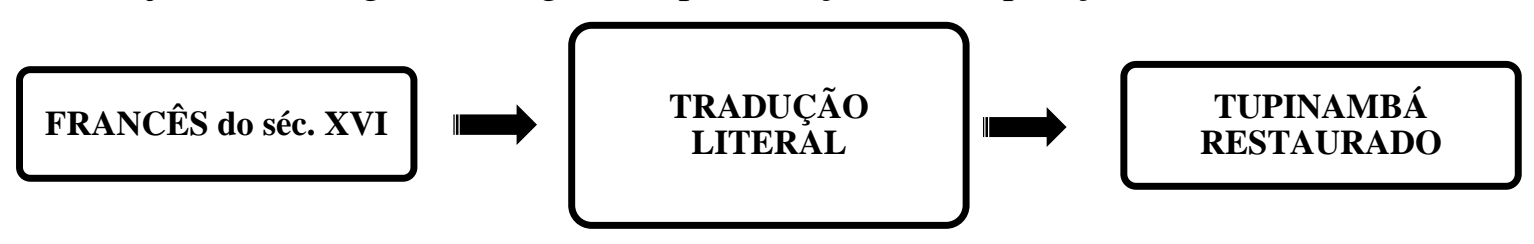

Figura 14 - Diagrama da $4^{\mathrm{a}}$ operação plurilíngue realizada por Aryon Rodrigues Fonte: CESAR, Janaína T. G., 2016

Como mencionamos na discussão da $3^{\mathrm{a}}$ operação plurilíngue, Aryon Rodrigues operou a restauração completa dos diálogos do Colóquio em Tupinambá original, mas a concretização desta restauração não seria possível se Rodrigues não tivesse recorrido à interpretação de Léry do Tupinambá original. Rodrigues (2009:44) argumenta que este procedimento foi necessário porque durante a composição tipográfica da edição de 1580 , foram introduzidos "numerosos erros de leitura do manuscrito, o que levou a uma descaracterização em diferentes graus de muitas palavras" da língua Tupinambá. As falhas mais frequentes consistem na troca de uma letra por outra, estes erros ficam mais evidentes quando efetuamos a leitura do manuscrito. As letras que mais sofreram falhas são: a letra $n$

\footnotetext{
${ }^{109}$ Cf. SAUSSURE, Ferdinand de. Curso de Linguística Geral. São Paulo: Cultrix, 2006, p. 30.
} 
trocada pela letra $u$ ou vice-versa, a letra $h$ por $k, e$ por $c, n i$ ou in por $m, g$ por $q, c$ por $r, r$ por $v$. Estas foram algumas das dificuldades que Rodrigues precisou superar para identificar no texto de Léry as "formas da língua Tupinambá tal como as conhecemos de outras fontes dos séculos XVI e XVII" ${ }^{110}$.

No entanto, Rodrigues pondera que, no âmbito de um confronto geral entre o texto no Tupinambá original e as fontes documentais portuguesas da referida língua, as formas reproduzidas no Colóquio publicado por Léry são facilmente identificáveis, o que no seu entendimento "diz bem da legitimidade não só do texto, mas também da sua tradução" 111. Esta fala de Rodrigues constitui uma crítica direta ao comentário que Plínio Ayrosa teceu em sua "Nota prévia" à tradução do Colóquio sobre a interpretação da língua Tupinambá a partir do francês. Ayrosa afirma que "a nossa tentativa, evidentemente ousada, de dar em português o que realmente está escrito em língua brasílica e não o que tem sido dado por intermédio da interpretação mais ou menos vaga do próprio Léry" (LÉRY, 2007:271).

Rodrigues, então, tendo atestado a legitimidade em grande parte dos casos, da interpretação em língua francesa para a língua Tupinambá, põe em prática esta operação plurilíngue para concluir seu projeto de restauração da língua Tupinambá original. Vejamos no quadro a seguir um exemplo desta restauração a partir da interpretação do texto francês:

\section{Diálogo 98 (T)}

(Teh? Oioac poeireca á paau ué, iende eu)

Le monde cherche l'vn l'autre \& pour noftre bien.

[As pessoas procuram umas às outras, e para o nosso bem.]

(té, ojoecár apyába jandébe)

(Que bom, as pessoas procuram umas às outras em nosso benefício.)

A dificuldade de Rodrigues em traduzir este diálogo diretamente do Tupinambá original se encontra no trecho: oioac poeiraca; Rodrigues acredita que este trecho dificilmente seria um registro deturpado de ojoecár "procuram uns aos outros". Neste caso, Rodrigues afirma não ter conseguido identificar a forma reproduzida por Léry. Este e outros detalhes que não puderam ser identificados por Rodrigues em outros diálogos foram restaurados através da interpretação da tradução francesa. O fato deste detalhe no registro de Léry não ter sido identificado não compromete totalmente a compreensão do restante da estrutura da frase, porque como vimos na $1^{\mathrm{a}}$ operação plurilíngue, Rodrigues trabalha com as

\footnotetext{
110 ibid.:44.

111 ibid.:48.
} 
formas mínimas (morfemas) para restaurar uma língua em um determinado estado linguístico. E agora, como podemos depreender da análise da $4^{\mathrm{a}}$ operação plurilíngue, também usa o método da tradução para resgatar formas que foram descaracterizadas no texto. Este método, no entanto, não é adequado para todos os casos, assim como vimos na operação plurilíngue anterior, nos diálogos que se encerram com uma lacuna na questão da tradução do Tupinambá restaurado para o português atual.

Esta $4^{a}$ operação corrobora a afirmação discutida no início deste trabalho, pela qual nos posicionamos a favor do uso do termo "plurilíngue" em todas as operações que aparentemente não envolviam mais de duas línguas no processo em que se situavam. Ficou provado que todas as três línguas envolvidas neste jogo de forças tradutórias, continuaram estabelecendo contato umas com as outras, de forma direta ou indireta, para se desenvolverem cada qual na sua operação. Esta característica dinâmica da relação entre as línguas no âmbito das operações plurilíngues de Aryon Rodrigues reforça o fato de que, para trabalhar a restauração da forma e do conteúdo de uma língua, não devemos nos prender a métodos restritos e engessados, que não dialogam com este caráter dinâmico intrínseco da linguagem humana.

Objetivamos demonstrar neste capítulo que Rodrigues soube orquestrar esta maleabilidade das operações plurilíngues a favor do conhecimento científico da língua Tupinambá, recorrendo a outros métodos inseridos no campo de estudos da linguística, como a tradução, que se insere nos estudos da Linguística Aplicada; demonstramos também que a partir do exercício contínuo da tradução, podemos adquirir conhecimento sobre a estrutura de uma língua e compreender seu funcionamento mesmo nas menores unidades de significação. Ademais, concluímos que Aryon Rodrigues foi estratégico nas suas operações plurilíngues, ao utilizar o método da tradução literal para preservar o conteúdo e a forma da língua para a qual desejava verter e, ao mesmo tempo, observando o funcionamento da estrutura da língua a partir da tradução. Não podemos deixar de admitir também que o conhecimento e a competência linguística de Aryon Rodrigues foram de grande valia para que todas estas operações pudessem ser concretizadas de forma a convergir para um só objetivo: o conhecimento da Língua Brasílica. 


\section{CONSIDERAÇÕES FINAIS}


O Colóquio entre as gentes do país encontra sua importância nas diversas áreas do conhecimento, por exemplo, História, Antropologia, Literatura, Linguística e os Estudos da Tradução; mas para Aryon Rodrigues, enquanto linguista especialista nos estudos descritivos e histórico-comparativos das línguas indígenas, sua importância é medida por seu valor documental, no sentido de que o texto do Colóquio é o primeiro ensaio publicado sobre aspectos da gramática de uma língua indígena brasileira. Vimos ao longo deste trabalho, o desenvolvimento da pesquisa científica de Aryon Rodrigues por meio de sua proposta de restauração e de retradução da língua Tupinambá original de 1580. O objetivo principal deste estudo é contribuir para o acréscimo de um conhecimento linguístico e um conhecimento humano, no âmbito do estudo do estado da língua Tupinambá no período do Brasil Colônia. Este estudo é um desdobramento do interesse de Rodrigues em relação à preservação e elaboração de documentações sobre a língua e a história dos índios Tupinambá, porque elas são raras e algumas se perderam com o passar dos séculos. Embora a língua Tupinambá não possua mais falantes - considerada uma língua extinta, devido à sua dizimação durante o processo colonizador, Rodrigues reforça que todo conhecimento descoberto através das investigações das línguas indígenas contribui para a expansão da compreensão que se tem sobre as diversas manifestações da linguagem humana. É isto que representa a principal razão pela qual Aryon Rodrigues se envolveu na tarefa de restaurar e fornecer uma nova interpretação da fala do índio Tupinambá, após investigar a estrutura da língua a partir de uma análise sincrônica, complementada pelo método da tradução literal, para alcançar um conhecimento que não pode ser extraído de formas descaracterizadas por erros tipográficos e formas que não puderam ser interpretadas como pertencentes às da língua, devido às diversas variações de escrita usadas para transcrever o Tupinambá.

O missionário calvinista Jean de Léry também possui grande mérito no que diz respeito à expansão do conhecimento sobre a Realia dos índios Tupinambá no século XVI, porque foi graças ao seu empenho em realizar anotações sobre a língua e a cultura dos índios Tupinambá na sua obra História de uma viagem feita à terra do Brasil, é que hoje temos acesso a uma documentação de grande valia, precursora da etnografia nos idos da colonização do Brasil, antes mesmo desta ciência existir. Desenvolvemos nesta pesquisa, a hipótese da autoria compartilhada do Colóquio entre as gentes do país, no qual os truchements assumem a importante função de compilar um guia de conversação franco-tupi, a partir das transcrições, anotações e descrições das palavras da língua Tupinambá, e de divulgá-lo para outros viajantes e missionários. A investigação da história do relacionamento destes truchements 
com os índios Tupinambá, também nos revelou o endotismo destes jovens franceses, abandonados em um Novo Mundo, que se aliam aos índios e renegam sua própria cultura nativa, chegando a sabotar internamente as operações colonizadoras francesas.

A investigação da intencionalidade da escrita da língua dos índios Tupinambá pelos missionários revelou o desejo de produzir e estruturar a consciência do índio, tornar inteligível a sua oralidade, torná-la mais civilizada, o que foi denominado de conversão linguística. Esta conversão é orientada em detrimento da visão de mundo o homem europeu do século XVI e da recepção da obra por seu público leitor. Na visão eurocêntrica, compartilhada no século XVI notoriamente pelos europeus colonizadores, o relato de viagem de Jean de Léry alcançou grande destaque e passou a ser visto como um referencial do que era a realidade no Novo Mundo.

A metodologia das operações plurilíngues realizada por Aryon Rodrigues permitiu que construíssemos uma nova visão sobre a Realia dos índios Tupinambá que habitavam a costa brasileira no século XVI. O tratamento que Aryon Rodrigues propôs ao texto do Colóquio publicado por Jean de Léry, foi objetivo desde o princípio, porque ele estabeleceu uma Crítica produtiva em relação aos trabalhos de tradução e restauração anteriores ao dele. Certamente, isto foi em grande parte possível porque seu projeto de restauração e retradução se encontravam, na época de sua feitura, em uma posição mais privilegiada em relação aos trabalhos publicados por Batista Caetano e Plínio Ayrosa, já que Rodrigues teve acesso a diversos recursos de pesquisa, por exemplo, os dicionários jesuítas publicados sobre a língua Tupinambá. A formação na Linguística e os marcos teóricos de Aryon Rodrigues também são cruciais para a realização deste trabalho.

O projeto etnolinguístico de Aryon Rodrigues, operado através da retradução para o português da língua francesa - que há muito tempo não era retraduzida -, e da língua Tupinambá restaurada contribuiu para que o próprio leitor desta edição brasileira pudesse desenvolver um senso crítico e, ao mesmo tempo, um olhar compassivo sobre o texto do Colóquio, porque a partir do confronto da leitura de ambas retraduções, pudemos identificar as operações de tradução descritiva e tradução etnocêntrica de Jean de Léry, além de estabelecer que eles foram necessários para lidar com o estranhamento dos elementos extralinguísticos presentes na estrutura textual do Colóquio entre as gentes do país. A partir da análise destas retraduções de Aryon Rodrigues, inseridas nas operações plurilíngues, podemos concluir que "retraduzir não é substituir nem tampouco suceder, mas acrescentar, pluralizar. Entendemos que o espaço da retradução é um espaço de coexistência, e não de 
substituições" (MATTOS, 2014:52). Neste sentido, podemos concluir que o estudo do projeto etnolinguístico de Aryon Rodrigues contribuiu significativamente para uma mudança de olhar sobre o missionário europeu e a sobre o índio Tupinambá do século XVI, tendo em vista que suas retraduções nos remeteram aos primórdios da colonização europeia da nação brasileira, nos proporcionando uma visão dos aspectos sociais e culturais presentes na época, através de uma ressignificação do discurso do índio Tupinambá do século XVI. 


\section{BIBLIOGRAFIA DE JEAN DE LERY}

LÉRY, Jean de. Histoire d'un voyage faict en la terre du Bresil : autrement dite Amérique. Genève: Antoine Chuppin, 1580 - 1 vol.

. Histoire d'un voyage faict en la terre du Brésil. Éditeur: Frank Lestringant. Librairie générale française, coll. « Les Classiques de Poche » (no 707), 1994

. Historia de uma viagem feita á terra do Brasil. Tradução de Monteiro Lobato. Rio de Janeiro: Companhia Editora Nacional, 1926. 285 p.

.Viagem à Terra do Brasil: tradução integral e notas de Sérgio Milliet segundo a edição de Paul Gaffarel com o Colóquio na língua brasílica e notas tupinológicas de Plínio Ayrosa. Belo Horizonte: Ed. Itatiaia, 2007. Coleção Reconquista do Brasil, v. 10. 303 p.

.História de uma viagem feita à terra do Brasil, também chamada América. Introdução de Carlos de Araujo Moreira Neto. Tradução de Maria Ignez Duque Estrada e Aryon Dall'Igna Rodrigues. Rio de Janeiro: Fundação Darcy Ribeiro, 2009. (Coleção Franceses no Brasil - Séculos xvi e xvii, v. 3). 290 p.

.L'Histoire mémorable du siège et de la famine de Sancerre (1573) : au lendemain de la Saint-Barthélémy. Présentation, édition et notes de Géralde Nakam. Généve: Slatkine Reprints, 2000.

\section{BIBLIOGRAFIA DE ARYON RODRIGUES}

RODRIGUES, Aryon D. Contribuição Linguística de Jean de Léry. In: História de uma viagem feita à terra do Brasil, também chamada América. Introdução de Carlos de Araujo Moreira Neto. Rio de Janeiro: Fundação Darcy Ribeiro, 2009. (Coleção Franceses no Brasil Séculos xvi e xvii, v. 3).

Estrutura do Tupinambá. In: RODRIGUES, A. D.; CABRAL, Ana Suelly Arruda Câmara; DUARTE, Fábio Bonfim (Org.). Línguas e Culturas Tupi. Campinas: Editora Curt Nimuendajú; Brasília: LALI/UnB, 2010. vol. 2, Cap. 1, p. 11-42.

Sobre as línguas indígenas e sua pesquisa no Brasil. São Paulo: Ciência e Cultura, vol. 57, n. 2, Abr/Jun 2005.

.Tarefas da lingüística no Brasil. Estudos Lingüísticos (Revista Brasileira de Lingüística Teórica e Aplicada), vol. 1, n. 1, p. 4-15. [Permalink:http://biblio.etnolinguistica.org/rodrigues_1966_tarefas]

. Línguas brasileiras: para o conhecimento das línguas indígenas. $1^{\mathrm{a}}$ ed. São Paulo: Edições Loyola, 1986. 134 p.

.Entrevista com prof. Dr. Emérito Aryon Dall'Igna Rodrigues. Brasília: Revista Traduzires, v. 1, $\mathrm{n}^{\mathrm{o}}$ 2, 2012. Entrevista concedida a Prof. ${ }^{\mathrm{a}}$ Dr. ${ }^{\mathrm{a}}$ Ana Helena Rossi.

.Entrevista com Aryon Dall'Igna Rodrigues. Entremeios: revista de estudos do discurso, v. 6, jan/2013. Entrevista concedida à Eni Puccinelli Orlandi, p. 1-31. 
.;CABRAL, Ana Suelly Arruda Câmara (Org.). Novos Estudos Sobre Línguas Indígenas. Brasília: Editora Universidade de Brasília, 2005. 244 p.

\section{BIBLIOGRAFIA CONSULTADA}

ABBEELE, Georges Van Den. Qu'est-ce qu'un truchement?: entre étranger et compatriote à l'époque des découvertes. In: L'Étranger tel qu'il (s')écrit, ed. Ana Clara Santos e José Domingues de Almeida (Biblioteca Digital): Faculdade de Letras, Universidade do Porto, 2014, pp. 189-196.

ALMEIDA, Rita Heloísa de. O diretório dos índios: um projeto de "civilização" no Brasil do século XVIII . Brasília: Editora UnB, 1997. Disponível em: 〈http://www.nacaomestica.org/diretorio_dos_indios.htm>. Acesso em: 19 jun. 2016.

ALVES, Regysane B. C.. A crítica de traduções na teoria e na prática: o caso da "Versão Brasileira". Rio de Janeiro, 2009, 118 f. Dissertação (Mestrado em Letras), pontifícia da Universidade Católica do Rio de Janeiro, 2009.

ANCHIETA, José de. Arte da gramática da língua mais usada na costa do Brasil. Edição fac-similar. São Paulo: Edições Loyola, 1990[1595].

AUBERT, F. H.. A tradução literal: impossibilidade, inadequação ou meta? Ilha do Desterro (UFSC), Florianópolis, 1987. pp. 13-20

AYROSA, Plínio. Nota Prévia. In: LÉRY, Jean de. Viagem à Terra do Brasil: tradução integral e notas de Sérgio Milliet segundo a edição de Paul Gaffarel com o Colóquio na língua brasílica e notas tupinológicas de Plínio Ayrosa. Belo Horizonte: Ed. Itatiaia, 2007. pp. 271273

AZEREDO, José Carlos de. Gramática Houaiss da Língua Portuguesa: redigida de acordo com a nova ortografia. São Paulo: Publifolha, 2014.

BARROS, Cândida. Os línguas e a gramática tupi no Brasil (século XVI). Cadernos Ciências Humanas do Museu Goeldi, n. 4, Belém, 1994.

.Um caso de política linguística: a questão do intérprete e do discurso religioso no Brasil colonial. Amerindia - Révue d'ethnolinguistique Amerindienne. 11: 69-77, Paris, 1986.

BARBOSA, Pe. A. Lemos. Curso de Tupi Antigo. Rio de Janeiro: Livraria São José, 1956. $473 \mathrm{p}$.

Pequeno vocabulário Tupi-Português. Rio de Janeiro: Livraria São José, 1951. 202 p.

$228 \mathrm{p}$.

Pequeno vocabulário Português - Tupi. Rio de Janeiro: Livraria São José, 1970. 
BATTISTI, Patrícia Stafusa Sala. A crítica de tradução em Antoine Berman: reflexo de uma concepção anti-etnocêntrica da tradução. 2000. 129f. Dissertação (Mestrado). Instituto de Estudos da Linguagem, Unicamp, Campinas, 2000.

BECHARA, Evanildo. Moderna Gramática Portuguesa. Rio de Janeiro: Editora Nova Fronteira, $37^{\mathrm{a}}$ edição revista, ampliada e atualizada conforme o novo Acordo Ortográfico, 2009.

BENJAMIN, Walter. A tarefa do tradutor. Trad.: Susana Kampff Lages. Belo Horizonte: FALE/UFMG, 2008, p. 66-81.

Sobre a linguagem em geral e sobre a linguagem dos homens. In: Walter Benjamin - Escritos sobre mito e linguagem (1915 - 1921). Organização, apresentação e notas de Jeanne-Marie Gagnebin; Trad. Susana Kampff Lages e Ernani Chaves. São Paulo: Editora 34; Duas Cidades, Coleção Espírito Crítico, 2011, p. 49-73.

BERMAN, Antoine. A tradução e a letra ou o Albergue do longínquo. Tradução de MarieHélène Catherine Torres, Mauri Furlan, Andréia Guerini. Rio de Janeiro: 7 letras/PGET, 2007.

Pour une critique des traductions: John Donne. Paris: Gallimard, 1995.

La retraduction comme espace de la traduction. Paris: Presses de la Sorbonne Nouvelle, Palimpsestes n. 4, p. 1-9, out.1990.

BESSA, Rita M. R. A língua francesa em roteiros de navegação do século XVI: Le grand routier de mer. Lettres Françaises, vol. 2, n. 12, p. 147-159, 2011.

BORGES, L. C., NUNES, J. H.. La langue générale et la grammatisation des langues indiennes. In: Langages, 32 eannée, ${ }^{\circ}$ 130, 1998. L'hyperlangue brésilliène. p. 52-67

BRISSET, A. Perspectivas culturais sobre a tradução. In: UNESCO, International Social Science Journal, v. 61, issue 199, pp. 69-81, march 2010. Tradução: Marcos Bagno, outubro de 2010.

Traduire pour s'inventer. Jeu: revue de théâtre, n. 56, sept. 1990, p. 55-60.

CÂMARA Jr., J. Mattoso. Introdução às Línguas Indígenas Brasileiras. 3. ed. Rio de Janeiro: Ao Livro Técnico, 1977.

Princípios de Lingüística Geral: como introdução aos Estudos Superiores da Língua Portuguesa. 4 ed. Rio de Janeiro: Livraria Acadêmica, 1989.

Dicionário de Lingüística e gramática: referente à língua portuguesa. 26. ed. Petrópolis, RJ: Vozes, 2007. 335 p.

Estrutura da língua portuguesa. 15. ed. Petrópolis: Vozes, 1985.

História da lingüistica. 7. ed. Petrópolis: Vozes, 2010. 238 p. 
CANCELA, Francisco. Recepção e tradução do diretório dos índios na antiga capitania de Porto Seguro: uma análise das instruções para o governo dos índios. História Social, n. $25,2^{\circ}$ semestre de 2013, pp. 44-70.

CARDOZO, Mauricio Mendonça. Solidão e encontro: prática e espaço da crítica de tradução literária. 2004. 174f. Tese (Doutorado). Faculdade de Filosofia, Letras e Ciências Humanas, USP: São Paulo, 2004.

CATFORD, John C.. Uma teoria linguística da tradução: um ensaio de língua aplicada; tradução do Centro de Especialização de Tradutores de Inglês do Instituto de Letras da PUC de Campinas. São Paulo: Cultrix; Campinas: PUC, 1980.

CERTEAU, Michel de. Etnografia: A oralidade ou o espaço do Outro: Léry. In: CERTEAU, Michel de. A escrita da história. Tradução de Maria de Lourdes Menezes. 2. ed. Rio de Janeiro: Forense Universitária, 1982. Cap. 5. p. 189-218.

CONFORTI, Marielle. Le subjonctif en français préclassique. Paris: Universidade ParisSorbonne, École Doctorale V, 2014. Tese de doutorado, Concepts et Langages Laboratoire de recherche : sens, texte, informatique, histoire.

DAHER, Andrea. Ecrire la langue indigène: la grammaire tupi et les catéchismes bilingues au Brésil (XVIe siècle). In: Mélanges de I'Ecole Française de Rome. Roma: MEFRIM, 1999. t. 111, pp. 231-250.

. A conversão do Tupinambá entre oralidade e escrita nos relatos franceses dos séculos XVI e XVII. Horizontes Antropológicos, Porto Alegre, ano 10, v. 22, p.67-92, jul. 2004.

DALBY, David; HAIR, P.E.H.. Le langaige du Bresil : a Tupi vocabulary of the 1540's. Transactions of the Philological Society, 1967.

D’ANGELIS, Wilmar R. Aryon das Línguas Rodrigues. Estudos da Lingua(gem), Vitória da Conquista, BA, v. 4, n. 2, p. 13-19, dez. 2006.

. Unificação x Diversificação ortográfica: Um dilema indígena ou de Linguistas?. In: RODRIGUES, A. D.; CABRAL, Ana Suelly Arruda Câmara (Org.). Novos Estudos Sobre Línguas Indígenas. Brasília: Editora Universidade de Brasília, 2005. Cap. 2. p. 23-33.

.Aryon Rodrigues: 70 anos dedicados à Linguística e às Línguas Indígenas. Revista D.E.L.T.A., n. 30 especial, 2014, p.503-512.

D'ÉVREUX, Yves. Voyage au nord du Brésil fait en 1613 et 1614 (Paris: $1^{\mathrm{er}}$ ed., 1615). Présentation et notes d'Hélène Clastres. Paris: Payot, 1985.

DUBOIS, Jean et al.. Dictionnaire Linguistique et des sciences du langage. Larousse: 1994, $514 \mathrm{p}$.

FLORIN, Sider. Realia in translation. In: Zlateva, Palma (ed.) Translation as Social Action: Russian and Bulgarian Perspectives. London: Routledge, 1993, pp. 122-128. 
FREIRE, J. R. B. Da Língua Geral ao Português: para uma história dos usos sociais das línguas na Amazônia. Rio de Janeiro, UERJ - Instituto de Letras, 2003. Tese de Doutorado em Literatura Comparada.

Da "fala boa" ao português na Amazônia brasileira. Amerindia - Revue d'Ethnolinguistique Amérindienne n. 8: pp. 39-83, Paris, 1983.

GAMBIER, Yves. La retraduction, retour et détour. Meta : journal des traducteurs / Meta: Translators' Journal, vol. 39, $\mathrm{n}^{\circ}$ 3, 1994, p. 413-417. Disponível em: <http://id.erudit.org/iderudit/002799ar>. Acesso em: 06 jun. 2016.

La retraduction: ambiguiités et défis. In: MONTI, E.; SCHNYDER, P. (orgs.) Autour de la retraduction. Paris: Orizons, 2012 p. 49-67.

GOHARD-RADENKOVIC, Aline. L'altérité » dans les récits de voyage. In: L'Homme et la société, n. 134, 1999. Littérature et sciences sociales. pp. 81-96.

HJELMSLEV, Louis. Prologomena to a theory of language. Translated by Francis J. Whitfield. Madison: University of Winsconsin Press, 1969.

HOUAISS, A. Dicionário eletrônico Houaiss da língua portuguesa. Chefe de equipe: João Carlos Passos Marinho. Rio de Janeiro: Objetiva, versão 3.0, 2009.

IGLESIAS, Juan A. G.. Estudio del género del diálogo en autores latinos tardíos. Universidad de Salamanca, 2001. Colección Vítor, Salamanca. 481 p.

KURY, Adriano da Gama. Emprego dos modos e tempos verbais. Cadernos do CNLF, vol. I, n. 1, 2002. Disponível em: <http://www.filologia.org.br/abf/volume1/numero1/06.htm>. Acesso em: 03 de out. 2016

LEITE, M. V.. Estrutura da Linguagem em Walter Benjamin. Revista Ética e Filosofia Política, v. 1, no. 12, p. 11-23, abr. 2010.

LEITE, Yonne \& FRANCHETTO, Bruna. "500 anos de línguas indígenas no Brasil". In: CARDOSO, Suzana A. M. et al. Quinhentos Anos de História Linguística do Brasil. Salvador: Secretaria da Cultura e Turismo do Estado da Bahia, 2006. pp. 15-62.

LÉPINETTE, Brigitte. La syntaxe dans le grammaires pour l'enseignement du français en Espagne au $\mathrm{XIX}^{\mathrm{e}}$ siècle. Documents pour l'histoire du français langue étrangère ou seconde, n. 29, 2002. pp. 26-93. Disponível em: <http://dhfles.revues.org/2292>. Acesso em: 25 nov. 2016.

LEPPIHALME, Ritva: Realia. In: Yves Gambier \& Luc van Doorslaer (eds): Handbook of Translation Studies. Amsterdam: John Benjamins, vol. 2, 2011, pp. 126-130.

LESTRINGANT, Frank. O canibal: grandeza e decadência. Tradução Mary Lucy Murray Del Priore. Brasília: Editora UnB, 1997. 285 p.

L'Expérience huguenote au Nouveau Monde (XVIe siècle). Genève: Librairie Droz, 1996. 394 p. (Travaux d'Humanisme et Renaissance). 
Le Huguenot et le sauvage: l'Amérique et la controverse coloniale, en France, au temps des guerres de religion. Genève: Librairie Droz, 3 ed., 2004. Collection Titre Courant. $632 \mathrm{p}$.

De Jean de Léry à Claude Lévi-Strauss: por uma arqueologia de Tristes Trópicos. Revista de Antropologia, São Paulo: USP, 2000, V. 43 nº 2.

É necessário expiar o renascimento? A abertura Antropológica do século XVI. Revista de História, $\mathrm{n}^{\mathrm{o}}$. 160, $1^{\circ}$ semestre de 2009, pp. 195-219.

A oficina do cosmógrafo, ou a imagem do mundo no Renascimento. Rio de Janeiro: Civilização Brasileira, 2009.

Entrevista com Frank Lestringant. Rio de Janeiro: Revista Topoi, v. 11, n. 20, jan.jun. 2010, p. 159-171. Entrevista concedida à Andrea Daher.

LÉVI-STRAUSS, Claude. O pensamento selvagem. Rio de Janeiro: Papirus, 2013.

MACHADO, Igor José de Reno. Cárcere público: processos de exotização entre imigrantes brasileiros no Porto. Portugal. Tese (Doutorado) em Ciências Sociais. Campinas, UNICAMP, 2003.

MALMKJAER, Kirsten: Language learning and translation. In: Yves Gambier \& Luc van Doorslaer (eds): Handbook of Translation Studies. Amsterdam: John Benjamins, vol. 1, 2010, pp. 186-189.

MARTINS, Selma Alas. O ensino da língua estrangeira: história e metodologia. Videtur (USP), v. 6, p. 45-56, 1999.

MATTOS, Thiago. Yves Gambier, teórico da retradução: uma releitura de Antoine Berman. Ronái: Revista de Estudos Clássicos e Tradutórios, vol. 2, nº 1, 2014, pp. 125 - 141, Juiz de Fora - MG (UFJF).

MATTOS, T.; FALEIROS, A. A noção de retradução nos estudos da tradução: um percurso teórico. Revista Letras Raras, vol. 3, n. 2, p. 35-57, 2014.

MAUPAS, Charles. Grammaire et syntaxe françoise : contenant reigles bein exactes et certaines de la prononciation, orthographe, construction et usage de notre langue (...) ([Reprod.]) par Charles Maupas, 1632. 3e. édition. 383 p.

MICHAELIS: Dicionário De Português Online. Disponível em: $<$ http://michaelis.uol.com.br/moderno/portugues/index.php?lingua=portuguesportugues\&palavra=muito>. Acesso em: 22 maio 2016.

MILLIET, Sérgio. Introdução. In: LÉRY, Jean de. Viagem à Terra do Brasil: tradução integral e notas de Sérgio Milliet segundo a edição de Paul Gaffarel com o Colóquio na língua brasílica e notas tupinológicas de Plínio Ayrosa. Belo Horizonte: Ed. Itatiaia, 2007. pp. 13-18.

NAVARRO, Eduardo de Almeida. Método Moderno de Tupi Antigo: A língua do Brasil dos primeiros séculos. 3. ed. São Paulo: Editora Global, 2006. 463 p. 
NOGUEIRA, B. C. de A. Ensaios de sciencia por diversos amadores. Rio de Janeiro, Brown \& Evaristo, 1876. vol. II. Disponível em: < http://www2.senado.leg.br/bdsf/item/id/242810>. Acesso em: 06 jun. 2016.

ORLANDI, Eni P.. Terra à vista. 2. ed. São Paulo/Campinas: Cortez/Unicamp, 2008, 260 p .

História das idéias linguísticas: Construção do saber metalinguístico e constituição da língua nacional. Organização de Eni p. Orlandi. São Paulo: Campinas, Editora Pontes; Mato Grosso: Cárceres, Unemat Editora, 2001. 300 p.

PAPAVERO, Nelson. Zoonímia tupi nos escritos quinhentistas europeus. São Paulo: NEHiLP/FFLCH/USP, vol. 3, 2014.

POMPA, Maria Cristina. Religião como tradução: missionários, Tupi e "Tapuia" no Brasil colonial. São Paulo: Campinas. Universidade Estadual de Campinas, Instituto de Filosofia e Ciências Humanas, 2001. 461 p. Tese de Doutorado.

RICHARDS, Jack C.; RODGERS, Theodore S. Approaches and Methods in Language Teaching. $15^{\mathrm{a}}$ ed. Cambridge: Cambridge University Press, 1999.

RODRIGUES, Cristina Carneiro. Tradução e diferença. Coleção Prismas, São Paulo: Editora UNESP, 2000.

SANTOS, Ilda Mendes dos. La découverte du Brésil : les premiers témoignages. Paris: Chandeigne, 2000, $192 \mathrm{p}$.

SAUSSURE, Ferdinand de. Curso de Linguística Geral. São Paulo: Cultrix, 2006.

ULHOA, Marcela. Aryon Rodrigues: "existem mais de 200 línguas e só se ensina português". Correio Braziliense, Brasília, Dez. 2012. Disponível em: <http://goo.gl/9XKLiC>. Acesso em: 02 abr. 2016.

VENUTI, Lawrence. Escândalos da tradução: por uma ética da diferença. São Paulo: EDUSC, 2003. 306 p.

WARTBURG, Walther Von. Évolution et structure de la langue française. 1962, 294 p.

WOLKMER, Antonio C. Cultura jurídica moderna, humanismo renascentista e reforma protestante. Revista Seqüência, Florianópolis, nº 50, jul. 2005, p. 9-27. 
APÊNDICE 


\section{APÊNDICE A}

Tabela 6 - Levantamento de dados sobre os diálogos do Colóquio

\begin{tabular}{|l|}
\hline 367 linhas de diálogo no total \\
\hline 240 enunciados sem tradução \\
\hline 127 enunciados que possuem a tradução literal do Tupinambá restaurado \\
\hline 30 enunciados que só contêm substantivos na tradução de Rodrigues \\
\hline 23 enunciados de Léry que só contêm substantivos \\
\hline
\end{tabular}

Fonte: CESAR, Janaína T. G., 2016

\section{APÊNDICE B}

Tabela 7 - Levantamento dos tempos verbais empregados nas três línguas analisadas no Colóquio

\begin{tabular}{|c|c|c|}
\hline TEMPOS VERBAIS EM FRANCÊS & TRADUÇÃO LITERAL FRA-PORT & $\begin{array}{c}\text { TRADUÇÃO DO TUPINAMBÁ RESTAURADO } \\
\text { PARA O PORTUGUÊS }\end{array}$ \\
\hline 76 verbos no indicatif présent & 73 verbos no presente do indicativo & 57 verbos no presente do indicativo \\
\hline 19 verbos no l'optatif présent & 21 verbos no presente do subjuntivo & 15 verbos no presente do subjuntivo \\
\hline 11 verbos no second preterit parfait compose & 12 verbos no pretérito perfeito do indicativo & 11 verbos no pretérito perfeito do indicativo \\
\hline 9 verbos no l'impératif & 9 verbos no imperativo afirmativo & 8 verbos no imperativo afirmativo \\
\hline 9 verbos no futur & 7 verbos no futuro do presente do indicativo & 6 verbos no futuro do presente do indicativo \\
\hline 3 verbos no second imparfait & 3 verbos no futuro do pretérito do indicativo & 1 verbo no futuro do pretérito do indicativo \\
\hline 1 verbo no plus-que-parfait de l'indicatif & 1 verbo no futuro composto do subjuntivo & \\
\hline
\end{tabular}




\begin{tabular}{|l|l|l|}
\hline 1 verbo no second plus-que-parfait (futur anterieur) & 1 verbo no pretérito imperfeito do subjuntivo & \\
\hline 1 verbo no imparfait de l'indicatif & $\begin{array}{l}1 \text { verbo no pretérito mais-que-perfeito composto do } \\
\text { indicativo }\end{array}$ & \multicolumn{1}{|c|}{ LEV VERBOS NO TOTAL } \\
\hline \multicolumn{2}{|c|}{ 130 VERBOS NO TOTAL } & \multicolumn{1}{|c|}{ 128 VERBOS NO TOTAL } \\
\hline \multicolumn{2}{|c|}{ LEVANTAMENTO DOS ENUNCIADOS } & 74 São compatíveis \\
\hline 119 correspondentes verbais & 9 Não são compatíveis \\
6 não correspondentes verbais & 45 Léry acréscimos \\
3 Verbos acrescidos por ARYON & 15 Aryon acréscimos \\
5 Verbos de LÉRY que não foram traduzidos por Aryon) & \\
\hline
\end{tabular}

Fonte: CESAR, Janaína T. G., 2016 


\section{ANEXO A - DECRETO DE VILLERS-COTTERÊTS PUBLICADO EM 1539}

\section{Articles 110 et 111 de l'ordonnance de Villers-Cotterêts}

110 - Et afin qu'il n'y ait cause de douter sur l'intelligence desdits arrests, nous voulons et ordonnons qu'ils soient faits et escrits si clairement, qu'il n'y ait ne puisse avoir aucune ambiguïté ou incertitude, ne lieu à demander interprétation.

111 - Et pour ce que telles choses sont souvent advenues sur l'intelligence des mots latins contenus esdits arrests, nous voulons d'ores en avant que tous arrests, ensemble toutes autres procédures, soient de nos cours souverains et subalternes et inférieures, soient de registres enquestes, contrats, commissions, sentences, testaments et autres quelconques actes et exploicts de justice, ou qui en dépendent, soient prononcez, enregistrez et délivrez aux parties en langaige maternelle françois et non autrement.

Fonte: Decreto de Villers-Cotterêts. Disponível em: <https://www.legifrance.gouv.fr/affichTexte.do?cidTexte=LEGITEXT000006070939>. Acesso em: 20 mai. 2016.

ANEXO B - ANOTAÇÕES NO COLÓQUIO ENTRE AS GENTES DO PAÍS SOBRE OS ASPECTOS DA GRAMÁTICA DA LÍNGUA TUPINAMBÁ FALADA NO SÉCULO XVI

\section{Página 264}

O que os gramáticos nomeiam e chamam verbo pode ser dito em nossa língua fala e na língua brasileira guengaue (nhe'éngába), que corresponde a dizer "falação" ou "maneira de dizer". E para conhecer um pouco dele daremos adiante uns exemplos.

\section{PRIMEIRAMENTE:}

SINGULAR INDICATIVO OU DEMONSTRATIVO:

Aicó (aicó), eu estou. Ererico (ereicó), você está. Oico (oicó), ele está.

PLURAL:

Oroico (oroicó), nós estamos. Peico (peicó), vocês estão.

Auraèo iço (auãaé oicó), eles estão.

As terceiras pessoas do singular e plural são semelhantes, salvo que é preciso acrescentar ao plural an ae (auãaé), pronome que significa eles, como se vê.

No tempo passado imperfeito e não inteiramente acabado, pois a gente pode ser ainda o que a gente era então, resolve-se pelo advérbio aquoémè (acuéime), isto é, naquele tempo.

SINGULAR:

Aico-aquoémè (aicó acuéime), eu estava então. Ereico-aquoémé (ereicó acuéime), você estava então. Oico aquoèmè (oicó acuéime), ele estava então. 


\begin{abstract}
PLURAL IMPERFEITO
Oroico aquoémè (oroicó acuéime), nós estávamos então. Peico aquoémé (peicó acuéime), vocês estavam então. Aurae-oico-aquoémè (auãaé oicó acuéime), eles estavam então.
\end{abstract}

\title{
Página 265
}

\section{PARA O TEMPO PERFEITAMENTE PASSADO E COMPLETAMENTE ACABADO:}

\section{SINGULAR:}

Tomar-se-á o verbo Oico (oicó) como acima e acrescentar-se-lhe-á este advérbio Aquoèmenè (acuéime bé), que equivale a dizer "no tempo doe outrora" e perfeitamente passado, sem nenhuma esperança de ser mais do jeito que era naquele tempo.

\section{EXEMPLO:}

Assavoussou-gatou-aquoémené (açauçúcatú acuéime bé), eu o amei perfeitamente naquele tempo, Quovenén-gatou-tègn-e (co'ý a'ángatú tenhé), mas agora de jeito nenhum; como dizendo: ele devia corresponder à minha amizade, pois não se pode voltar a esse tempo.

\section{PARA O TEMPO POR VIR, QUE CHAMAMOS FUTURO}

Aico-irén (aicó Irã), eu estarei no futuro. E fazendo-se seguir das outras pessoas como acima, tanto no singular como no plural.

PARA O MANDADOR, QUE CHAMAMOS IMPERATIVO:

Oico (eicó), esteja você. Toico (toicó), que ele esteja.

PLURAL:

Toroico (toroicó), que nós estejamos. Tapeico (tapeicó), que vocês estejam. Aurae toico (auãé toicó), que eles estejam. E, para o futuro, basta acrescentar Iren (Irã), como acima. E dando ordem para o presente, deve-se dizer Taugé (taujé), que quer dizer "agora mesmo".

PARA O DESEJO E AFEIÇÃO QUE SE TEM COM RESPEITO A ALGUMA COISA, A QUE CHAMAMOS OPTATIVO:

Aico-mo-mèn (aicómo mã), ó como eu estaria de bom grado; continuando do mesmo modo que acima.

Para a coisa que se quer reunir junto, que chamamos conjuntivo, resolve-se por um advérbio Iron (irũmo), que significa como o que se quer juntar.

Exemplo: taico-de-iron (taicó ndé irũmo), que eu esteja com você.

\section{O PARTICÍPIO TIRADO DESTE VERBO:}

Chè recoruré (xé recóreme), estando eu.

Esse particípio não pode ser entendido só, sem que lhe acrescentemos o pronome de (ndé), ahe (ahë) e aé (a'ë), e analogamente o plural: Oreé (oré), pèe (pe'ë), an-aé (auãaé). 
O termo indefinido deste verbo pode ser tomado por um infinitivo, mas eles não fazem uso frequente dele.

\section{DECLINAÇÃO DO VERBO AIOÜT.}

Exemplo do indicativo ou demonstrativo no tempo presente; embora soe duplo em nossa língua, é que soa também como passado:

NÚMERO SINGULAR:

Aiout (ajúr), eu venho ou eu vim.

Ereiout (erejúr), você vem ou veio.

O-out (oúr), ele vem ou veio.

NÚMERO PLURAL:

Oro-iout (orojúr), nós vimos ou viemos.

An-ae-o-out (auãaé oúr), eles vêm ou vieram.

Para os outros tempos, basta tomar só os advérbios declarados adiante, pois nenhum verbo se declina de outro modo que não se resolva por um advérbio, tanto no presente, pretérito imperfeito, mais-que-perfeito indefinido, quanto no futuro ou tempo por vir.

EXEMPLO DE PRETÉRITO IMPERFEITO E QUE NÃO ESTÁ INTEIRAMENTE ACABADO:

Aiout-aguoème (ajúr acuéime), eu vinha então.

EXEMPLO DE PRETÉRITO PERFEITO E INTEIRAMENTE ACABADO:

Aiout-aguoèmènè (ajúr erima'é bé), há muito tempo que eu vim.

Aiout-dimaè-nè (ajúr erima'é bé), há muito tempo que eu vim.

EXEMPLO DO FUTURO OU TEMPO POR VIR:

Aiout-Iran-nè (ajúr irãne), eu virei algum dia; também se pode dizer Iran (Irã), sem

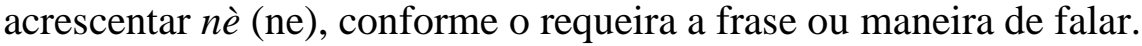

Deve-se notar que, ao acrescentar os advérbios, convém repetir as pessoas exatamente como no presente do indicativo ou demonstrativo.

EXEMPLO DO IMPERATIVO OU MANDADOR:

NÚMERO SINGULAR:

Eori (ejórí), venha (você).

Eyot (ejór), venha (você).

SÓ HÁ A SEGUNDA PESSOA, POIS NESTA LÍNGUA NÃO SE PODE MANDAR A 
TERCEIRA PESSOA, QUE NÃO SE VÊ, MAS PODE-SE DIZER:

Página 267

Emo-out (eimoúr), faça-o vir.

Pe-ori (pejórí), venham (vocês).

Pe-iot (pejór), venham (vocês).

Os sons escritos eiot e pe-iot têm o mesmo significado, mas o primeiro, eiot, é mais próprio para dizer entre pessoas, ao passo que o último, pe-iot, é usado comumente para chamar os animais e aves que eles criam.

EXEMPLO DO OPTATIVO, QUE PARECE COMANDAR PEDINDO OU MANDANDO. SINGULAR:

Aiout-mo (ajúrmo), eu viria ou teria vindo de bom grado, seguindo as pessoas como na declinação do indicativo. Ele tem um tempo futuro, acrescentando o advérbio, como acima.

\section{EXEMPLO DE CONJUNTIVO:}

Ta-iout (tajúr), que eu venha.

Mas, para melhor realizar o significado, acrescenta-se esta palavra Nein (ne'í), que é um advérbio para exortar, mandar, incitar ou pedir.

Eu não conheço nenhum indicativo (leia-se: infinitivo), neste verbo, mas dele deriva um particípio:

Touume (túreme), vindo.

\section{EXEMPLO:}

Ché-rourmè-Assoua-nitin. Chè remièreco-pouére. (xé rúreme açobaití xé remie-recópuéra). Vindo, encontrei o que eu tinha guardado.

Senoyt-pe (cebo'ípéb), sanguessuga.

Inuby-a (mimby), cornetas de madeira que os selvagens tocam.

Fonte: LÉRY, Jean de. Colóquio entre as gentes do país. In: História de uma viagem feita à terra do Brasil, também chamada América. Introdução de Carlos de Araujo Moreira Neto. Tradução de Maria Ignez Duque Estrada. Rio de Janeiro: Fundação Darcy Ribeiro, 2009. (Coleção Franceses no Brasil - Séculos xvi e xvii, v. 3). 